\title{
WestVirginiaUniversity
}

THE RESEARCH REPOSITORY @ WVU

Graduate Theses, Dissertations, and Problem Reports

2015

\section{Word Play: Modernist Women and Performative Writing}

Kathryn Ridinger Smorul

Follow this and additional works at: https://researchrepository.wvu.edu/etd

\section{Recommended Citation}

Smorul, Kathryn Ridinger, "Word Play: Modernist Women and Performative Writing" (2015). Graduate Theses, Dissertations, and Problem Reports. 6677.

https://researchrepository.wvu.edu/etd/6677

This Dissertation is protected by copyright and/or related rights. It has been brought to you by the The Research Repository @ WVU with permission from the rights-holder(s). You are free to use this Dissertation in any way that is permitted by the copyright and related rights legislation that applies to your use. For other uses you must obtain permission from the rights-holder(s) directly, unless additional rights are indicated by a Creative Commons license in the record and/ or on the work itself. This Dissertation has been accepted for inclusion in WVU Graduate Theses, Dissertations, and Problem Reports collection by an authorized administrator of The Research Repository @ WVU.

For more information, please contact researchrepository@mail.wvu.edu. 


\title{
Word Play: Modernist Women and Performative Writing
}

\author{
Kathryn Ridinger Smorul \\ Dissertation submitted \\ to the Eberly College of Arts and Sciences \\ at West Virginia University \\ in partial fulfillment of the requirements for the degree of \\ Doctor of Philosophy in \\ English
}
Kathleen Ryan, Ph.D., Chair
Dennis Allen, Ph.D.
Ryan Claycomb, Ph.D.
Juliana Spahr, Ph.D.
Lisa Weihman, Ph.D.
Department of English

Morgantown, West Virginia

2015

Keywords: American Modernism; Performance Studies; Performative Writing; Activism Copyright 2015 Kathryn Ridinger Smorul 


\title{
ABSTRACT \\ Word Play: Modernist Women and Performative Writing
}

\author{
Kathryn Ridinger Smorul
}

In Word Play: Modernist Women and Performative Writing I read modernist literary texts informed by theories about theatre, performance, and art. Exploring lesser-known works of Djuna Barnes, Gwendolyn Bennett, Edna St. Vincent Millay, and Mina Loy, I combine literary analysis and performance studies to discover how modernist texts "talk back" to performance theories. Performance studies, of course, is an inter-discipline that includes anthropology, sociology, performing arts, and literary theory. Modernist authors, influenced as they often are by art, performance, and ritual, incorporate these interdisciplinary interests into a writing practice, specifically performative writing.

Performative writing is not so much a matter of style and form as a discursive, rhetorical practice. It presents textual moments that invoke performance and is grounded in the corporality of the body, calling attention to physical bodies in relation and movement. Because performative writing contains a rhetoric of potential action, it can have real social and political consequences. It stages a particular type of encounter between textuality and social realities, a relationship that appears in each of the primary texts I explore in this project. The work of these women is an active response to and reworking of social and political issues, and it acknowledges the complex relationship between history/politics and art/aesthetic form. I understand this labor as a modernist performance.

I do not attempt to define or demonstrate the most illustrative examples of performative writing; nor do I aim to lay out a conclusive and complete definition. Rather, I am interested in discovering how performative writing acts in the world and what effects it has. I lead with the writers themselves and map several trajectories of performative writing through these writers and their work. I chose these writers because they employ similar rhetorical strategies and have shared stylistic practices. I set the stage with Barnes to show the relation between physical violence and rhetorical violence; Bennett's performativity involves breaking enforced invisibility and silence and uniting a community; Millay offers a metatheatrical performance that positions human agency against cycles of violence throughout history; and Loy gives a subjective account of the trauma of gender performance. Each chapter explores a different kind of violence and intervenes in that violence, offering commentary and critique in "highbrow" as well as "lowbrow" genres. My project demonstrates the ways in which the practice of performative writing can inform and expand our study of modernisms, genre, and gender. 


\section{Acknowledgements}

I am indebted to a number of people who provided me with support and encouragement throughout the many stages of this project. I could not have asked for a better mentor and advisor than Katy Ryan; in her intelligence, wisdom, grace, and openness she is the model of a true academic. I also owe a great debt to each of my readers, who were actively involved in my process. Ryan Claycomb was instrumental in helping me form and articulate the foundational concepts of this project. Dennis Allen pulled me out of murky waters many times with reassurance and humor. Lisa Weihman provided kind and insightful feedback that helped me to clarify my argument. My outside reader Juliana Spahr was invaluable as a theorist and practitioner of performative writing. Special thanks to the WVU English Department and the Eberly School of Arts and Sciences for providing the dissertation fellowship. I am deeply indebted to all of my professors and mentors at WVU and Duquesne University who served as personal and professional role models. To my family, especially my parents John and Dottie Ridinger, who instilled in me the value of education and whose love and support are unfailing. To Ken, Louise, and Mary Veselicky who taught me how to be a proud Mountaineer and generously offered me a place to live when I began the Ph.D. program. And finally, to my husband Mark, for his ongoing encouragement, patience, and support. 


\section{Table of Contents}

Introduction

Chapter 1

Of Marionettes, Boxers, and Suffragettes: Exploring the Mor(t)al Body in Djuna Barnes's Performative Journalism

Chapter 2

"Literary Chit-chat and Artistic What-not": Gwendolyn Bennett's "The Ebony Flute" and African American Expressive Culture

Chapter 3

"Whadda you think this is — a dress rehearsal?": Performance and Metatheatricality in Edna St. Vincent Millay's Aria da Capo

\section{Chapter 4}

Mina Loy's Identity Performance: Autobiography and the Birth of the Poet in "Anglo-Mongrels and the Rose"

Epilogue

The Legacy of Performative Writing: From Modernism to Contemporary Lyrical/Critical Writing 
Introduction

Word Play: Modernist Women and Performative Writing

In 1916, Mina Loy left her family behind in Florence and sailed to New York, making her grand American debut. Loy was already well-known among New York modernists for her scandalous poetry collection Songs to Joannes, which had appeared the previous year in the new little magazine Others, edited by Alfred Kreymborg. Her work was already published in Camera Work and Trend. In that same year, Djuna Barnes was an established journalist doing freelance work for several New York magazines and newspapers, including the New York Tribune, Bruno's Weekly, Pearson's Magazine, and the New York Morning Telegraph. By the 1920's both Barnes and Greenwich Village poet and actress Edna St. Vincent Millay were publishing work in Vanity Fair. And across town in Harlem, Gwendolyn Bennett's poetry and visual art was appearing in Crisis, Opportunity, and Fire!! These modernist writers all became known by publishing their work in newspapers and little magazines, which abounded in New York in the early $20^{\text {th }}$ century. These publications established networks of affiliation between writers and artists both locally and internationally. Loy had American publishing contacts well before she set foot in the United States, and in her literary news column in Opportunity Bennett reached out to an international black community. These literary communities often formed in opposition to the mainstream and were crucial in inspiring a sense of belonging among the avant-garde and providing opportunities for professional advancement.

Each of the women in my study identified with artistic countercultures and defined themselves by them: Barnes and Loy made appearances at Natalie Barney's salon, Bennett was a major figure in the New Negro Renaissance in Harlem and a regular at Georgia Douglas 
Johnson's salon, and Millay is associated with the Greenwich Village bohemians. Barnes, Loy, and Millay all wrote or acted for the Provincetown Players. Nina Miller explains that "subcultural affiliation" is "a key mediating horizon for many writers of the modern period" (6). She discusses the formation of "artistic subcultures" in New York, particularly those centered around Greenwich Village and Harlem: “An urban formation, and, by definition, oppositional, artistic subculture sets itself apart from the dominant bourgeois order in a posture of critique, distance, or at least, ambivalence. More than a position, the subcultural posture marks a certain kind of person — quintessentially modern, defining herself in the paradoxical space of the insider (to the subculture) / outsider (to the mainstream)" (6). This simultaneous "insider/outsider" status provided the inspiration and the impetus for these writers; while their work may have been misunderstood or disparaged by mainstream culture, they found a sense of encouragement and acceptance within their own communities. The writers and artists who participated in these subcultures simultaneously defined and were defined by the artistic ethos of the group. Notably, many of the avant-garde communities in New York in the early twentieth century produced work that was socially and politically activist and had a vexed relationship with the purely aesthetic and formal aspects of "high modernism."

\section{Modernisms and Gender}

Barnes, Bennett, Millay, and Loy each have a complex and tenuous relation to modernism, which may be why their work was ignored for a time in the critical literature and has been resurrected more recently. They were all well-known writers in their own time, but their popularity waxed and waned over the decades after their deaths. Except for Millay, who died tragically in her prime, these women became recluses in their old age and died in near obscurity. For all of them, but especially for Bennett, there is still much recovery work to be done. My 
project aims to bring the important work of these women to light, especially the lesser known bodies of work of writers like Barnes and Loy, who, since the 1980s and 1990s, are finally being recognized for their contributions to modernism.

Critics have noted the difficulty of placing these women and their work in terms of literary historical periodization. For instance, Louis Kannenstine describes Barnes's work as "transitional": "As Miss Barnes's art can be seen as both related to its time and yet apart from it, it can be concluded that she is a transitional writer whose purpose was to get out of the mainstream and participate in a great tradition, and who now takes a place in her own time between the early innovators of this century and the later generations of experimental writers" (xvii). Given her association with an earlier sentimentalist tradition and her use of nineteenthcentury poetic form, Millay is an uneasy modernist as well. Although the content of her poetry is modern and subversive, for the most part Millay does not engage in the formal experimentation common to modernist writers. ${ }^{1}$ Bennett was a well-known figure during the Harlem Renaissance, but much of her work has fallen into obscurity in a field dominated by towering figures such as Langston Hughes, Claude McKay, and Countee Cullen. Perhaps because she never published a poetry volume or novel of her own, Bennett is not as known as other women such as Jessie Fauset and Zora Neale Hurston, who have benefitted from recovery work on female writers and artists of the Harlem Renaissance. Of all these writers, Loy is the oldest and her work fits most easily into a high modernist tradition. She was a writer, a painter, a found artist, an inventor, and a lampshade designer. Although she was considered by Pound to be a quintessential American modernist poet she was actually born in England and did not identify herself as a poet. Loy defied categorization by carefully spinning a web of mystery and intrigue around herself. There 
is a story that some of her modernist contemporaries who had never met her wondered if "Mina Loy" was a real person or merely an idea.

My dissertation explores the limits of modernism insofar as the writers I feature experience disillusionment with what modernism cannot do. These writers expose the challenge of dwelling between the formalist experimentation of high modernism and the social and political concerns of the next generation that was more engaged with culture industries and mass entertainment. Each of the writers in my study combines their social and political consciousness with a serious interest in the rhetorical exigencies of genre and formal experimentation. Tyrus Miller critiques early modernism's aesthetic ideology, which includes “the heroic subjectivity of the innovating artist; the organic convergence of form and content in a symbolic unity set down by the artist on paper, on canvas, in stone; the exhibition of stylistic mastery as a criterion of value; the belief in an underlying mythic or aesthetic order to history; and the possibility of redeeming tradition through its transfiguration into art" (45). For Miller, late modernism calls these earlier precepts into question by introducing a "new configuration of self" which the disoriented modern subject experiences when the separation of subject and object begins to break down, redefining the relationship between inner life and the outer world (45). The work of the writers I feature registers this shift in values and perspective and attests to the disillusionment and disorientation experienced by modern subjects. Loy particularly calls the "heroic subjectivity" of the artist and narrator into question as she presents a poetic self that is fragmented and multiple.

The advent of New Modernist Studies expanded the scope of modernism. In their 2008 article "The New Modernist Studies," Douglas Mao and Rebecca L. Walkowitz describe this expansion in temporal, spatial, and vertical terms; they propose loosening rigid boundaries 
involving time period and geography as well as genre, specifically the relationship between high art and popular culture (737-738). However, the usefulness of this "new" approach is contested for a number of reasons. I will explore two different substantive critiques of New Modernist Studies that have a direct bearing on my project. First, although this approach focuses on expansion, it still excludes or de-emphasizes facets that many critics consider central to the study of modernism. Anne E. Fernald is concerned that Mao and Walkowitz list gender as only one of a number of possible areas of interest within modernist studies. She argues that this approach defines gender as an "add-on" rather than a fundamental aspect of our understanding of ourselves and the world:

In fact, for over twenty-five years, scholars, both feminist and non-feminist, have acknowledged gender as a constitutive category of modernism. The study of transnationalism and media have undoubtedly transformed our conception of modernisms, and yet, if our stated interest is to expand the field to writers whose work has been heretofore seen as bad or lacking examples of true or high modernism, if we have an interest in mass culture, if we want to de-center our gaze so as to encompass all the globe, the first place we should look is to women readers and writers. (230)

Fernald points out that if we are to extend the study of modernism to the marginal work of undervalued writers and artists in the ways the New Modernism proposes, female writers and artists as well as gender relations should be at the center of these discussions. My dissertation emphasizes the importance of gender and gender performance to the study of modernism. Each chapter discusses a female modernist writer who has an obvious commitment to gender analysis at a time when women were still working to claim a space for themselves in the public sphere. 
Barnes appears as the daring girl stunt reporter; Bennett claims an authoritative voice in the male-dominated Harlem Renaissance; Millay exposes the specter of violence in male/female relations; and Loy vilifies harmful gender conditioning in the domestic sphere. The work of each of these women easily fits into other dimensions of New Modernist Studies-some were marginal figures writing toward a popular audience; some wrote in lowbrow genres or consumable media; and all engaged in some way with mass culture and defied the tenets of high modernism. While the New Modernist Studies has been crucial in expanding the breadth and depth of modernist studies generally, the realities of the historical period demand a more focused attention on the study of gender.

Other critics are concerned not so much with what the New Modernism deemphasizes, but with its disciplinary approach and methodology. Charles Altieri points out that in focusing on subversive works that resist high modernist values and formalism we may overlook foundational questions about the relationship between art and politics:

When we are eager to ally art with political change, we are likely to rely on interpretive languages or research agendas that themselves are organized in terms of questions emphasizing historical phases of quests for justice and equality. These research agendas from fields like sociology and history directly address the social world without any detour into what might make something art and solicit different kinds of relationships to the individuals experiencing it. Therefore, we also tend to ignore those historical practices and values that take their authority from the art they generate and the capacities they develop for having satisfying experiences of the art as art. (770) 
My project delves deep into the political aspects of these modernist works, including such historical issues as suffragism, racism, war, and nationalism. There is certainly a great value in the kinds of interdisciplinary projects Altieri mentions, projects that may combine literary and art criticism with history, sociology, political science, or philosophy. Yet I share Altieri's concern that something is lost when the focus of these studies is solely on historical and political context to the exclusion of the art object and aesthetic form. Ideally, in an analysis of art or literature these perspectives should inform and complement each other. My project focuses first and foremost on individuals, on the women themselves, their relationship to their work, and the effect that work has on their political and social environment. Insofar as a work of art or literature can inspire social engagement or demand change, I am interested in discovering how performative writing acts in the world and what effects it has. Each of these writers utilizes performative writing to accomplish certain goals: to expose physical and rhetorical gender violence, to give voice and agency to the silenced and the marginalized, and to unite and celebrate certain subcultures or communities. I study the work of these women as an active response to and reworking of social and political issues, acknowledging the complex relationship between history/politics and art/aesthetic form. And I understand this labor as a modernist performance.

How does modernism engage or fail to engage with social, economic, political, and working-class concerns? We immediately have to ask, "Which modernism"? In his analysis of the cultural front Michael Denning defines modernism as "the expression of the dreams, discontents, and cultural contradictions of the disaffected young people of the predominantly Anglo bourgeoisie as they came to grips with the changes in the corporate economy and the changes in proper sexuality and gender roles, with the new imperialism, with the 'foreign hordes' 
of immigrant workers" (28). Denning notes that it was this modernist "crisis" that led to the age of the CIO, as "unions were built by the children of the modernist migration" (29). Most importantly, "The young artists and intellectuals of the age of the CIO inherited the mantle of modernism $[\ldots]$ but $[\ldots]$ they sought to create a new social modernism, a 'revolutionary symbolism"” (29). I argue that the modernist writers in my project move beyond a focus on form and aesthetics and begin to pave the way for this "social modernism." Thus, they dwell in a kind of interstitial space between modernist formalism and social activism.

While these women did not shy away from writing about social realities, Barnes and Loy were reluctant to align themselves with certain organized political movements, while Millay and Bennett did so openly. Although Barnes was willingly force-fed in prison to draw attention to the plight of the suffragettes, she did not openly support suffragism and even mocked the suffragettes' methods in some of her other works. Her article on force-feeding functions more as an exposé of a human rights violation than an openly political statement. While Loy wrote extensively about gender relations, especially in the context of Italian Futurism, she was careful not to align herself with the organized feminist movement in the United States. Millay and Bennett, however, both involved themselves in political causes, despite that fact that their participation opened them to criticism. Millay was pictured marching for Sacco and Vanzetti and was disparaged by critics for her openly anti-war poetry. Later in her career Bennett worked for the Harlem Arts Guild and the New York City Works Progress Administration Federal Arts Project. As a result of her political involvement Bennett was investigated several times by the FBI for alleged communist activity, although she was never convicted.

\section{Two Views into Modernism: Rhetorical and Performative}


A boundary is more like a membrane than a wall.

-Dwight Conquergood, "Performance Studies"

The primary texts I have chosen for this project include genres with which these writers are not usually associated; some even tried to distance themselves from them. Well-known for her later novels such as Nightwood, Barnes herself disparaged her early journalism, and it has been largely ignored in the critical literature. However, some have pointed out that the demands of stunt journalism and the challenge of writing to a popular audience greatly influenced her later work. ${ }^{2}$ When Bennett is discussed she is most often remembered as a poet and editor, but her literary column "The Ebony Flute," which appeared in Opportunity, highlighted her status not only as a columnist and critic but an insider with intimate knowledge of people and events in her community. Both Barnes's articles in New York magazines and newspapers and Bennett's literary column are periodical genres, which appear in serial format and require an author to use rhetorical strategies to assess and appeal to his or her specific audience.

Millay is best known for her collections of poetry such as Renascence, A Few Figs from Thistles, and The Ballad of the Harp-Weaver, for which she was awarded a Pulitzer Prize. However, Millay was also a playwright, and she wrote her first play while in college at Vassar. Her anti-war drama Aria da Capo received favorable reviews when it was first performed, but it is now one of her more obscure works and some have labeled it propagandistic. Although Loy expressed herself in a variety of literary genres and artistic media, she only wrote one autobiographical epic poem, “Anglo-Mongrels and the Rose." The long poem was certainly not unheard of in the era of Eliot's Wasteland, and Melita Schaum notes that a few female authors tried to reclaim the genre: "Often violently polemical, radically confessional, encoded in unconventional poetic language, the 'sub-genre' of the female autobiographical epic stands as a 
fascinating phenomenon of literary and social milieu of the early $20^{\text {th }}$ century" $(255-56)$. The anti-war drama and the epic poem are both genres that were being actively reworked and reassessed for their utility in the modernist era.

Each of these writers recognized the importance of genre and rhetorical situations. In her exploration of genre as social action, Carolyn Miller claims that "a rhetorically sound definition of genre must be centered not on the substance or the form of discourse but on the action it is used to accomplish" (151). Thus, the study of genre should be audience-focused and should explore the purpose or effects of writing. For Miller, "A genre is a rhetorical means for mediating private intentions and social exigence; it motivates by connecting the private with the public, the singular with the recurrent" (163). Genres are not merely social or institutional contracts created for mutual understanding; they work to establish patterns for communication between individuals and their communities. ${ }^{3}$ By exploring the social and rhetorical actions associated with certain genres, we can begin to see how form and style function and how following, bending, or disrupting the conventions of certain genres can communicate implicit messages to the audience. Each of the women in my study consciously use genre as a rhetorical tool in their social and political critiques. For instance, Barnes utilizes her popular reporting medium to perform gender critique, while Millay combines theatrical forms in a political protest drama to highlight the physical, psychological, and emotional casualties of war.

Studying the rhetorical contexts of modernist texts and the way they engage their audiences also leads to questions about their performative capabilities. I utilize an interdisciplinary approach in my project, applying the work of contemporary performance theorists to modernist texts. The value of interdisciplinarity lies not just in experimentation or collaboration between departments within the university (i.e. literature, art, creative writing), but 
in questioning or blurring generic and disciplinary boundaries, which can have real political and social effects outside as well as inside the academy. Dwight Conquergood explores the ways in which performance studies breaks down disciplinary categories: "Performance studies struggles to open the space between analysis and action, and to pull the pin on the binary opposition between theory and practice. This embrace of different ways of knowing is radical because it cuts to the root of how knowledge is organized in the academy" (311-312). Conquergood refers to the "dominant way of knowing in the academy," which is based on "empirical observation" and "critical analysis" and relies on distance from the observed (312). But the performative mode relies on "another way of knowing that is grounded in active, intimate, hands-on participation and personal connection" (312). This approach is practice-based and grounded in the body. I am interested in the ways in which a performative approach can be utilized in textual analysis, particularly in texts that incorporate everyday performativity.

Many performance theorists agree that the modern notion of performativity has its roots in speech-act theory, specifically in J. L. Austin's seminal essay "How to Do Things with Words," in which he distinguishes between constative statements and performative utterances. The purpose of constatives is to describe, and they can be proven to be true or false, while performatives have the power to incite action or change a social reality. In his essay, Austin offers marrying, naming, bequeathing, and betting as examples of performative utterances (5). Certain post-structuralist theorists such as Judith Butler continue to draw upon speech-act theory. Sara Salih summarizes Butler's complex notion of gender performativity in this way: "Gender is not something one $i s$, it is something that one does, an act, or more precisely, a sequence of acts, a verb rather than a noun, a 'doing' rather than a 'being”' (55). In Gender Trouble, Butler asserts, "There is no gender identity behind the expressions of gender; that identity is 
performatively constituted by the very 'expressions' that are said to be its results" (25). If gender is constructed in this way then it is inherently performative; certain repeated acts constitute gender. Elin Diamond explains the relationship between performance and performativity: "Performance...is the site in which performativity materializes in concentrated form," where we can study and examine the "dissimulated conventions of which acts are mere repetitions" (47). Performance, then, opens a space where we can investigate how identities are constructed and performed.

Interestingly, Austin is careful to distinguish speech-act theory from theatrical speech. In narrating the complex history of performance studies as a discipline, Shannon Jackson characterizes it as "the integration of theatrical and oral/rhetorical traditions" (10). Jackson notes that performance studies and theater "might be usefully understood within a shared, if internally discontinuous, institutional history" (11). Undoubtedly the two fields have drawn much from each other, especially in recent years. Andrew Parker and Eve Kosofsky Sedgwick attest to the recent broadening of theater studies to "embrace a myriad of performance practices, ranging from stage to festival and everything in between: film, photography, television, computer simulation, music, 'performance art,' political demonstrations, healthcare, cooking, fashion, shamanistic ritual... (2). Although theater studies may incorporate a wider variety of social performances, theorists such as Diamond call attention to the fundamental methodological differences between the two fields:

Theater spectators are encouraged in pleasurable narrativity: prompted to identify with the psychological conflicts of individual subjects, to respond to the lure of suspense, reversal and deferral, to decode gestural and spectacular effects. Performance, on the other hand, dismantles textual authority, illusionism, and the 
canonical actor in favor of the polymorphous thinking body of the performer, a sexual, permeable, tactile body...that scourges audience narrativity (84)

Performance disrupts and questions traditional mimetic representation and relies on the corporeal body to tell a story. Conquergood places this "story," which is "practical, embodied, and popular," in direct opposition to the "map," which is "official, objective, and abstract" (311), again referencing different ways of knowing. When theater audiences engage in "pleasurable narrativity" they are participating in an established domain of knowledge which is characterized by representation, imitation, identification, and illusion. In contrast, performance takes a more active approach, working to demolish established patterns of interaction between actor and audience, writer and reader. An example of this kind of approach can be found in feminist performance theory, which combines theory and practice, working subversively against the dominant culture to enact social change.

My method involves reading modernist literary texts informed by theories about theatre, performance, and art. In combining literary analysis and performance studies in my dissertation, my main interest is in exploring how modernist texts "talk back" to performance theories. More specifically, can the roots of performance studies be found in modernist performative practices? Performance studies, of course, is an inter-discipline that includes anthropology, sociology, performing arts, and literary theory. Modernist authors, influenced as they often are by art, performance, and ritual, incorporate these interdisciplinary interests into a writing practice, specifically performative writing.

\section{Performative Writing and the Body}


Performative is the power of a narrative to make something happen as opposed to its power to give, or appear to give, knowledge.

$$
\text { -J. Hillis Miller, "Narrative" }
$$

Performative writing is not a genre or a fixed form but a way of describing what some good writing does.

\section{-Della Pollock, "Performing Writing"}

One can argue that all writing is inherently performative, but performative writing presents textual moments that invoke performance; it calls attention to writing itself as an act and an action; and, most importantly, as a visible yet constantly disappearing text, performative writing echoes the ephemerality of live performance. Performative writing is grounded in the corporality of the body and it calls attention to physical bodies in relation and movement. As a point of intersection with modernist writing, performative writing emphasizes the process and labor of authorship and struggles with the inadequacy of language to express that which is fleeting and ephemeral. As perhaps the primary theorist and advocate of performative writing, Peggy Phelan explores its forms and methods as well as its consequences. She notes that performative writing is "the act of writing toward disappearance, rather than the act of writing towards preservation" (Unmarked 148). In Mourning Sex, Phelan emphasizes that attempting to preserve the performance event through writing should be avoided; rather, we should explore "the possibility that something substantial can be made from the outline left after the body has disappeared" (3). Without directly representing the performance it references, performative writing should "enact the affective force of the performance event again" (12). Writing can learn much from performance, as performance challenges writing to re-connect with its own 
performative possibilities. For Phelan, writing about performance is powerful and productive because it has the ability to change the event.

As in modernist literature, performative writing often finds itself unable to realize a satisfying conclusion or completion. Phelan explains that performative writing "enacts the death of the 'we' that we think we are before we begin to write. A statement of allegiance to the radicality of unknowing who we are becoming, this writing pushes against the ideology of knowledge as a progressive movement forever approaching a completed end-point" (17). Performative writing encourages active reading in its development of what John D'Agata calls the "unmapped question"; the quest denies the arrival at a satisfying conclusion, allowing the reader to engage with the writer in imagining possibilities.

Even while describing instances of theatrical or cultural performances, performative writing recognizes the irreproducibility of live performance. In a sense, performative writing attempts the impossible: to pin down and represent an act or action that cannot be reproduced or represented. Performative writing recognizes and is frustrated by its own limitations. Still, because it is rooted in the action of the theater, performative writing attempts to reintroduce flux and uncertainty and even discomfort to language, to resist easy signification and representation. It employs the same tricks, disruptions, and ambiguities that an audience experiences in live theater. This kind of writing emphasizes the physicality, labor, activity, and consequences of words. ${ }^{4}$

A starting point for theorizing this kind of writing practice and its focus on the body can be found within French feminism of the 1970's, ${ }^{5}$ particularly Helene Cixous' "The Laugh of the Medusa." In this notable feminist piece, Cixous asserts that "the history of writing is confounded 
with the history of reason," which is defined by the phallogocentric order (2043). Cixous asserts that women embody new modes of expression that promise to explode logocentric history and knowledge. Women, then, should write their bodies, for "by writing herself, woman will return to the body" (2043). Although French feminists have been accused of universalizing and essentializing female experience, ${ }^{6}$ their work is useful as it presents a mode and motivation for performative writing, an active form of writing that rejects traditional forms of knowledge and breaks down the separation between mind and body.

In questioning traditional forms of knowledge, performative writing as a practice allows the reader to imagine possibilities for alternative and interdisciplinary ways of knowing. In terms of method, Ronald Pelias explains that performative writing abandons rhetorical modes of formal scientific inquiry and relies instead on "mystery" and "lived experience," welcoming "the body into the mind's dwellings" (6-7). Pelias's article is performative in its own tripartite structure: an "apology" in verse form, an argument that defines performative writing linearly, and a personal anecdote. The three styles or modes interact in complex ways as they explain as well as demonstrate performative writing. Pelias notes that performative writing is often written in first person, and it evokes identification and empathetic responses, presenting a "plural I" that represents many perspectives (9). For instance, in her literary and arts column "The Ebony Flute" Bennett strategically switches between first person singular and plural pronouns, depending on the subject she is discussing. She herself seems to make certain assertions as author, while at other times she uses the communal "we" in order to emphasize that she is speaking on behalf of the African American community to combat racism. While performance studies chips away at disciplinary boundaries, performative writing breaks out of traditional modes of knowledge 
transmission and imagines ways in which literature can reach a larger and more diverse audience.

Performative writing is not so much a matter of style and form as a discursive, rhetorical practice. Della Pollock argues that performative writing is both evocative and subjective. It is evocative in that it "uses language like paint to create what is self-evidently a version of what was, what is, and/or what might be" (80). Rather than describing, referencing, or reporting, performative writing uses the "generative and ludic capacities of language and language encounters" to inspire interaction between writer and reader in meaning production (80). One of the main functions of this kind of writing and what makes it particularly evocative for Pollock is the ability of the reader and the writer to perform their own subjectivity:

Writing that embodies this kind of subjectivity tends to subject the reader to the writer's reflexivity, drawing their respective subject-selves reciprocally and simultaneously into critical 'intimacy.' This process is performative precisely to the extent to which it defines the subject-self in/as the effect of a contingent, corporeal, shifting, situated relation — and so itself as shifting, contingent, contextual—rather than, say, as the end-object of a narrowly autobiographical account or the foundational identity to which 'experience narratives' often refer.

This situated and contingent subjectivity appears in Loy's construction of her own character in her autobiographical poem "Anglo-Mongrels and the Rose." It is the dynamic created by this reflexivity and critical intimacy that draws me to the work of the writers featured in my project. They are interested in trying to create an open and reciprocal relation with their specific 
community of readers. In so doing, they adopt a writing practice that engages with social realities and opens possibilities for change.

Finally, because it contains a rhetoric of potential action, performative writing can have real social and political consequences. Pollock argues that performative writing stages a particular type of encounter between textuality and social realities: "To answer to the claims of textuality on performativity is thus not to write less but to write more: to write in excess of norms of scholarly representation, to write beyond textuality into what might be called social mortalities, to make writing/textuality speak to, of and through pleasure, possibility, disappearance, and even pain. In other words, to make writing perform" (79). These "social mortalities" appear in each of the primary texts I explore in this project, and each author engages with them through the reflexive power of discourse and textuality. This attests to the potential social power of performance in writing. Several critics concur with Pollock on this point. Jill Dolan's "utopian performative" imagines performance as social pedagogy and promotes performance as having the ability to enact an ideal future (455-457), while Phelan explains that some feminist critical writing is performative in its function as an "enactment of a belief in a better future; the act of writing brings that future closer" (150). My project will emphasize the ways in which these modernist writers performatively engage with past and present social and political realities while imagining not a utopia, but a more equitable future.

\section{Chapter Overviews}

The first chapter, “Of Marionettes, Boxers, and Suffragettes: Exploring the Mor(t)al Body in Djuna Barnes's Performative Journalism," explores three articles penned by Barnes early in her career, when she was working as a reporter and writer for several New York 
periodicals. I chose these pieces not only because they serve as examples of the kind of sensational journalism and "stunt reporting" that women were participating in at the time, but because they all highlight performance and bodily violence. Whether she is describing uncanny puppet bodies, boxing matches, or force-feeding in prison, Barnes's work serves as a prime example of the kind of writing Phelan describes when she asserts that performative writing has the power to take on the force and affective power of the performance event. One can read Barnes's writing not as a static recounting of an event that has already taken place, but as a dynamic performance of the event itself staged for the benefit of her reading public. As reporter and transcriber, Barnes couples physical violence with a kind of rhetorical violence that plays out on the page, forcing her readers to encounter some of the baser human instincts at play. When Barnes is willingly force-fed in order to write a convincing exposé on the physical and mental abuse of suffragettes in prison, her writing not only calls attention to but intervenes in the violence done to women's bodies.

The second chapter also examines how performance functions in a periodical genre. In “'Literary Chit-chat and Artistic What-not': Gwendolyn Bennett's 'The Ebony Flute' and African American Expressive Culture" I emphasize the ways in which Bennett engages in a kind of performance that is similar to Barnes's in its focus on identity, physicality, and violence, but that takes race and racial relations as its starting point. In Bennett's literary and arts column "The Ebony Flute," which appeared in the Harlem Renaissance journal Opportunity, she develops a performative and intimate voice to draw in her readership. Although Bennett contributes to racial uplift by celebrating the successes of black artists and writers in her column, she also laments the physical and rhetorical violence to which black people were regularly subjected. While Barnes worked to prove her worth as a female reporter, Bennett's task was perhaps even more difficult, 
as Nina Miller attests: "In the configuration of cultural imperatives and possibilities that characterized the renaissance, the bourgeois African American woman found herself with the onerous task of endlessly 'performing' — and proving — her identity to a mainstream public unwilling to believe in her existence" (182). Working to break this socially-enforced invisibility is no easy task. In her column Bennett works against the dominant culture to define black performativity, reject roles defined by white supremacy, and embrace life-affirming forms of expression and creativity.

In chapter three, “'Whadda you think this is—a dress rehearsal?': Performance and Metatheatricality in Edna St. Vincent Millay's Aria da Capo, " I analyze a political protest drama that calls attention to cycles of war and violence throughout history. Millay wrote Aria da Capo to protest the deaths that occurred overseas during World War I. Like Barnes and Bennett, Millay's political and social commentary involves performative representations of violence enacted upon the body; in this case, however, the bodies appear on stage. The play features a fusion of harlequinade and pastoral tragedy. In the harlequinade the clowns Pierrot and Columbine represent implicit violence in male/female relations, while the shepherds in the pastoral act out a microcosm of war. I argue that Millay links these two storylines by enacting the citational aspect of performative writing, which "quotes a world that is always already performative - that is composed in and as repetition and reiteration" (Pollock 92). The version of history that Millay presents in this play is discursive, cyclical, and repetitive; history appears not as text but as living bodies. A narrator controls the action of the play, but at times the characters seem aware of their own theatricality and attempt to circumvent their seemingly inevitable demise. They are unsuccessful, however, and at the dramatic conclusion the two poor shepherds are killed, and their bodies are literally swept under a table; meanwhile, the clowns' repartee 
begins again just as before. Millay's incorporation of metatheatrical moments is notably Brechtian, and these moments of potential human agency draw attention to how performativity functions in a theatrical context and within human relationships.

The final chapter addresses the enforced performance of gender within a restrictive domestic sphere. This chapter builds upon the other three by offering another example of how rhetorical and physical violence are expressed and protested using performative strategies, this time within the genre of the autobiographical epic poem. In "Mina Loy's Identity Performance: Autobiography and the Birth of the Poet in 'Anglo-Mongrels and the Rose"' I highlight Loy's construction of an autobiographical voice that represents a multiple and shifting sense of self, as the Loy-character "Ova" must learn to navigate received social scripts. The poem is a bildungsroman that narrates the developing sensibility of the poet and her ability to perform within and beyond the restraints of Victorian gender ideologies. More specifically, it charts a series of discoveries about the ways that gender and language perform as a pre-linguistic child gains language and learns how to internalize these performances and use them actively as a source of power and creativity rather than passive subjugation. Although the characters in the poem are biographical, Loy draws upon mythic structures and broader social realities, creating an authorial position of presence that is subjective and lyrical. I conclude the chapter with a reading of Loy's Songs to Joannes, which demonstrates perhaps her most famous and scandalous poetic performance of femininity, the height of the expressive power she gains as a result of the early development of her artistic sensibility.

To be clear, my goal is to explore the performative impulses in these writers, not to define or demonstrate the most illustrative examples of performative writing. Nor do I aim to lay out a conclusive and complete definition of performative writing, given the shifting nature of the 
concept and the many forms it can take. Instead, I lead with the writers themselves and map several trajectories of performative writing through these writers and their work. I chose these writers because they employ similar rhetorical strategies and have shared stylistic practices. I set the stage with Barnes to show the relation between physical violence and rhetorical violence; Bennett's performativity involves breaking enforced invisibility and silence and uniting a community; Millay offers a metatheatrical performance that positions human agency against cycles of violence throughout history; and Loy gives a subjective account of the trauma of gender performance. Each chapter explores a different kind of violence and intervenes in that violence, offering commentary and critique in "highbrow" as well as "lowbrow" genres. My project demonstrates the ways in which the practice of performative writing can inform and expand our study of modernisms, genre, and gender. 


\section{Notes}

${ }^{1}$ Although Millay is considered primarily a formalist, certain poems such as "Spring" are written in free verse and engage with techniques and experimentation more characteristic of modernism. ${ }^{2}$ In "Bringing Milkshakes to Bulldogs: The Early Journalism of Djuna Barnes," Nancy Levine argues that Barnes's career in journalism inspired her novel Nightwood.

${ }^{3}$ Fredric Jameson argues that "genres are essentially literary institutions, or social contracts between a writer and a specific public, whose function is so specify the proper use of a particular cultural artifact" (106). In explaining how these agreements function, Jameson uses the example of daily speech acts which are marked by "indications and signals" that are implicitly understood by the listener and allow for an appropriate response.

${ }^{4}$ The imaginative history of words and signification is explored by Peggy Phelan in "The Adventures of Words" in her introduction to Mourning Sex.

${ }^{5}$ Here I am referring generally to the practitioners and theorists of l'ecriture feminine or “women's writing," primarily Cixous, Luce Irigaray and Julia Kristeva, whose ideas are similar but not identical to Cixous'. For instance, while Irigaray focuses on sexual pleasure or jouissance, Kristeva argues that women's writing stems from the pre-oedipal period or the “semiotic.” See Irigaray, This Sex Which is not One and Kristeva, Desire in Language. For a more recent psychoanalytic reading of these theorists see Zajko and Leonard's Laughing with Medusa.

${ }^{6}$ Of course, the idea of essential and universal female sexuality is challenged by many feminist theorists. Materialist feminist critic Monique Wittig argues that "one is not born a woman," that the basis of gender is social and historical, not biological. See Wittig, "One is Not Born a Woman." Judith Butler takes this further when she argues that acts of gender are performances 
with no originals and that sexuality is based on relations of power. See Butler, Bodies that

Matter. 


\section{Chapter 1}

Of Marionettes, Boxers, and Suffragettes: Exploring the Mor(t)al Body in Djuna Barnes's Performative Journalism

The scene: a young woman with fiery red hair dangles 100 feet above the pavement clinging to a rope, skirts billowing, in the midst of a bustling city. The time: 1914. The place: $68^{\text {th }}$ St. in New York City. Passersby stop and point skyward, wondering. People gaze intently from opened windows. Cars slow. The woman's body swings gently in the chilly early November breeze, as if it has no weight to it. Responding to an unintelligible call from a uniformed man on the ground, the woman slowly shimmies down the rope with as much dignity as she can muster, her feet neatly crossed at the ankles. The young woman later describes her experience of "wild sky-tangoing" thus: "I was a 'movie' flashing transient pictures upon a receptive sky" ("My Adventures" 187).

The woman is a young Djuna Barnes, later to become modernist extraordinaire, but trying to eke out a living as a stunt journalist in 1914. This particular stunt takes place at a school for fire-fighter recruits, and it involves acting out three different methods of fire rescue. Barnes's story recounting the event, "My Adventures Being Rescued" appears in the New York World Magazine on November 15, 1914 complete with illustrations of a grim-faced Barnes sporting a canvas belt with a large steel loop and others of her calmly dangling in mid-air. Barnes ramps up the suspense throughout the article, at one point noting, "It is a fearful, almost a terrible thing, to climb onto a level with the sparrow's nests" (185). The article is a sensationalistic piece, full of adventure, intrigue, and emotionalism. Barnes's detailed descriptions are meant to entertain and 
engross her reading public, and in this article she paints a fanciful scene in which she casts herself as the heroine in a melodrama.

Sensational journalism was at its peak in the United States during the early $20^{\text {th }}$ century, and the public enjoyed engaging news stories full of exaggeration and lurid detail. Sensationalism and stunt journalism became the vehicle through which women broke into reporting during this time. Because they were attempting to infiltrate a traditionally maledominated profession, reporting women had much to prove to their editors as well as their reading public, and they often used their bodies to do so. For example, for one of her most famous pieces, an asylum expose, pioneering female journalist Nellie Bly feigned insanity to gain admittance to a women's lunatic asylum in New York. Rebecca Loncraine explains that female reporters such as Bly literally put their bodies on the line in order to hold a job. Loncraine explains, "Stunt journalism reveals the extent to which women journalists who want to work outside the women's pages found that they had to use their bodies, performance and their own experiences as a means of getting a story" (158). Indeed, female news writers in the late nineteenth and early twentieth centuries were often forced to yield to editorial pressure and were confined to specific sections of magazines and newspapers usually devoted to homemaking, fashion, or the arts. Around the turn of the century, however, female news reporters fought for the right to move beyond these "women's pages" and become professional reporters, and by World War II female news correspondents were traveling overseas. Many of these "girl reporters" constructed personas for themselves of audacious and adventuresome modern women in order to appeal to the reading public. These women allowed their public to experience the city vicariously through their own bodies. For a woman working as a reporter in New York City in the early $20^{\text {th }}$ century the streets were simultaneously threatening and thrilling, representing a 
potentially dangerous urban space but also serving as the means to a steady income and, with any luck, a certain measure of fame.

Before launching her international career abroad and attaining her status as a high modernist author of experimental works such as Nightwood and The Antiphon, a young Djuna Barnes pounded the pavement in New York City as a sensational newspaper reporter. Barnes wrote for a number of New York newspapers before and during World War I, including the Brooklyn Daily Eagle, New York Press, New York World Magazine, and the New York Morning Telegraph, among others, as illustrator, reporter, cartoonist, and book reviewer. Barnes claimed to have worked at every English-language newspaper in New York except the New York Times (Herring 76). In Barnes's stories and her pen and ink drawings, the reader catches glimpses of a cacophonous and seething city characterized by its fast pace, diversity, and miscellany. On every street corner an interesting and newsworthy event is occurring, and Barnes is there to report the extraordinary as well as the mundane.

Barnes herself disparaged her early journalism as "rubbish" with little literary merit. Unlike others in her circle, Barnes was not wealthy in her own right. She struggled with finances throughout her life and often relied on the charity of friends, such as Peggy Guggenheim. Barnes stressed that she only wrote journalism in order to put food on the table. However, several critics cite the importance of this work, usually charting themes from her early journalistic pieces and tracing them through her later fiction and drama. In Djuna Barnes's New York, Douglas Messerli distills these continuous themes into a pithy phrase, articulating Barnes's lifelong depiction of the "simultaneity of the beastly and the saintly, of cultures 'high' and 'low"' (12). While critics point out the thematic continuities in Barnes's journalism and her later fiction, ${ }^{1} \mathrm{I}$ am more interested in her journalism as the foundation for her interest in performance and her ability to 
write performatively. In her journalism, Barnes not only creates and perfects the performative persona of a female journalist, but her subject matter and journalistic style exemplify performative writing.

Using three news articles written by Barnes for New York newspapers early in her career, I will analyze the aspects of performative writing that are linked to corporeal performances and bodily violence. The first two feature Barnes as observer or interpreter of a performance. In "When the Puppets Come to Town," published in The Morning Telegraph on July 8, 1917, Barnes visits a traveling puppetry troupe and interviews the puppet master. Published in New York World Magazine on August 23, 1914, "My Sisters and I at a New York Prizefight" finds Barnes observing the bloodthirsty crowd at a popular boxing match. In her sharp and emotive interpretations of performers, audiences, and performance events Barnes tackles complex issues such as mortality and gender, exploring the significance of violence enacted on uncanny puppet bodies as well as the politics of gendered spectatorship. These pieces set the stage for the final article in which Barnes creates a political spectacle with her own body. In "How It Feels to be Forcibly Fed," published in New York World Magazine on September 6, 1914, Barnes pushes the moral limits of representational and performative journalism, as she is force-fed in prison to simulate the experience of British and American suffragettes.

Performative writing can be distinguished firstly by its presentation of textual moments that invoke performance. In much of her "newspaper fiction" Barnes describes performances of various kinds, which is unsurprising given her interest in theater and the theatrical. Barnes is fascinated by the politics of watching, and much of her journalism involves performers and audiences. She attends events such as plays, dances, and fashion shows, but she is also interested in quotidian, seemingly mundane performances that occur in everyday life. In the entertaining 
and alliteratively titled article, "'Twingeless Twitchell' and his Tantalizing Tweezers," Barnes encounters a traveling con-man parading as a dentist who claims to pull teeth painlessly. As “Twingeless Twitchell” takes a volunteer to demonstrate his craft, Barnes turns her attention to the onlookers and muses about the "spirit of the arena," the morbid desire of spectators to see pain or harm inflicted on a human being. Barnes's style in these articles is characterized by authorial subjectivity and perspective, giving her the freedom to turn a critical eye to spectatorial and performative moments and delve into the moral implications of these performances.

Secondly, while performative writing recognizes that it is impossible to directly reproduce a performance event, it attempts to actively take on the force and affective power of the event. According to Peggy Phelan it can be defined as writing towards disappearance rather than preservation (Unmarked 148), echoing the ephemerality of live performance. In Mourning Sex, Peggy Phelan emphasizes that attempting to preserve the performance event through writing should be avoided; rather, we should explore "the possibility that something substantial can be made from the outline left after the body has disappeared" (3). For Phelan, writing about performance is powerful and productive because it has the ability to change the event. Barnes's journalism can be read not as a representation of a past event, but as the very event itself. As Barnes is lowered to the ground in a mock fire rescue or willingly force-fed in prison, her articles present her in situations in which her body is placed under stress or danger for the entertainment of her readers. Loncraine draws a comparison between the immediacy and presence of Barnes's stunt journalism and film, explaining, "A film does not put itself forward as simply a recording of a previous event; it is the event. Barnes's stunt articles function in the same way. Her stunt stories were carried out solely for the purposes of reporting them in the newspapers. They are not simply recordings of an event, they are the event..." (168-169). In this way, one can read 
her writing not as a static recounting of an event that has already taken place, but as a dynamic performance of the event itself staged for the benefit of her reading public.

Finally, performative writing emphasizes writing as a human act as well as an action; it is grounded in the corporality of the body. In a discussion of the interdisciplinary nature of performance studies Dwight Conqergood explains: "Performance studies struggles to open the space between analysis and action, and to pull the pin on the binary opposition between theory and practice" (311). In a similar way, performative writing dwells in this interstitial space between active embodied performances and the supposedly passive act of critical reading. It exposes the ways in which authorship is process and labor, not only calling attention to the physical, mental, and emotional labor of the author herself, but also analyzing others' bodies insofar as their performances warrant social analysis.

As Barnes demonstrates, performative writing has the potential to address the ethical dimensions of embodied violence. Female modernist writers like Barnes use this kind of writing for its rhetorical and subversive possibilities. As reporter and transcriber, Barnes couples physical violence with a kind of rhetorical violence that plays out on the page, forcing her readers to encounter some of the baser human instincts at play. When Barnes is willingly forcefed in order to write a convincing expose on the physical and mental abuse of suffragettes in prison, her writing not only calls attention to but intervenes in the violence done to women's bodies. As a critical practice, then, performative writing has the power to demand social action or change.

In each of the three articles I will explore, Barnes represents a body that is fragmented or under threat of violence, whether that body is headless and fashioned out of wood, cut and 
bruised in a fight, or starving in prison. The purpose of the "Puppets" article is to show the objectification and performance value of a non-human body. The "Prizefight" article ups the ante by showing human bodies in pain, notably lower class boxers, but these bodies are also objectified and dehumanized as if they are little more than puppets. Barnes in her writing is calling attention to the problematic nature of performance and representation, and in "Forcibly Fed" she makes her own body the focus. This article especially raises complex ethical questions about the dangers of representing bodily violence in a political context.

\section{Writing the Barnesian Body}

Walking the streets of New York in a black cape, her red hair swept back in a sleek French twist, Djuna Barnes cut an impressive and mysterious figure, recognized by many but intimately known by few. Brilliant and beautiful with an acerbic wit, Barnes was obsessed with publicity yet guarded her privacy fiercely, once remarking to Harry Remont of the New York Times, "I used to be invited by people who said, 'Get Djuna for dinner, she's amusing.' So I stopped it" (Broe 5). Barnes resided in New York City at the beginning and end of her career, spending the last years of her life as a recluse in a small flat in Greenwich Village. In midlife she resided primarily in Paris where she wrote most of her novels and plays. She was known in Bohemian circles in New York and Paris for her brilliance, her irascibility, her famous bisexuality. ${ }^{2}$ Barnes's reputation preceded her, and she culled her theatrical, performative persona among friends and acquaintances as well as her reading public. Her literature, often labeled as impenetrable, disconcerting, and multi-faceted, contributed to her enigmatic personality. 
Barnes wrote in a variety of genres, but in her own mind her literature was of much higher intellectual value than her popular journalism. As Barnes's biographer Phillip Herring notes, "Success in journalism brought complications for Barnes. That which she valued little sold well; that into which she poured her soul was often seen by editors as a less valuable commodity" (78). Indeed, while Barnes made her living as a journalist her literary ambitions continued to take precedence, yet publishers were seldom interested. Still, although Barnes disparaged her journalism she was apparently affected by James Joyce's opinion that "the extraordinary event was the subject of journalism, while the commonplace was for literature" (Herring 77). Barnes taps into the psyche in her articles, using satire and dark humor to highlight the bizarre and ghastly in modern life. She also provides moments of compassion, giving voice to those who are often silenced in society, the voices of the working class, social activists, women, and minorities.

Messerli's Djuna Barnes' New York, a collection of her articles written for various New York newspapers from 1913-1919, includes unique pieces focusing on performance, particularly rituals enacted on the human body and the presentation of modern female identity. Some critics have described Barnes' style of sensational journalism as the epitome of the highly visual rhetoric which was criticized by press commentators of the time. Providing descriptions of events that occurred around the city, such as prizefights, circuses, and fashion shows, Barnes' writing is highly imagistic, and she often includes her own drawings or photographs to appeal to a mass audience. Barnes wrote objective reportage as well, but, as Nancy J. Levine points out, her more popular work was subjective and observational: "The facts that mattered to her were the marginal, concealed, but vital details that allowed her to respond to the atmosphere of an assignment, to what one might call its psychological environment" (32). This subjective style of 
news writing which focused on description, detail, and observation was in high demand at the time, and Barnes's talent as a writer of fiction contributed to her mastery of the genre.

A recent exhibit at the Brooklyn museum attests to the growing interest in Barnes's early work, emphasizing her journalistic style. Entitled "Newspaper Fiction: The New York Journalism of Djuna Barnes, 1913-1919," the exhibition ran from January 20-August 19, 2012. Organized by Catherine Morris, curator of the Elizabeth A. Sackler Center for Feminist Art, the small exhibition includes Barnes's stories in newsprint, illustrations, and documentary photographs, many of which are on loan from the Barnes archives at the University of Maryland. An article by Jenny Hendrix in The Paris Review introduces the Brooklyn Museum exhibition and explains its focus on "newspaper fiction": "The phrase newspaper fiction was an invention of Barnes's own. She [...] was a believer in what might be called journalism's observer effect, where the presence of someone watching, cataloging, and judging cannot but alter results. And so, finding that she cast a shadow on her observational path, Barnes duly recorded and printed it." This focus on authorial subjectivity and perspective characterizes much of Barnes's journalism.

In terms of her journalistic style, Barnes's work can be seen as a precursor to the "New Journalism" of the 1960's and 70's popularized by Tom Wolfe, which is known for its journalistic use of literary devices and dramatic techniques usually seen in fiction. New Journalism or subjective journalism is also characterized by creative and intensive literary reporting and tends to acknowledge the writer's subjectivity and explore his or her personal perspectives. ${ }^{3}$ Barnes often places herself in the scene as she reports or interviews, sharing personal thoughts and observations. She does not maintain "proper" journalistic distance, nor does she assume the objective, disembodied voice of a traditional news reporter. Hendrix argues 
that as a kind of New Journalism, Barnes's writing would seem foreign to current readers who are accustomed to mainstream news writing: "Barnes's writing would hardly be welcome in the papers today without a sort of disclaimer, bearing more or less the same relation to our journalism as her stylized drawings do to photographs. Her impressionistic observations and anecdotes were often embellished or fabricated outright." Hendrix appropriately uses the language of art to highlight Barnes's “impressionistic observations," using as a point of comparison Barnes's pen and ink sketches and photographs. If we are to assume that photos and objective journalism represent “reality," Barnes's drawings and sensational stories comprise a more interpretive and imaginative genre, a hybrid of fiction and nonfiction.

By breaking out of the traditional objective journalistic style, Barnes achieves a number of desirable effects. First, developing a voice and subjective persona allows her to create a unique space for herself as a female journalist and reporter. She not only reports events but creatively tells of her active involvement in them. She is a storyteller rather than a dispassionate observer, weaving tales of intrigue out of everyday situations. In her early writing Barnes develops a performative appeal to an audience interested in public spectacle. As a combination of fiction and nonfiction her sensational journalism not only questions distinctions between high and middlebrow modernism but also creates a performative voice and persona for the modern female. As a journalist exploring and exposing social and cultural events, at times she simultaneously assumes active and passive roles in a visual economy. In a multilayered representative enactment, she performs as she watches others perform, and recording her experience is yet another performance. Further, this type of experiential journalism lends itself to more passionate activism and attention to social and political issues. Like many other female modernist writers, Barnes's writing is creative and experimental as well as highly political. 
Barnes infuses her reporting with sensation and emotion and focuses on performance, particularly performative rituals and embodied violence.

\section{Marionette Strings and Boxing Gloves: Barnes's Politics of Watching}

In her news articles "When the Puppets Come to Town" and "My Sisters and I at a New York Prizefight" Barnes actively observes and narrates a marionette performance rehearsal and a boxing match. In both instances Barnes witnesses infliction of bodily pain and violence; the difference of course is that the uncanny body of the marionette can only represent or echo human pain, while the fighters embody real pain while serving as spectacle. Barnes narrates both performances and devotes detailed attention to audience response. In the "Puppets" article Barnes interviews puppeteer Tony Sarg, who waxes philosophical about the appeal of marionette bodies, noting that "they are capable of tragedy without annoying anyone by also being capable of tragic emotions." In a pithy distillation of his argument, he assures Barnes that audiences "do not mind the head of the heroine, on or off" ("Puppets"). The puppets cannot offend presumably because they are not mortal or moral creatures. Disturbingly, Barnes's accounts of audience reaction at the boxing match align with Sarg's observations about marionette violence. The crowd at the match dehumanizes and objectifies the bodies of the boxers, rendering them little more than automatons.

\section{"When the Puppets Come to Town"}

They are so impartial. Having no sense of color, a tear means no more to them than a drop of water, a pool of blood nothing more than a pool of rain.

$$
\text { -Djuna Barnes, "When the Puppets Come to Town" }
$$


In "When the Puppets Come to Town" published in July 1917 in The Morning Telegraph, Barnes recounts her visit to MacDougal Street in Greenwich Village where she meets popular German American puppeteer and illustrator Tony Sarg. Sarg later became famous for designing huge helium figures for the first Macy’s Thanksgiving Day Parade in 1928 and for his popular performance at the 1933 Chicago World's Fair. According to John Bell, Sarg's achievement of a "financially viable modern puppet theater parallels the drive and focus of mainstream American theatre that in the first decades of the twentieth century was reaching its peak in New York City" (72). Unlike some of his downtown "little theater" contemporaries who were interested in creating avant-garde theater with puppets, Sarg focused on the more commercially popular genres of comedies and fairy tales. Bell notes that the popularity of puppet performances in New York City at this time owed much to the importance of "art-theater" and functioned as "an articulation of the machine-dominated nature of the twentieth-century" (73). Indeed, the aesthetics of the machine age made their way into the work of many artists at this time.

Barnes's interest in machines, automatons, and uncanny bodies appears in her writing throughout her career, perhaps most notably in her most famous novel, Nightwood. Often her characters seem unnatural and disembodied, as if they are sleepwalking or dazed, moving about their lives compulsively or as purposelessly as robots. Barnes is known for her fascination with surfaces, and indeed some have described her later work as lacking in psychological depth. The "Puppets" article attests to Barnes's early interest in the shallowness and vacancy of puppets and in the separation between body and consciousness. But Barnes is also fascinated by the ways in which puppets, as they channel human emotion, can become uncanny bodies that represent that which is most reprehensible in human nature. As the puppets thrust into each other with swords or knock each other on the head with frying pans, they can have no regard for the consequences 
of their actions, and without a moral base they can experience neither guilt nor regret. Barnes reminds her readers that a similar disregard often appears in human interactions as well. In her journalism, Barnes readily delves into difficult subjects, and "Puppets," while it may seem innocent, is no exception. In this article, as in the subsequent articles I will explore, she exposes examples of an indifference to bodily injury and violence.

In a rather lengthy introduction before her interview with Sarg, Barnes presents a brief history of puppetry beginning in ancient Egypt, Greece, and Italy. Although puppets are often associated with comedy, they also enacted Passion Plays as well as historical dramas such as the battle of Trafalgar. Attesting to its historical and contemporary popularity Barnes observes, "The marionette has something of charm and of value unknown to mere dolldom" ("Puppets"). Indeed, in the article Barnes attempts to uncover the nature of this "charm and value," the fascination with the nonhuman performing body manipulated and controlled from behind the scenes by invisible actors. In her own observations and her conversations with Sarg, Barnes interprets the appeal of performing marionettes, attesting to the simplicity of predetermined action and the threat of violence with no consequences. Marionettes have no moral code, so all they need do is react to the situation before them with no judgment: "Confronted with the sword, they murder. Placed opposite a pair of lips, they kiss. Set among chairs, they set them down, and surrounded by 'cause' they still suffer nothing of effect" ("Puppets"). This inherent simplicity appeals to the audience and allows for entertainment value, apparently without the moral concerns and physical limitations of real human bodies: "They look about them with their wide, calm, carved faces as the female portion of their herd fall like mushrooms beneath the slurring tread of early grazing cattle, and perhaps one more deft in his joints than another will look calmly upon the death pangs of his daughter as he twirls a silky black moustache, caroling in a 
childish voice, "The flowers that bloom in the Spring, tra la"” ("Puppets"). As if this highly imaginative and detailed description isn't enough, Barnes includes a large drawing that illustrates this scene. It features the figure of a woman with a tuft of dark hair and obvious bolts in her shoulders and elbows bending over backward from her impossibly narrow waist. A male figure positioned above her twirls a stringy moustache and looks down upon her with an expressionless face.

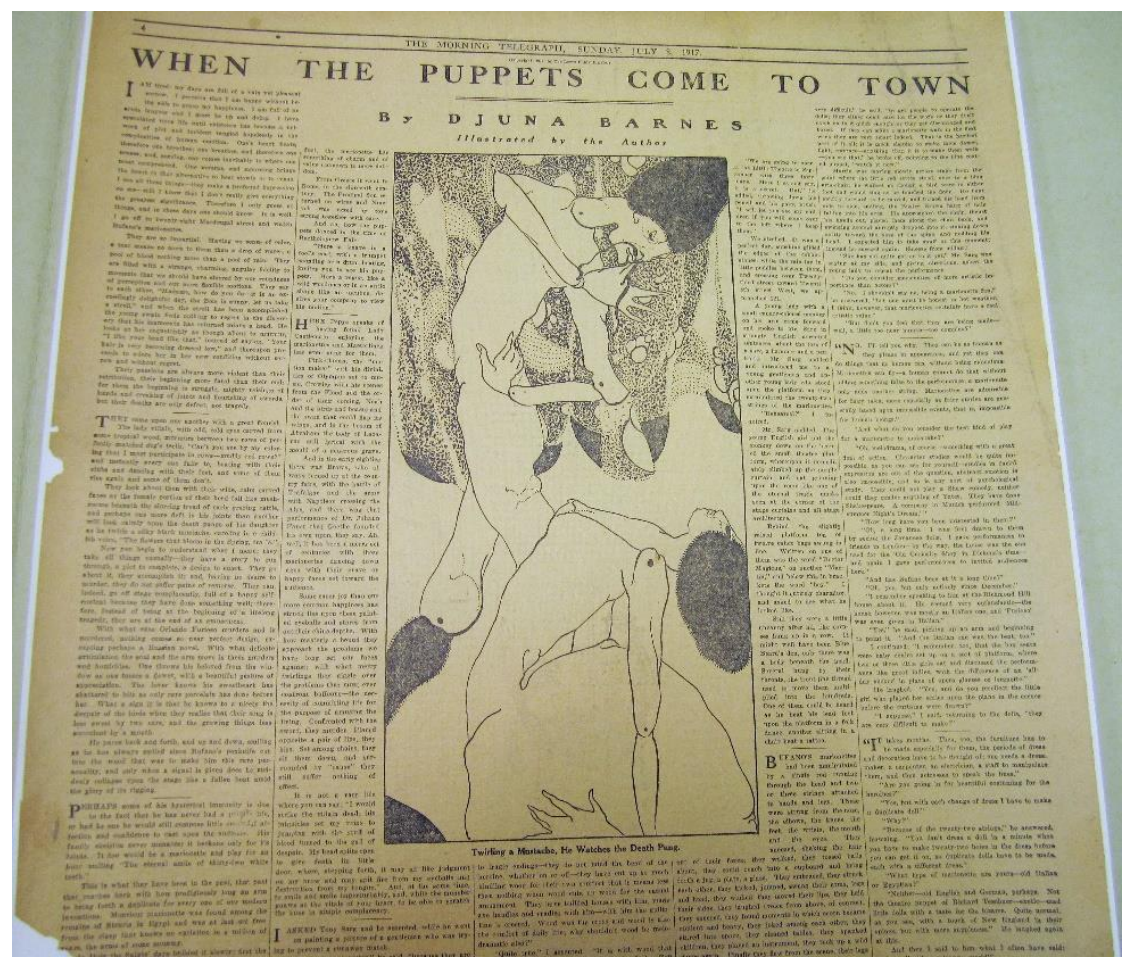

Figure 1.1: Djuna Barnes, "When the Puppets Come to Town," Djuna Barnes papers, Special Collections, University of Maryland Libraries

Barnes at first seems to suggest that violence enacted upon these nonhuman bodies is of no consequence: "Their passions are always more violent than their retribution, their beginning more fatal than their end; for them the beginning is struggle, mighty raisings of bands and creaking of joints and flourishing of swords, but their deaths are only defeat, not tragedy" 
("Puppets"). Marionettes are the stuff of wood and springs, their awkward bodies miming human action as puppeteers attempt to control their unwieldy limbs. When they perform killing or injuring, they are merely defeated, and the show ends. Death and defeat become the stuff of comedic art. Barnes describes the graceful equanimity with which fatal blows occur: "With what delicate articulation the soul and the arm move in these murders and homicides. One throws his beloved from the window as one tosses a flower, with a beautiful gesture of appreciation" ("Puppets"). These nonhuman creations have the ability to transform the terrifically violent into the beautifully tragic.

However, some would argue that puppet performances are far from innocent, and that the audience projects humanity onto the puppet bodies. In his explorations of the aesthetics and phenomenology of the puppet, Steve Tillis attests to the complex signification process associated with puppet performances. The audience engages in what Tillis calls "double-vision," which refers to the seemingly contradictory knowledge that the puppet is an object but simultaneously functions as an imagined life. Tillis explains the role of the audience in actively creating the life of the puppet: "The puppet is but an object constituted of abstracted signs in the perception of the audience; the audience must give meaning to these signs by an act of imagination, according a sense of life to the puppet in response to its abstracted signs" (56). This sign system requires active interpretation, and without the projection of the audience, the puppet cannot signify.

However apparently simplistic the actions of marionettes appear, Barnes understands that through imagination and projection the audience is implicated in the marionette performance. As always, Barnes does not allow the darker overtones escape her notice. The marionettes are uncanny bodies after all, meant to mimic the actions of humans, and they are given their power by the audience. One of the most telling lines in the piece appears when Barnes describes the 
manner in which the marionettes are stored when not in use: "Still they were a little uncanny after all, like corpses hung up in a row. It might well have been Blue Beard's den, only there was a body beneath the head" ("Puppets"). This seemingly offhand description stops the reader short. In her exploration of Barnes's journalism, Katherine Biers discusses Barnes's use of the “dangerously reflexive word-picture," which Barnes employs to "take up the relationship between a violent reduction to the body and an undecidable distinction between words and images" (243). Barnes appeals to a mass audience by painting sharp and emotive word pictures in her journalism. Her own body and the bodies of others are brought into brutal relief in these renderings, as she focuses on bodies in relation and movement, crowds and spectacles, and most importantly, bodies performing various cultural and gendered rituals. Here, Barnes evokes corpses in her "word-picture" as the audience is invited to visualize the horrifically violent image of hanging marionettes as neat row of dead bodies in Blue Beard's den. The audience projects humanity onto these puppets even when they are at rest, rendering them much more than mere machines of wood and wire.

Barnes also expresses a concern in the article that the marionettes resemble human bodies a bit too closely. Near the conclusion of her interview with Sarg Barnes asks the puppeteer, "But don't you feel like they are being made — well, a little too near human — too complex?” ("Puppets"). Sarg replies in the negative, stating that marionettes can perform physical feats that are impossible for humans; thus they work well for genres like fairy tales, where the impossible is standard fare. Sarg seems to have glossed over the deeper significance of Barnes's question, however. Whatever the genre, as marionettes more closely approximate human bodies and human emotion, Barnes wonders if directors and puppeteers have more of a responsibility. After all, one cannot deny the representative possibilities of marionettes, especially as audiences 
endow them with human qualities. As Barnes observes, "it is with wood that we express so much of that which is the flesh" ("Puppets"). If the wooden marionette body is infused with human emotion and morality, the results of those scenes of violence more closely approximate bruised flesh.

"Puppets" provides a useful segue into discussions of Barnes's performative journalism in a number of ways. First, she sets up a representative economy that analyzes the performing body. In the next article I will explore, Barnes makes the crucial step from the nonhuman, uncanny body to the human, mortal body of the boxer. Secondly, Barnes opens up the issue of the effects of violence on the body in a performance context, particularly the audience or viewer response to such acts of violence. In this case, the audience experiences "double-vision," viewing the puppet as passive object and active subject simultaneously. Finally, "Puppets" tackles the difficult issues of moral responsibility in performance and spectatorship. Insofar as the marionette is a projection of the human body, Barnes stresses that we cannot disregard violent actions. It is important to remember that all of these analyses are made possible by Barnes's mastery of this subjective style of journalism, which gives her the freedom to present her personal observations, make use of pathos in appealing to her audience, and explore issues of morality.

\section{"My Sisters and I at a New York Prize Fight"}

Friends had several times asked me, 'Have you noticed that, of late, women have taken to attending boxing matches?' I had not noticed it, but I wished to if it were fact. 
Therefore, one night I found myself at Far Rockaway and in Brown's Athletic Club...The clubhouse stands a few feet from the railroad, inconspicuous, dun colored, crouching.

The women who dared the ringside and the girls further back sit rigidly upright, balanced between wonder and apprehension, their faces set in a fixed smile, as of a man beheaded while a joke still hovered in his throat.

As the worst part of death is not the dead but those that mourn, so it is not the boxer that is horrifying but the crowd that knows no mercy and seeks but sensation. Through the cry that goes up the boxers close on each other, chins thrust out, wary, watching, alert. They come to a lock, where head meets breast. They move stiffly, jerkily. Then the slap of the referee's bare hand resounds on naked flesh; they are thrust apart; then they meet again.

And each one of us, meanwhile, sits motionless, scarce permitting a breath to pass our lips.

-Djuna Barnes, "My Sisters and I at a New York Prizefight"

The previous quote is taken from an article entitled "My Sisters and I at a New York Prizefight” by Djuna Barnes, published in New York World Magazine on August 23, 1914. Prizefighting was extremely popular among the middle class at this time, as fans of the sport waited for a white fighter that could defeat Jack Johnson, the first African-American world heavyweight boxing champion. Although Barnes does not mention Johnson in her article, historically the sport of boxing is heavily fraught with race and class issues. James Rhodes explains that within American and British contexts, the figure of the boxing "hero" has long been defined by his "whiteness" as well as his "working-class" or "blue-collar" identity (350). In 
observing a female middle-class audience's reactions to the male, working-class bodies of the boxers, Barnes exposes a class-based visual economy.

This piece is an excellent example of Barnes's unique subject position, as she directs her gaze not so much to the fighters but to the reactions and body language of the women in the audience. The bodily violence and the exposed flesh of the fighters are not as disturbing as the active restraint of the ladies, the violent undercurrent that runs through the crowd as they observe this spectacle. The prizefight itself is not the primary performance, although it does provide the theatrical backdrop for the scene. Biers describes the theater of action, the boxing ring as "an enclosed, immobilizing space that places the bodies on display. Movement is seen in terms of its immediate constraint" (248). The constrained movement of the fighters in the ring serves as the impetus but not the focus of the scene. The true performance is Barnes's description of the women-their bated breath and their comments on the physicality of the men. In a quiet moment after the match is over, Barnes describes one smiling woman who delicately "picks up the ribs of a broken fan" (172). The fan is an unmistakable reference to the bloody, bruised sinew and the broken bones and teeth of the fighters. The depiction of the woman's delicacy, peaceful demeanor, and sweet smile provide a pointed contrast to the violent bloodbath that has just occurred.

Although Barnes engages in a similar exposé and critique of audience response, the stakes are higher in this article than in "Puppets". The uncanny sight of the hanging puppets reminds Barnes of lifeless bodies, but here living human bodies are bruised and broken, while the blood-thirsty audience cheers and jeers. Similar to the reaction of the audience to the violence of marionette shows, "a pool of blood becomes no more than a pool of rain" ("Puppets") to the crowd at the prizefight. Interestingly, "double-vision" occurs here as well, as the audience 
renders the fighters simultaneously subject and object. They are sexualized yet also dehumanized as their bodies are placed on display for the benefit of the largely middle-class crowd.

The most intriguing part of this article is the blurring of gender identification and the questioning of gender stereotypes. In a reversal of the traditional visual economy, male fighters are the objects of the female gaze, in this case comprised of a lust for violent spectacle. Barnes herself takes on the role of the active male subject viewing the women in attendance from a position of separation as well as identification. Throughout the piece, she narrates the reactions of men and women in the audience, associating male spectators with the business and skill aspects of boxing, while females concern themselves with human and aesthetic elements: "somehow [men] know the things that count in the game, and their interest is proportionate to their knowledge. But the woman's interest lies not in strength but in beauty. She is on the side of the boxer who has a certain trick of the head, a certain curve of the chin, a certain line from throat to brow" (173). Here we see the traditional male/female relation as mind/body split. As spectators the men are associated with knowledge, rationality, and dispassion, while the women appreciate the physicality and emotionality of the fighters.

However, Barnes is not content to leave gender relations at this simplistic level. At the conclusion of the article gender identification becomes blurred as Barnes questions: "Was it, after all, the men in the audience who had been careless and indifferent to pain? Was it the sound of a snapping fan I had heard? Was it a woman's voice who had murmured, 'He has fine eyes?' A woman's hand that had gripped my arm in the dark? A woman's breath that had ceased so suddenly?” (173). Here, Barnes ends the article by questioning stereotypical attributes of male and female spectators of violence. In a witty yet disconcerting rhetorical move, Barnes disassociates voyeurism from gender, focusing on the nature of basic human voyeuristic 
violence. The problem lies in the brutality of this spectatorial scene, a socially-sanctioned performance in which the human body is broken and mangled. In inviting the reader to watch others watching the match, Barnes transforms physical violence into a kind of rhetorical violence.

Many have theorized the ways in which rhetoric and language can signify the body in pain. In his essay, "The Arts of Dying: Celibatory Machines," Michel de Certeau explores the violence of the suffering body and its textual counterpart. De Certeau describes a literary anamorphosis which functions through semantic and lexical strategies such as "oxymorons," “indecent similes," and "catachresis" (159-160). For De Certeau mystic writing involves "wounding" as it "plays on meanings, throwing them off balance" (159). This mode of writing derives from seventeenth century theorists of mysticism and their focus on bodily suffering and torture. In this tradition the wounded body can be "written" by departing from ordinary language and using various rhetorical strategies, linguistic formations, and figures of speech that complicate and obscure meaning.

Barnes's writing attests to this complex and contradictory relation between the body and language. She highlights the parallelism of the injured body and disrupted discourse and meaning, but she also falls into the cleavage that de Certeau describes as "the labor of the negative...the interspace between the body and language" (160). In narrating a violent spectacle, she transcribes her own body as well as the bodies of the other spectators and the fighters. However, her writing does not allow the reader to be comfortable in this relation between physicality and narrativity. At the conclusion of the article Barnes questions the accuracy of her own observations and assumptions related to gender and spectatorship, troubling easy signification and disrupting discourse. In de Certeau's words, she "breaks the closure of the text" 
(157) by disallowing a satisfying and conclusive reading and rendering clear meaning an impossibility. Barnes accomplishes this by disrupting interpretations of normative gendered spectatorship at the conclusion of the article.

As I have noted, the writing in this scene behaves performatively in a number of ways. First, it describes a live performance, relayed as a curiosity or sociological phenomenon. Barnes not only describes the fighters' bodies in relation and movement, but she focuses on the bodies of audience members in response to the scene before them. Secondly, in Barnes's writing on the event, she plays the part of the investigative Nellie Bly style female reporter who infiltrates a traditionally male setting for the sake of a story. In this way, Barnes's writing is an act and an action—she fashions herself as adventurer, stunt devil, prying interviewer, and not-so-casual observer. Finally, the writing of this article "enacts the affective force of the performance event again" (Phelan 12). The immediacy of Barnes's style and her intricate descriptive passages emphasize the primacy of her rendering of the event rather than the event itself. By questioning the classed politics of watching and disrupting discourses of gender, Barnes's specific focus and interpretive depiction of the scene changes the social significance of the event.

\section{Choking and Clutching: Barnes's Performing Body as Text}

\section{"How it Feels to be Forcibly Fed"}

One of the most well-known and controversial articles penned by Barnes describes her experience of being force-fed in a New York prison for the purpose of drawing attention to the plight of imprisoned suffragettes. Although Barnes's writing expressed ambivalence at times toward the suffragettes' cause and their methods, ${ }^{4}$ she explores this issue as a general human rights violation. Some suffragettes who were held in prison in Britain and the United States went 
on hunger strike and eventually had to be released in order to recover their strength. To remedy this situation, thousands of striking suffragettes were forcibly fed by way of a feeding tube which was forced through the nose or mouth and into the esophagus. The practice was traumatic for those subjected to it not only because they were strapped down and force-fed against their will, but also because the procedure itself could be dangerous. The feeding liquid could enter the lungs and cause pneumonia and other respiratory ailments, leading to illness and in some cases death.

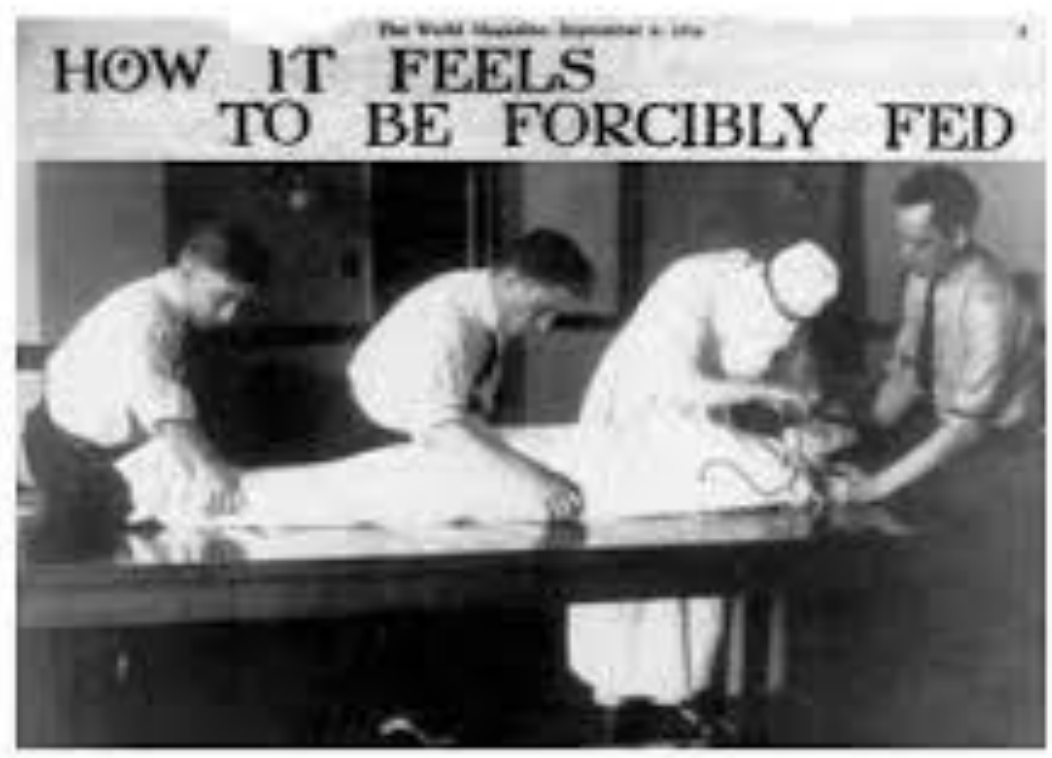

Figure 1.2: Djuna Barnes, "How it Feels to be Forcibly Fed," New York World Magazine, 6 September 1914

Officials attempted to portray force-feeding as a hospital treatment that was used to save errant women's lives, but groups such as the Women's Social and Political Union (WSPU), founded by Emmeline Pankhurst in 1903, worked to expose the danger and cruelty of forcefeeding. In Britain, where the practice was more common, 116 eminent physicians signed a petition against force-feeding suffragettes which was presented to the Prime Minister, but to little 
effect. ${ }^{5}$ In Lisa Tickner's study of imagery of the suffrage campaign she explains the double-bind of force-feeding and its public portrayal: "Clinically, morally, legally, and politically the question was a complex one. The government felt that in effectively allowing women to end their own prison sentences they made a mockery of the law... On the other hand, in preventing suicide either for humanitarian reasons, or an attempt to avoid making martyrs to the cause, they used inhumane means and made martyr-victims nonetheless" (105-107). Indeed, Tickner explains that the activism of the suffragettes relied heavily on publicity and spectacle. The movement was largely based on visual representation, with photographs, drawings, and cartoons affecting public sentiment. The narratives and visuals of force-feeding contributed to the victimization claimed by suffragettes in the media.

An important first-hand account the experience of force-feeding appears in the memoirs of famous suffragette E. Sylvia Pankhurst, daughter of Emmeline Pankhurst, who describes her ordeals in The Suffragette Movement: An Intimate Account of Persons and Ideals published in 1931. In detailed, personal accounts she describes the physical injuries she sustained as a result of force-feeding, including bleeding lips and gums, vomiting, fainting, and intense shoulder and back pain. However, for Pankhurst the psychological aspects of the ordeal were far more violating than the physical:

Infinitely worse than the pain was the sense of degradation; the very fight that one made against the outrage was shattering one's nerves and one's selfcontrol...Sometimes when the struggle was over, or even in the heat of it, in a swift flash I felt as though my entity had been broken up into many selves, of which one, aloof and calm, surveyed all this misery, and one, ruthless and unswerving, forced the weak shrinking body to its ordeal. (444) 
This eloquent account of Pankhurst's splintering sense of self attests to the psychological effects of this method of control. Here Pankhurst represents the "many selves" like shards of shattered glass that rise up and struggle within her. As is often the case during intense physical trauma, her consciousness seems to separate from her body. Accounts like this understandably alarmed the public and inspired sympathy in many for the suffragists cause, or at least admiration for their resolve.

The practice of force-feeding suffragettes was very much in the public eye when Barnes published "How it Feels to Be Forcibly Fed" in the New York World Magazine on September 6, 1914. This article presents a situation in which Barnes is not simply observing a performance. Here, her body becomes a site of performance that, in this case, is representative of oppression. While in "Puppets" and "Prizefight" Barnes observes and theorizes the broken or injured body, here she raises the stakes of her representative economy even higher as she herself is subjected to violent bodily penetration. However, "playacting" at force-feeding certainly raises a host of moral and ethical quandaries. Is the gravity of the issue undermined when it is made into a performance for entertainment ${ }^{6}$ Can Barnes's empathy for the suffragettes be genuine? Does Barnes's body serve as an appropriate mediator between the reader and the suffragists injured bodies, or is her role merely that of an impostor who does not share the passion of the cause?

Although Barnes is "acting," the physical and psychological pain she experiences is real, as her body is subjected to violence and violation. She claims a kind of spiritual camaraderie with the women, if only in her imagination: "The spirit was betrayed by the body's weakness. There it is - the outraged will. If I, playacting, felt my being burning with revolt at this brutal usurpation of my own functions, how they who actually suffered the ordeal in its acutest horror must have flamed at the violation of the sanctuaries of their spirits" (178). This passage bears 
similarities to the excerpt from Pankhurst's memoirs cited above. For both women, the sense of self or the "sanctuary of the spirit" is fractured by the experience. Although Barnes willingly undergoes the ordeal, she believes that her physical experiences allow her to more accurately imagine the real suffering of the suffragettes.

Barnes's description of the scene conjures up two images, one of control and violation, the other of violence and destruction. First, the physical positioning and psychological control of force feeding has been compared to rape. ${ }^{7}$ Here, women are stripped of control over their bodies and forced into a prone position as male doctors or prison personnel assert their power physically. In Barnes's article, the insertion of the feeding tube reads as an unwelcome and violent bodily penetration. The physical control and penetration is a representation of a psychological and social assertion of power. The suffragettes were deprived of agency even to die of starvation in prison as a form of protest. This is an example of patriarchal society taking control and suppressing female agency through women's bodies. Female voices are effectively silenced, literally by a tube lodged in the vulnerable tissue of the throat. One can say that by raising awareness Barnes brings attention to some of these oppressed voices; thus, her performance carried with it a great deal of moral weight.

Secondly, the specter of violent death and destruction infuses Barnes's descriptions of her ordeal:

He [the doctor] took the loose end of the sheet and began to bind me: he wrapped it round and round me, my arms tight to my sides, wrapped it up to my throat so that I could not move. I lay in as long and unbroken lines as any corpse - unbroken definite lines that stretched away beyond my vision, for I saw 
only the skylight. My eyes wandered, outcasts in a world they knew. It was the most concentrated moment of my life. (176)

Death imagery of burial cloths, corpses, and lifelessness appear frequently, as Barnes experiences a gradual loss of control. Mummy-like, she is bound tightly in cloths and lies prone on a table. She struggles to relax her throat, but at one point her will arises, constricting her muscles and causing her to choke. Clearly the mind and body are inextricable here; psychological and social control is represented through physical oppression.

Barbara Green explores Barnes's "performative activism" against the backdrop of the suffrage movement and shrewdly points out the complex layering of representation at work, as Barnes, the "pen performer," engages in her own portrayal of femininity. Green argues that Barnes accomplishes the important task of "rework[ing] the discourse of forcible feeding generated during the British suffrage movement by foregrounding the figure of the woman who speaks from the body in pain, and examining that figure as a problem in systems of representation and in feminist discourse" (Green 70). She reads Barnes's performance as an ironic response which "mimics female exhibitionism and mimes clichés of femininity" (84) and ultimately "creates a space for critique... where the female spectator can recognize the contradictions at work in the representation of femininity" (83). By placing feminine behavior on display in such a way, Barnes mocks stereotypes while critiquing the suffragettes' heavy reliance on spectacle and public display.

However, in "Forcibly Fed" the female body in distress and pain comprise a very real backdrop to Barnes's performance, and this article does not read like an ironic portrayal of feminine behavior, as some of her other articles do. ${ }^{8}$ In a study of Barnes's early journalism, 
Lewis F. Kannenstein stresses the importance she places on the aesthetic, even in matters of mortality: "Suffering becomes tolerable, even purifying, if it is done prettily" (9). This modern attachment to the surface-level and superficial appears in much of Barnes's work, but her attitude can appear flippant when exploring a matter of such political and social importance as suffrage and force-feeding. The gravity of this issue and the license Barnes takes in portraying it differentiates this article from her other pieces. Ultimately "Forcibly Fed" remains a troubling piece and raises crucial questions about the ethics of performance.

In her suggestive and evocative conclusion to this article, however, Barnes acknowledges the moral and mortal imperatives at stake. The ethical quandary is worked out in the writing of these final lines:

It was over. I stood up, swaying in the returning light; I had shared the greatest experience of the bravest of my sex. The torture and outrage of it burned in my mind; a dull, shapeless, wordless anger arose to my lips, but I only smiled. The doctor had removed the towel about his face. The little, red moustache upon his upper lip was drawn out in a line of pleasant understanding. He had forgotten all but the play. The four men, having finished their minor roles in one minor tragedy, were already filing out at the door.

"Isn't there any other way of tying a person up?" I asked. "That thing looks like-“ “

"Yes, I know," he said, gently. (179)

Here, the final vision is comprised of a chilling response to female resistance, the binding and gagging of the female body. The unspoken speaks volumes. Although Barnes burns with righteous anger she only smiles at the doctor, masking the horror she has experienced. At the 
crucial moment she finds herself unable or unwilling to describe or visibly react to her ordeal. Instead, she mirrors the doctor's calm matter-of-factness. Then, Barnes either trails off or is interrupted by the doctor before she can articulate that the binding makes women look like corpses. In the face of such brutality and hostility the enemy is public complacency and resignation, expressed in the gentle tone of the doctor. This Barnes must expose at any cost. Rewriting her final question we may well ask, "Is there way other way of representing this atrocity?" For Barnes the answer is no. There is no easy way to represent such a violation of the human body and spirit. Lest like the doctor we "forget all but the play," Barnes's playacting does the work of calling attention to what is at stake. As I have explained, the audience at a puppet show or the crowd at a prizefight simultaneously renders the actors subject and object in a move Tillis refers to as "double-vision." Disenfranchised and violated, the women in their prison cells are rendered little more than marionettes hung up in a row. In "Forcibly Fed" Barnes not only demonstrates but performs the grave dangers of this objectification and its political and personal consequences.

\section{Barnes's Uneasy Place within Modernism}

Although Barnes may be better known for her high modernist experimental work, as a combination of fiction and nonfiction her sensational journalism is crucial to her development as a writer. Not only do her articles question the distinctions between high modernism and popular journalism, and in them we can identify the beginnings of a common performative thread that appears in Barnes's work throughout her lifetime. In her early popular writing Barnes develops a performative appeal to a mass audience interested in public spectacle, and we can read these experimentations as precursors to the themes and performative styles featured in her later fiction and drama. As she develops her performative writing in these early articles, Barnes begins to 
explore themes that will appear throughout her career: the machine or uncanny body, gendered spectatorship, bodily violence, political spectacle, and the morality of representation.

Given Barnes's unconventional corpus, many critics find her work difficult to interpret and categorize. Tyrus Miller explains that given its form and content Barnes's work does not fit comfortably within the tenets of modernism: "Essential to Barnes's whole literary corpus is a certain 'positionless' quality, its generic and categorical uncertainty and its correlative unsettling of literary historical oppositions like modernism and postmodernism" (124). For Miller, Barnes and some of her contemporaries such as Wyndham Lewis and Samuel Beckett fall under the rubric of what he calls "late modernism" which has more in common with postmodernism. Barnes's themes extend well beyond modernist alienation into something much deeper, as she moves toward a deconstructive impulse, emphasizing failure and the futility of redemptive strategies (Miller 151). For Barnes there is no overarching symbolic unity, only negativity and an absence of definite meaning.

Barnes also engages in genre play throughout her career. Beginning with her journalism and extending to her novels and plays, Barnes breaks out of traditional generic categories and introduces foreign elements into her work, effectively destabilizing meaning. Daniela Caselli notes that this profusion of genres is part of Barnes's "improper modernism," explaining that “the paradoxical promiscuity of Barnes's corpus-which embraces many different genres, creates unmodern precursors, and consistently equivocates - makes up its own impenetrable and thus potentially threatening quality" (4). This threat comes from the purposeful ambiguity of Barnes's work, making it difficult to categorize according to literary period or genre. 
Especially in her novels Nightwood and Ryder and in verse plays such as The Antiphon, Barnes's deconstructive strategies extend into her form. Her organizational schemas often rely on the use of interconnecting scenic fragments and recurring signs and symbols, rather than linear plot structure and traditional character development. According to Carolyn Allen, Barnes “made her own mark on modernism not with Joycean mimetic 'streams of consciousness' to convey unconscious feeling, but with a kind of narrative indirection characteristic of poetry. She often presents scenes and characters so that the reader seems to be at one remove, as if watching the action through a camera in the process of capturing the scene" (150). This "narrative indirection" often occurs in Barnes's journalism, as she observes and analyzes the scenes before her for her reading public.

I have outlined above the common arguments for the impenetrability of Barnes's work and the difficulty in classifying her diverse corpus. Barnes's early journalism, which is often brushed aside as unsophisticated and unimportant, can provide a useful lens through which to view her later work, in terms of both form and theme. Barnes establishes a sense of distance through the use of visual tableau in her literature, creating a text of surfaces and scenes for the audience to observe. Undoubtedly her early journalistic style provided the foundation for this descriptive and performative mode of writing. In exploring the underbelly of society-puppet performers, boxers, and suffragettes-she engages with the gender and class issues as well as the political causes that will inspire her later focus on the disenfranchised and the outcast. By isolating the body under threat of violence in Barnes's journalism, we can begin to follow the "writing" of that body throughout her career.

*This is a working paper for "Of Marionettes, Boxers, and Suffragettes: Djuna Barnes's Performative Journalism." Journal of Modern Literature 39.1 (Fall 2015), Indiana University Press. 


\section{Notes}

${ }^{1}$ For example, in "Bringing Milkshakes to Bulldogs" Nancy Levine argues that Barnes's career as a journalist was the seedbed of her greatest novel, Nightwood and for this reason her articles are worthy of study, "setting aside questions of merit" (27).

${ }^{2}$ Most critics refer to Barnes as bisexual, however herself claimed she was heterosexual and “only loved Thelma," meaning Thelma Woods, with whom she had a tumultuous long-term lesbian relationship.

${ }^{3}$ See Tom Wolfe's The New Journalism.

${ }^{4}$ For example, in her article "Seventy Trained Suffragists Turned Loose on the City" Barnes mocks Carrie Chapman Catt and her suffrage school, deriding Catt for her detailed instructions as to the dress of future oraters, etc.

${ }^{5}$ Medical opinions on forcible feeding can be found in Pankhurst's The Suffragette Movement $\mathrm{p}$. 317-319.

${ }^{6}$ Rebecca Loncraine explains why this particular article is socially and morally problematic: "Barnes takes a scenario from a contemporary political campaign and places it in the context of popular vaudeville entertainment" (159).

${ }^{7}$ Tickner asserts, "It is not hard to understand how the instrumental invasion of their bodies by force, in a process accompanied by great pain and personal indignity, was felt as a kind of rape by the women who suffered it (though the word is not used directly), and that the sexual analogies present in their descriptions cannot be dismissed as the turn of a phrase, but were present to both parties in the experience" (107).

${ }^{8}$ For example, in "My Adventures Being Rescued," Barnes is rescued by a fireman in a mock fire escape, and she pokes fun at the convention of the "damsel in distress." 


\title{
Chapter 2
}

"Literary Chit-chat and Artistic What-not":

Gwendolyn Bennett's “The Ebony Flute” and African American Expressive Culture

\author{
I want to sing Harlem on an ebony flute \\ While trap-drums ruffle to a crash and blare, \\ With a clear note
}

From a sylvan throat

Of a clarinet-of a clarinet!

God and brute, black god and brute

Grinning, brooding in the murk air, Moons of flame and suns of jet, Hurricane joy and dumb despair.

-William Rose Benet, "Harlem"

For poet William Rose Benet the best way to express the euphoria and anguish of 1920s Harlem is by poetically conjuring melody and harmony, cacophony and dissonance. The poem above is characterized by contradictions: the "black god" and the "brute," the exalted and the damned both "grin" and "brood." This simultaneous and paradoxical "hurricane joy and dumb despair" is the climax of the poem and the theme of the song of Harlem. Poet, artist, and columnist Gwendolyn Bennett was quite taken with this poem; it inspired the title of her monthly literary and arts column which appeared from August 1926-May 1928 in the National Urban League's Opportunity: A Journal of Negro Life. In the first installment, Bennett begins by explaining the naming of her column "The Ebony Flute." The above poem, "Harlem," by William Rose Benet had recently appeared in the Theater Arts Magazine, and the first line reads, "I want to sing Harlem on an ebony flute." "So lovely a name it is," Bennett muses in her August 
1926 column, "that I should like to have made it myself, but I didn't" (260). Bennett claims that she "stumbled upon" the poem, but then cautions that she uses the word "stumbled" advisedly. A hallmark of Bennett's whimsical and lyrical prose style in the column, her first paragraph charms the reader with its light-hearted tone and playful enthusiasm. As Bennett indicates here in her introduction and throughout her column, her writing practice is purposefully and carefully constructed to appeal to her readership. "What a lovely thing it is!" Bennett says of Benet's poem, noting that "an ebony flute ought to be very effective for most any kind of singing... a flute that has double quality of tone, low and sweet or high and shrill, that would make of Harlem or any other place a very human song" (260). The "human song" of 1920's Harlem consists of hope and accomplishment, but also conveys the heavy burden of representation for African Americans.

"The Ebony Flute" details important publications, events, and people both within and beyond the African American community in 1920's Harlem. The column features reviews of poems, novels, and plays, relays gossip about major figures of the Harlem Renaissance, and publicizes literary contests for African American writers. In engaging with social, political, aesthetic, and racial issues in a periodical format, Bennett's column addresses the concerns of a specific community and serves as a public forum for discussion. By highlighting African American intellectuals, writers, and entertainers such as Langston Hughes, Countee Cullen, W.E.B. DuBois, Josephine Baker, Paul Robeson, and Nella Larsen, Bennett not only exposes the networks of affiliation and mentoring that occurred within Harlem's literary and arts scene, but she positiona herself as someone "in the know," reporting inside information, promoting literature and culture, and advertising black advancement in the arts. 
When this column first appeared in Opportunity Bennett was 24 years old, but she was no stranger to the publishing world and already a major figure in the New Negro Movement. A month prior to the publication of the first installment of "The Ebony Flute," Bennett returned to New York from Paris; she had received a scholarship to study art abroad while on sabbatical from her teaching job at Howard University. Bennett had studied art briefly at Columbia University and she graduated from Pratt Institute in 1924. By this time, Bennett had already published drawings and poems in The Crisis, the journal of the NAACP, and Opportunity. Throughout her life, Bennett showed promise in both writing and visual art, but she never seemed to be able to choose between the two, dividing her time between both pursuits. Unfortunately, Bennett never produced a collection of her own poetry, although her pieces appeared in various anthologies throughout her lifetime. All but one of her paintings have been lost, ${ }^{1}$ but several of her pen and ink drawings that were published in Opportunity and The Crisis survive.

Bennett's column "The Ebony Flute" is a testament to race-building in the performative centers of Harlem — the stage, the cabaret, the jazz lounge, and the concert hall. Koritha Mitchell explains, "African American expressive culture that asserts racial pride and records achievement is not best understood as a response to white oppression but rather as a sign that blacks valued the continuation of their traditions" (7). This is very much the spirit in which "The Ebony Flute" is written. Bennett's column is not only an archive of black art and achievement, but also an intimate performance space in which she addresses the Harlem community using colloquialisms and gossip. Bennett celebrates what Mitchell terms "embodied practices of black belonging," which include "theatrical performance" as well as "everyday activities and simple gestures" (14). Mitchell draws upon Performance Studies for her definition of "embodied practice" as "a bodily 
act that conveys meaning" and attests to the "centrality of performance in how human beings make culture and live their lives" (5). "The Ebony Flute" acts as a forum for discussion of theatrical performances in Harlem, including plays, musical revues, and concerts, as well as everyday cultural performances of racial belonging which appear in language, dialect, and writing style.

The development of black expressive culture functions as a dynamic response to historical and systemic racism. In a discussion of the maintenance of the color line in $19^{\text {th }}$ century America, John Ernest describes the "experience and performance of social identity" in a society in which laws pertaining to race were unsettled, rendering racial identity contingent and unstable: "While race is a systemic, historical construction, it is also the developing and dynamic response to that construction - the traditions, rhetorical maneuvers, and ideological methodologies of survival, resistance, and collective self-definition that operate in the racial state" (472). These traditions, maneuvers, and methodologies that were developed in response to the instability of racial identity include performances of belonging and community-building. In her column, Bennett strengthens the "collective self-definition" of the race by appealing to a stable sense of identity and cultural identification even in the face of historical prejudice and violence.

Public, communal performances functioned as a celebration of the survival and perseverance of the black race. David Krasner attests to the importance of performance to African Americans, who had historically been denied their right to full personhood: "Black performance was a healing process against dispersion and diaspora; by singing spirituals in church or performing the blues in nightclubs, performances and audiences created a perspective on the world, one holding together what the modern age had fragmented and shattered. 
Performance gave life meaning; it promoted a social cohesion through communal ties and ritual practices" (12). By highlighting black theater, dance, and song in the public arena Bennett fights against diasporic tendencies of modernity for African Americans, strengthening the sense of belonging within the black community in Harlem and extending outward to other cities in the United States and abroad.

In his exploration of African American transnational print culture between the world wars, Brent Hayes Edwards cautions against reducing the term "diaspora" to abstraction, meaning the scattering of Africans, their underlying, essential sameness, and a return to origins. ${ }^{2}$ Instead, Edwards proposes an anti-abstractionist interpretation that "forces us to articulate discourses of cultural and political linkage only through and across difference in full view of the risks of that endeavor" (13). In considering the effects of African diaspora we must take into account "a "history of forced migrations and racialization" (13). ${ }^{3}$ Thus, a discourse of diaspora must recognize difference and acknowledge the effects of a history of violence and separation which may render translation and articulation difficult. In "The Ebony Flute” Bennett often gestures toward a national and international black community of which Harlem is only one part. She attempts to draw out these linkages even while writing intimately to a specific community. By performing her voice as she does in the column, Bennett acknowledges that black communities in Harlem and elsewhere are not monolithic entities but groups of people with diverse histories that often involve racism and violence.

Bennett's project in "The Ebony Flute" is to combat the desecration and literal splintering of the black body, family, and community. Bennett and other black performers, artists, and writers fought against the dispersion of black community and family ties brought about by lynching and other acts of violence. In "The Ebony Flute" Bennett makes use of performance to 
strengthen community in a number of ways. First, by developing a performative and intimate voice to draw in her readership, Bennett creates a safe performance space in which to unite the black community in Harlem and beyond. In her discussions of theatrical as well as cultural “every-day” performances, Bennett identifies and subverts harmful stereotypes and demonstrates ways in which black Americans can mobilize performance to reaffirm their own personhood. Finally, by referencing specific instances of racism and racial violence that fragment the black body and threaten community, Bennett draws attention to white "theaters of mastery" and suggests that black performativity involves rejecting roles defined by white supremacy and embracing life-affirming forms of expression and creativity.

There is still a lamentable lack of critical work on Bennett, although her writing was included in numerous important anthologies in her own time, such as Countee Cullen's Caroling Dusk, Alain Locke's The New Negro, and William Braithwaite's Yearbook of American Poetry. Sandra Y. Govan began recovery work on Bennett in the 1970s and 80s and published several articles in subsequent decades on her life and work. ${ }^{5}$ According to Govan, "In her day...Bennett's poetry was well received, even heralded. She was considered a skillful and evocative lyric poet who also made use of such recurring New Negro themes as pride in and celebration of black racial heritage, the importance of cultural icons, recognizing black folk experience, and commemorating the exuberance and camaraderie of youth on the move" ("A Blend of Voices" 92). In the late 1980s and 1990s Bennett was acknowledged as a major figure of the Harlem Renaissance, as more extensive explorations of her work appeared in Color, Sex, and Poetry by Gloria Hull (1987) and From Harlem to Paris: Black American Writers in France by Michel Fabre. Since 2000, Michael Chaney published an article on Bennett's popular short story "Wedding Day"6 and Claire Oberon Garcia explores Bennett and other black female 
afromodernists in Paris in another recent article. ${ }^{7}$ Bennett's column, "The Ebony Flute," is mentioned in a few studies of $20^{\text {th }}$ century African American periodicals, ${ }^{8}$ usually in conjunction with other literary columns by Harlem Renaissance writers, such as Countee Cullen's “The Dark Tower."

In the recent May 2013 issue of $P M L A$ excerpts of "The Ebony Flute" appear in the "little-known documents" section, edited and introduced by Belinda Wheeler, who is also currently writing a critical assessment of Bennett's artistic work. ${ }^{9}$ Interest in Bennett and her writing and art is increasing, and rightly so. Still, an extensive study of "The Ebony Flute" has yet to appear in the critical literature. In her introduction, Wheeler stresses that Bennett's purpose in the column was to unite "diverse groups," namely those living outside of Harlem as well as older African Americans and members of the New Negro movement, who were often divided by artistic and cultural differences (745). This artifact of the Harlem Renaissance is worthy of more critical attention not only because of its authorship and diverse readership, but because of its style, which is more colloquial and meandering and less formal than other columns such as Cullen's, for instance. Further, Bennett's focus on African American performance in the column not only gives the reader a unique view of the Harlem Renaissance as seen from the interior, but she demonstrates the importance of performance in building identity and a sense of community within Harlem and beyond.

\section{The "Chit-chat" and the "What-not": "The Ebony Flute" and Performative Language}

Periodical culture dominated the 1920s and came to be a significant part of the "New Negro Renaissance," as it was called at the time. Opportunity: A Journal of Negro Life, published by the National Urban League and edited by Dr. Charles S. Johnson, pledged to 
"devote itself religiously to an interpretation of the social problems of the Negro population." The publication's manifesto stresses that the "policy of Opportunity will be definitely constructive." The journal's motto, "Opportunity not Alms" points to this constructive and creative approach. Johnson, a renowned academic and later president of Fisk University, believed strongly that the exemplary art and literature emerging from the black community would at some point receive its due recognition by white critics and publishers. According to Sondra Kathryn Wilson, "Charles S. Johnson accomplished a twofold objective [in Opportunity]: he had ingeniously launched an American literary reform that helped to transform race relations, and he had catapulted into publication a comprehensive body of black literature" (xxi). This “comprehensive body of black literature" was partly derived from Opportunity's literary contest winners, including Countee Cullen, Langston Hughes, and Zora Neale Hurston. The generic proliferation of stories, illustrations, reviews, social treatises, and bits of gossip reflect the broad scope of social and cultural life in Harlem during the 1920s.

The growing popularity of Opportunity was partly due to its inclusive approach. During the early 1920s, Opportunity was not as widely read or circulated as another publication with which it shared a friendly rivalry, W. E. B. DuBois's The Crisis, an organ of the NAACP. The Crisis published social and political treatises as well as literary pieces by influential AfricanAmerican authors. However, although The Crisis had reached 100,000 copies in circulation by 1920, it had dropped to approximately 65,000 by 1926 , the year Bennett began writing her column in Opportunity. By 1928, the final year that “The Ebony Flute” appeared, Opportunity's circulation had risen to approximately 11,000 . The cost of the journal was 15 cents, and it enjoyed a broad readership that extended beyond Harlem. As Nina Miller points out, "the renaissance took Harlem as its symbolic, affective locus, but the majority of people for whom the 
movement was a matter of active and intense interest lived elsewhere" (227). Given this fact, "the renaissance had to be visibly and explicitly constructed" by literary journals and writers like Bennett, whose "occasionally whimsical, deliberately inclusive voice...brought the renaissance into being for her readers" (227). "The Ebony Flute" and publications like it did the important work of creating a sense of solidarity among geographically diverse readers.

"The Ebony Flute" is notable for the ways that Bennett not only references performative moments and contexts in everyday life, but also performs in her writing. Her writing style replicates patterns of speech and colloquial expression, transforming the writing into a dynamic personal chat with her readers. Through her use of language she reaches out to her readership, drawing them into her intimate circle of news and gossip. In this way, Bennett creates a dramatic and performative literary persona for herself, carefully constructing a voice that is meant to build community. Bennett's column "The Ebony Flute" incorporates a wide range of literary and artistic happenings centered in Harlem. Bennett includes announcements about published works such as poetry, anthologies, and novels, as well as performance events such as plays and concerts. Her coverage of these events does not usually extend to full reviews, but she includes brief statements on the merit of the work or performance and occasionally quotes from other writers. She includes travelogues and bits of gossip on the "who's who" of the Harlem arts scene. Clearly the main purpose of the column is racial uplift, and to that end Bennett includes any and all educational or artistic endeavors and successes that encourage racial understanding. In order to expand their ranks, Bennett usually concludes her columns with information about upcoming literary contests for young African American writers, and she consistently encourages new participants. 


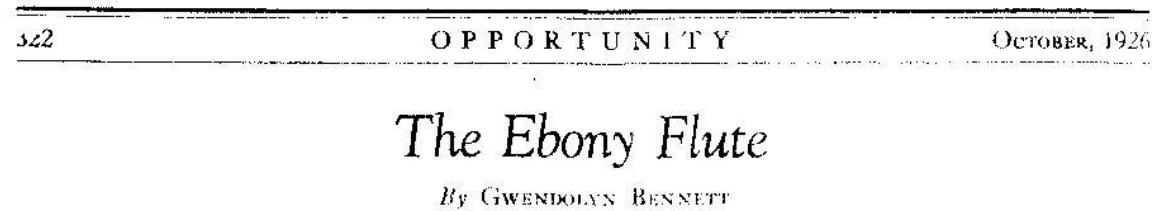

COMES first a very charring letter from Wash. $C_{\text {ington and from Georgia Douglas Jolnston her }}$ very self, saying: "I like the Ebony Flute. . I I very self, saying: "I like the Ebony Flute. -
like those lines of Alexander's very much myself. He The those lines of Alexander's very much myself.
is now in Philadelphia working at the Exposition. is now ith Philadelphia working at the Exposition.
He will be so happy to know that his poen has beer. He will be so happy to know that his poens has been
cited . . then, too, a lriter from William Stan ley Braithwaite wherein he pays us tle delighteful compliment of saying: "You have made The Ehgag Gilute attractive and interesting and I am lonking torwas do each moath as a sart of persoasl clat with you about books and things." - Eugene Gordon of Boston makrs the pleasing gesture of an enthusiasin which calls forth two letters. . he throws us this dieliciouss swectmeat: "Helene Jobnson is a member of the $S_{a t u r d a y}$ Evening Ouill Club (of which I happen to be president), as is also Dorothy West, whose story was printed in thie July OpPorTunity. These girls ate of their work both so modest that they do not spenk

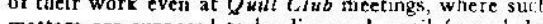
matters are supposed to be discussed, uncil formal themand the ben made upon them. I was both surprised and delighted to note according to The Ebony Flute
that Heiene Johnson is to have three poerns in Braith-
waite's Anthology."

wait's Anthology."
This Quill Clab interests me . . here we have such people as Helene Johnson of such rare talent chatting with Eugene Gordon whose articles on the Negro Press have appeared in many toayazines in. cluding the American Mercury. He, by the way, is writing a series of articles for the Fourth Fistate published at 25 West 43rd Street, New York City he will discuss the Negro Press and Publications. The first two appeared in the issucs for July 24th and 31 st. Dorothy West, whose Typewriter was awarded the serond prize in the Shy Trorter was awarded the second prize sin whe Short Story Section of the member member ${ }^{*} \cdot{ }^{\circ}$ she las been contributing short storites to the Bostn Post and has developed quire I following. - We who clink our cups over New York fire-places are wont to miss the fact that iittle knots of literary devotees are in like tmanner sipping their "cup," 0 ' warmth" in this or that city of the "provinces." Which reminds me that I have heard Georgia Douglas Johnson say that there is a Saturday Nighters Club in Washington, too.

Well now that the Bani Contest is closed what we? Certainly the breathless waiting until the ids are announced will keep us keyed up to the proper pitch that should greet the coming of this prize-winning novel hy a Negro. Speaking of novels, I bethink me of all the people I have heard say they were going to write novels in the conning year. cugene Gordon sets the pace at two which he plans compieting by May lst. - Frank Horne, hailnotes that deal with his cerebral younglias piles of Which teminds us to what extent the vogue for Nigger Hoeven has set its tentacies upon Negero rezders. I have seen the pale blue jactet with its discreet white printing in more brown axus than I have ever scen any one other book. Is it that we like so much reading about ourselves or are we par-
ticularly interested in Mr. Van Vechten's reaction to as whom the has knowa so well? With the critus " the New York journals giving it a friendly pat

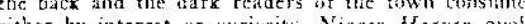
rither by interest ar curiosity, Nigger Heaven ough man.

Other contests descend hipon us

there is th new edition of the Opportunity Contest for this term ing year with Mr. Holstein hoiding out a gracios band wa the new Negro . . the Crisis awards t be frade in a comparatively short time . . . a $\$$ in: reward for the most convincing proof as to who : the anthor of The Yarn of a Yankee Prirateer--the date is January lst; the address is Funk and Waghalis Company, 3.94-360 lonrth Averue. New York

there will be Sesqui. (entennial Awards to be give:

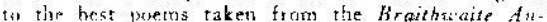
thalogy . prizes of $\$ 100, \$ 50$ and $\$ 25$ will be

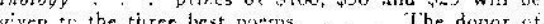

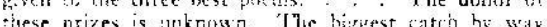

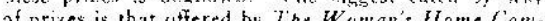

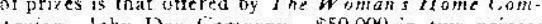
panson-

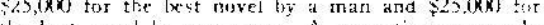
the best novel by a womun. A comprtitor may suh. ment more than mise masuscipt and any author is
eligible "regardiess of nationality." The Jate for the matluscript to be in the hands of the judges is Jitly 1. 1927. The address is The John Day Company. 25 West 45 th Street, Now York City. it seeris that with all this callseway one of two of our youther writers ought to be able to procure the mitans sf : mere sustenance at any rate.

The question as to the finest, mast beautisni or best line of poetry wxitten by a Negro is still of mosiest. Miss Mary $P$. Burtill, teather of Dramatics at Dunbar Hight School, says: "I was interested in the discussion of the finest lines by a Veuro met. I I m me these lines by Claude Mcka? fiave a beauty that no Vegro poct has equaled: in Wave a beauty tiat no tegro poct has equaled; in
fact few poets of any race or clime have surpassed fart few
them"-

Her voice was like the sound af blended Autes Blown by biark plagers on a picnic day.

Frank forne flashes his lance in the firay witl these words: "Interested in your quest for the best lines of poetry by a Negro. It is no doubt true that most of the lines of sheer beauty must be sought atrong tie of the lines of sheer beauty must be sought atriong the
'very' moderns. B But this line from Paul Lawrese "very' moderns. But this line from Paul
Dunbar's poem is always be auty for me--

Fre sleep comes down to sathe the weary eyes-

a line pregnant with soift sounds and vast mystery o? infinite space. . And this trotn Claude McKay's Harlem Shadowg-

Through the long night until the silver break

Of day the little gray feet knowi no rest.

utterly gorgeous expression of the poignant gray restiessness of a race, from dawn through eternal night. the last line from his little poem, If I Were Paris, in whick lise extols "the woman sweetly ripe"-
GCTOBER, 1926

And utterle

And this ecstatit Eaction in Cane

fier skin is

dikh fram Jessi genus bit:- -

$l^{m a}$

Stabs

which o

-inese lines:

That ora

to $\operatorname{crar}$

Fion Langston

Beat the dr

And let th

besides knou iir. Horne als fellow poets

it is but a tho.

This

C) Ciscinnati $A$

$Y=$

Sion

onls

$K n$

Suci

You

liki

You

Cioi

Oni

Kni
Abi

Snis

f. P. MEEvo in Americana is revue,

Hallelujah. whose color

intricacies o: come the ret gotten race. in Block $B o$ minded of a iurae for $\mathrm{Se}$ blunders thr seems has w:

being taken Roof comes : rence must : inclusion:

Figure 2.1: Gwendolyn Bennett, "The Ebony Flute," Opportunity, October 1926 
An illustrative column published in October 1926 demonstrates Bennett's common structure and content in "The Ebony Flute." She begins by quoting from various correspondences, notably "a very charming letter" from Georgia Douglas Johnson in which she praises "The Ebony Flute," and another from Eugene Gordon that informs Bennett of the activities of the Saturday Evening Quill Club in Boston, of which Helene Johnson and Dorothy West were notable members. She details recent publications of Johnson and West, reminding readers that "we who clink our cups over New York fire-places are wont to miss the fact that little knots of literary devotees are in like manner sipping their 'cup 'o warmth' in this or that city of the "provinces"' (322). Throughout the column, Bennett makes a point of reminding her readers in Harlem that they are part of a larger African American literary and arts community that extends to other cities in the United States and Europe.

Bennett then revisits an ongoing aesthetic quest she initiated in "The Ebony Flute" to find "the finest, most beautiful, or best line of poetry written by a Negro" (322). In the first column in August 1926, Bennett and poet Clarissa Scott had pondered this question, and Bennett periodically returns to it. In the October column, Bennett includes opinions of readers who wrote in to weigh in on the "contest" of sorts, and Bennett quotes poetic lines suggested by her readership that are penned by Claude McKay, Paul Lawrence Dunbar, James Weldon Johnson, Jean Toomer, Jessie Fauset, Countee Cullen, and Langston Hughes. When no conclusion can be drawn as to the best line of poetry Bennett observes, "But all that resolves itself into the hopelessness of deciding what the greatest of anything is...nothing is really greatest but greatness itself..." (August 1926, 261). Of course, determining the "best" line is unimportant and impossible; the value of the list lies in demonstrating the quantity and quality of talent among African American poets. The way in which Bennett presents the work of these poets on the page 
attests to the power of community rather than individual talent. By drawing lines out of various poems and italicizing them to draw the reader's eye and distinguish them from the rest of the prose, Bennett in essence constructs a new poem out of pieces, a poem that is much richer and more varied than each poet could have developed on his or her own. Bennett beautifully represents the creative, collective voice and intimate community of African American writers by showing that a whole can be constructed out of fragments.

The "singing" of Harlem through the metaphorical ebony flute is not a singular enterprise but a communal effort. Bennett frequently includes quotations from poems, reviews, personal letters, and news articles, bringing a variety of genres and voices into the column. For instance, in the October 1926 column after Bennett quotes from the work of various black poets, she includes the full text of a poem entitled "Dark Dancer." The first stanza reads thus: "You are a black rose / Slowly bending / Against the crying red of sunset" (323). The poem is notable for its focus on physical movement and performance in the form of the dancing body. Despite the limited space of the column, Bennett often uses extended quotations from others in order to encourage important conversations about race and performance. While Bennett's authorial voice functions as the melody, the organizing principle, other voices comprise the accompaniment. To further emphasize a sense of community, Bennett switches between first person singular and plural pronouns. She herself seems to make certain assertions as author, while at other times she participates in a somewhat nebulous "we." When discussing the literary club in Boston Bennett says, “This Quill Club interests me" (October 1926, 322). Yet when addressing a racist letter about the play Lulu Belle, she uses the communal "we" in order to emphasize that she is speaking on behalf of the African American community to combat racism (323). 
For the most part Bennett's writing style is conversational, relaxed and meandering. Her superficial informality, however, masks underlying rhetorical motivations. In October 1926, Bennett quotes a letter from William Stanley Braithwaite who attests to the readability of the column: "You have made The Ebony Flute attractive and interesting and I am looking forward to each month as a sort of personal chat with you about books and things" (322). The "personal chat" in written form is exactly what Bennett develops in "The Ebony Flute." She makes use of quick transitions, never dwelling too long on a single topic, so that the reading of the column is an experience of jumping from one subject to the next in a stream-of-consciousness style. Her transitions may consist of nothing more than, "This reminds us..." She makes frequent use of the ellipsis and the dash, pausing often and interrupting herself. Bennett's purposeful and meticulous attention to language in her poetry is obvious in her prose as well, which is poetic and even lyrical at times. Of course, Bennett's poetic sensibility would not allow an inattention to the uses and the power of language in whatever genre. Bennett consciously constructs a voice and persona in "The Ebony Flute" that encourages a casual familiarity and rapport with her intellectual black readership.

In "The Ebony Flute” Bennett engages her black readership by using peformative language. An article entitled "Characteristics of Negro Expression" written by Zora Neale Hurston in 1933 describes dramatic and performative aspects of African American expressive culture that appear in language, dialect, dancing, folklore, and sexuality. She explains the rich dramatic culture that infuses everyday life: "Every phase of Negro life is highly dramatized. No matter how joyful or how sad the case, there is sufficient poise for drama. Everything is acted out. Unconsciously for the most part of course. There is an impromptu ceremony always ready for every hour of life. No little moment passes unadorned" (Hurston 294). This "adornment" and 
"ceremony" also occurs in language, Hurston notes. For the African American writer, creative figures of speech and rhetorical flourishes are commonly used as part of a linguistic performance. Describing the ways in which writing can be performative, Hurston explains how the words of black authors can be infused with action: "His very words are action words. His interpretation of the English language is in terms of pictures. One act described in terms of another. Hence the rich simile and metaphor" (293). This active, pictorial language signifies experiences beyond the immediate meanings of the words themselves. Certain expressions of comparison and figures of speech comprise a mode of cultural expression and a common way of viewing the world.

In defining her column as a forum for "literary chit-chat and artistic whatnot," Bennett informs the reader that her subjects will be literature and art, but she seems to downplay the seriousness of her project by using the terms "chit-chat" and "what-not" to describe her subject matter. This is partly a reference to her genre, although the more serious social issues Bennett addresses would not be found in the social "gossip columns" that appeared in newspapers at the time. The reader should not be fooled into supposing that Bennett's column consists of frivolous marginalia. Using the words "chat-chat" and "what-not" is a performative gesture that allows Bennett to connect with her audience on a less formal and more intimate level. Bennett covers a variety of subjects in her column from art and literature to gossip about members of the Harlem elite to examples of racism and prejudice. Regardless of her subject matter, however, Bennett wants the reader to feel as if he or she is engaged in a friendly and informal chat with the author. She works to make her tone warm and accessible, while using references and language which appeal to her Harlem readership. 
Throughout the column Bennett relies on performative language in the form of colloquial expressions, deep description, rich metaphor, and gossip. Especially in the opening and closing sentences of her column, Bennett draws in her reader by using colloquial phrases or referencing common experiences or sources. For example, Bennett ends her June 1926 column, “And so another moon has passed and the world do move..." (183). This expression is often associated with sermons of African American preachers and signifies an ever-changing world. At the conclusion of the May 1928 column, Bennett quotes an old African proverb read by Opportunity editor Charles S. Johnson during a radio broadcasting hour: "If you would tell anything to heaven, tell it to the wind" (153). Bennett comments on the "vast prophetic quality" of this statement, falling as it does at the conclusion of a radio broadcast. Bennett's language can generally be characterized by its formality and broad vocabulary, but also whimsy and playfulness. When she uses colloquial phrases or sayings, she usually sets off the language in italics to draw attention to it. Bennett uses idiomatic phrases that her readers would likely recognize, yet she visually sets them apart from the rest of her prose. Her writing style displays her authorial persona as a modern and sophisticated writer who weaves traditional language and phraseology into her writing practice.

Bennett also uses literary references which her readers would likely recognize. She begins and ends her October 1927 column with a reference to the opening lines of Helen Hunt Jackson's poem "September," which read, "The golden-rod is yellow; / The trees are turning brown; / The trees in apple orchards / With fruit are bending down” (308). Bennett's opening line uses this phrasing to indicate the changing of the seasons and to introduce her purpose in the column: "Now that the golden-rod is yellow and the corn is turning brown, we shall get us to this business of what's what among dusky folk" (308). Bennett imagines that her readers would 
recognize this seasonal poem by Jackson, a well-known advocate of Native American rights and close friend of Harriet Beecher Stowe, author of Uncle Tom's Cabin. The following month she begins her column: "Everything seems all agog among dusky cliff-dwellers these days" (November 1927, 339). In referencing herself and her cohorts as "dusky" she draws upon a common adjective to describe African Americans, one that was generally considered to be more acceptable than "darky." "Cliff-dwellers" likely refers to Bennett's urban readership and their residence in tall buildings. Through these references, Bennett encourages modern readers, artists, and writers to identify with the long and diverse history of African expression and creativity.

Bennett often uses figurative language and extended metaphors when referencing her column project, playing upon the ebony flute of the column's title whenever possible. She quotes several poems that reference flute music, "pipes a shrill note on a flute of ebony" in memory of a friend who has died (November 1926, 358), and keeps "staccato time with only now and then a melodic break in the shrill purpose of our song" (August 1927, 242). Bennett uses the flute and its music as a metaphor for the mood and tone of her writing in the column. In her first column after quoting Benet's poem, "Harlem" from which Bennett drew the name of the ebony flute, she reflects, "And on through line and line of beauty that coins a Harlem as a poet would see it, lush and colorful...fertile like rich earth" (260). This simile is significant for its presentation of Harlem as a fertile and productive space for creative endeavors, which Bennett emphasizes in "The Ebony Flute." In the August 1927 column, a year after the debut of "The Ebony Flute", Bennett compares the role of author and written work to the relationship between parent and child, describing herself as "fond parent" celebrating the first anniversary of her "brain-child." She even designates Benet as "godfather" of the column (242). Describing the column as a living child reminds the reader of Bennett's active role in its creation and maintenance. Speaking of a 
literary column figuratively as a child or an instrument attests to the dynamic role "The Ebony Flute" plays in the relationship between author and reader.

In addition to colloquial phrases and figurative language, Bennett uses gossip as a community-building gesture in "The Ebony Flute." Chad Bennett discusses the ways in which gossip is performed and involves speaking as well as listening. The figure of the gossip "vacillates between a particular busybody and the disembodied voice of everybody, between a person and a thing, a tale and a tone, talking and listening” (318). By engaging in gossip Bennett demonstrates her belonging in a community and her ability to both listen and convey information in a particular style. For Chad Bennett the significance of gossip as a devalued art goes beyond the actual words spoken and involves the theatrical style and tone in which they are delivered, which the gossip may imitate from others. Bennett says, "It has been an exhilarating task to chronicle the gossip of Negro writers, singers, and players" (August 1927, 242). She addresses personal details about the who's who of the Harlem literary and arts scene, mentioning for example the marriages of Aaron Douglas and Countee Cullen: "But by far the most important thing about Mr. Douglas these days is his new wife" (August 1926, 260), and the opening line of her May 1928 column reads, "By far the most important thing that has happened in the literary world during the last month is the marriage of Countee Cullen to Yolande DuBois" (153). In both instances she is careful to cite the importance of these personal happenings, attesting to the crucial role gossip plays in her column project. Bennett often includes information about the travels of various people, such as Jean Toomer's trip to France and Countee Cullen and father's visit to Europe. She relays a charming anecdote about Dr. Rudolph Fisher, who had taken to calling his baby "the New Negro" (August 1926, 261). Notably, the gossip Bennett conveys is 
not malicious, as her purpose is establishing alliances and race-building. However, Bennett employs the trappings of the juicy tale, drawing in her reader and developing an intimate rapport.

One of the most scandalous pieces of gossip Bennett mentions involves popular entertainer Josephine Baker. Baker is mentioned in Bennett's column upon the event of one of her most brazen publicity stunts, her supposed marriage to her publicist, the so-called Count Pepito d'Albertini. In the August 1927 edition of "The Ebony Flute," Bennett describes the happy event:

The altogether remarkable 'Jo' has done the inimitable again... according to the New York Morning World for June $27^{\text {th }}$ she has become Countess d'Albertini...in Europe she has been exposed to royalty and in the manner of the true stage darling has captured one of the nobility in matrimony...her words on the subject are gems: 'He sure is a count-I looked him up in Rome. He's got a great big family there with lots of coats of arms and everything.' (242)

It was later discovered that the marriage had not in fact taken place, nor was Pepito in reality a count. However, if accounts like Bennett's were the goal of this scheme, then it succeeded. The concept of an African American entertainer and a member of European nobility united in matrimony comprised a sensational story for the papers.

In conveying this juicy tidbit as well as other personal details, Bennett not only demonstrates her influence as an insider, but she takes on the role of a gossip, one who possesses a form of social currency and performs as a storyteller. In "The Ebony Flute" Gwendolyn Bennett satisfies both parts of Chad Bennett's definition, taking on the dual role of the "particular busybody and the disembodied voice of everybody" (318). She develops a unique 
performative voice and persona that imitates the spoken word, presenting the intonation and gestures of speech. Bennett constructs a singular voice that engages with and speaks for her community.

\section{The Darker Side of "The Ebony Flute": Countering Racism and Negotiating Primitivism}

In "The Ebony Flute" Bennett focuses primarily on racial uplift in the form of artistic accomplishment, as her flute resounds with a bright, energetic melody. Yet her composition includes solemn and mournful interludes. Occasionally, Bennett directly exposes the ugly underbelly of racism and violence that comprises the reality of African American lives. In the October 1926 column, directly after addressing the best line in Negro poetry and quoting the poem, "Dark Dancer" in its entirety, Bennett quotes excerpts from a disturbing letter by Katherine Metcalf Roof that appeared in the Herald-Tribune. Roof was apparently responding to a letter from another reader who criticized those who took the popular musical Lulu Belle to be representative of the race. Roof baldly states that if she were a Negro, she would enjoy her natural "dramatic gifts" rather than aspiring to a higher education. According to Roof, "the very genius of the colored race" is the "soul-stirring beauty and subtle humor of the music and folklore" and "artists" like Booker T. Washington, Paul Lawrence Dunbar, and Paul Robeson "are far too wise to release their hold upon them (dramatic gifts) with higher education" (323). Bennett responds to this writer's ignorance by musing about whether Roof knows how educated and "college-spoiled" many of the people she listed are, and mentions, among others, Paul Robeson's Phi Beta Kappa key and law degree.

Although racism always undergirds Bennett's writing in "The Ebony Flute" she takes this opportunity to tackle ignorance head-on in the attitude of Katherine Roof, which was shared by 
other white people at the time. While appearing to compliment African Americans for their "natural" musical and dramatic abilities, she insults them by suggesting that an education is unnecessary and even presumptuous. In a rhetorical move that surely rankled Bennett and other educated African Americans, she presumes to claim that if she were black she would not seek an education but would instead glory in her natural dramatic abilities. The danger in this type of reasoning stems from a fear of African American academic accomplishment and the social power that accompanies education. If seemingly well-meaning whites praise performative abilities as their best and only necessary pursuit, African Americans can be kept safely and happily in ignorance and out of universities.

Bennett closes this useful discussion with what seems like a pithy dismissal but is in fact blistering condemnation of racism and of the inability to understand the significance of education and art. She sums up, "But why battle about things like this...so long as black is black and the moon comes up on the left we have people who measure art by a rule of thumb and beauty by the length of a word" (323). As Bennett demonstrates by devoting several paragraphs of her limited space in the column to this issue, it is very much worth battling about. As is often the case when she addresses important social issues, barely disguised beneath Bennett's light prose is biting criticism. Bennett condemns those who essentialize black accomplishment and minimize the significance of education. In cataloguing the successes of African Americans in art as well as formal education in her column, Bennett attests to the inherent connectivity between the two pursuits and their ability to actively combat racism.

However, in her efforts to unite diverse communities there are also moments in "The Ebony Flute" when Bennett defends the work of white writers from the condemnation of black reviewers. Notably, Bennett repeatedly praises Carl Van Vechten's Nigger Heaven, which was 
criticized by influential figures in the black community such as W. E. B. DuBois, who felt that in his intimate knowledge of the black community Van Vechten was releasing cultural secrets he had no right to know in the first place. Van Vechten even goes so far as to include a "Glossary of Negro Words and Phrases" in Nigger Heaven to invite outsiders into a body of specialized knowledge. In exposing this counter discourse some felt Van Vechten was appropriating and manipulating a powerful linguistic code that heretofore was little known by white readers. Bennett disagrees, endorsing the book several times in "The Ebony Flute" and calling it a “perfect piece of research work” (September 1926, 292). In her April 1927 column Bennett defends Van Vechten's character and intentions:

There are many who would accuse Van Vechten of mere exploitation in his relations with Negroes prior to the appearance of his book about them. This is not true, for Mr. Van Vechten can cite example after example of Negroes for whom he has a lasting friendliness...there are, too, a goodly number of Negroes to whom he has rendered invaluable service towards the achievement of those things their hearts have held dear. His has been a rather intimate knowledge of this little understood people... (122)

If Bennett's main purpose in the column is to define and broaden the reach of the Harlem Renaissance through exposure to literature, art, and performance, she must champion any writer or artist whose work makes a significant and positive contribution to racial understanding. This is yet another example of her inclusive approach; she openly encourages "friendliness" and "service" between people of diverse backgrounds who strive toward a common goal. 
For Gwendolyn Bennett and her cohorts, participating in the arts and education and encouraging others to do so was a crucial task. Many black intellectuals believed that accomplishment in art and literature would lead to equality with white people. Steven Watson explains that the younger generation of Harlem Renaissance writers "constituted the first selfconscious black literary constellation in American history" (9). The responsibility of racebuilding, then, fell on these young writers and artists like Bennett, who were "simultaneously charged with creating art and bolstering the image of their race" (Watson 9). This was a complex task, however, as African American authors, artists, and entertainers were often defined by their "natural" dramatic abilities and native exoticism.

White as well as black visual artists and writers during the New Negro Renaissance often conflated the African American subject with his or her "primitive" identity. An imagined connection with African roots placed black Americans outside of "civilized" culture. Caroline Goeser explains: "In venues from advertisements to popular books, blacks were too frequently presented as brutish savages or docile primitives. In more progressive assessments of black identity, non-black writers would often reveal a romantic nostalgia for the noble savage, wishing that contemporary blacks fully retained what they defined as their innate primitive heritage" (24). This stereotyping of black Americans allowed white Americans to easily categorize and essentialize them to make sense of their music and art. The "noble savage" is notable as a romanticized and idealized construct, a non-threatening figure who is to be lauded for possessing a nature unspoiled by modernity. More often, however, white culture associated this "natural state" of African Americans with liberation and licentiousness, as Harlem culture became the repository for indulgence of the baser instincts. Reflecting on the Harlem Renaissance in 1950, 
William Gardner Smith explains the phenomenon of early twentieth century white fascination with African culture:

The wildness of youth is akin to savagery, marked by the absence of many inhibitions, the absence of many taboos. And what segment of the American population was believed to be closer to this 'natural state' than the Negroes? If it was a time for singing, a time for dancing, a time for sin and sex, then it was a time for kinship with the American Negroes_-particularly that wild and charming breed spawned in the tenements of Harlem. What did it matter that Negroes were not, really, any closer to savagery than the white American? What did it matter if the vision of the Negro as native existed only in the chauvinistic white mind? The belief was enough. The symbol sufficed. (292)

Gardner explains that in the freethinking and modern context of 1920s white America, the time was ripe for association with what white Americans perceived as the wildness of black Harlemites. It is crucial to note that these attitudes led to the construct or "symbol" of the savage; Gardner stresses that although these stereotypes of black Americans existed only within the minds of whites, their power to tantalize and entice drew many white Americans to Harlem.

In 1926 a drawing by Bennett appeared on the cover of Opportunity that is indicative of one of the major cruxes of the New Negro Renaissance: black identity and primitivism. Bennett did wear many hats at Opportunity, contributing poetry and illustrations as well as serving as assistant to the editor. The piece features a modern black woman in evening dress with a rosette at her hip against a dark background. Behind the woman in the bottom half of the illustration Bennett includes a frieze that features three female figures in relief. One is naked and the other 


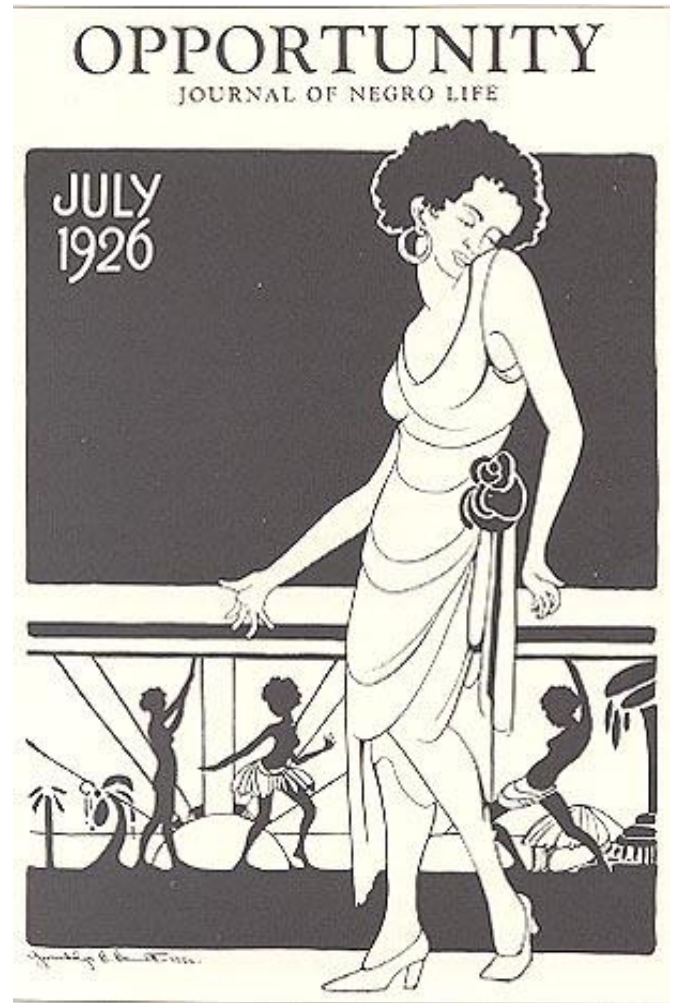

Figure 2.2: Gwendolyn Bennett, cover of Opportunity, July 1926 two are topless; they dance in a tropical setting in front of what appears to be a rising or setting sun. The modern black woman stands in a languorous attitude in juxtaposition to the figures in the frieze. The woman appears in the foreground, separated from the "primitive" figures, yet her expressive hands and shrugging shoulder suggests that she experiences the same impulses as the women in the frieze; she feels the same tempos and rhythms in her blood. The figure is at ease, eyelids drooping sensually and knee bent as if she sways with un unheard rhythm. While the figures in the frieze appear in flat relief, like a painting or carving, the woman's attitude is more suggestive and active, a modern liberated figure with her own agency. She draws energy and inspiration from her counterparts in the frieze, the exoticized African figures.

Within the African American community some embraced the portrayal of a primitive African past and others rejected it as propaganda. Still others such as Aaron Douglas, another graphic artist who contributed to Opportunity, turned the stereotype around to create what Goeser calls a "new primitivist discourse" (25). Interpreting the in-betweenness of African Americans as a position of power rather than weakness, Douglas's art expressed that "black Americans could contribute to modern American culture by reconnecting the primitive and civilized, the past and present, from a strategically interstitial position as a welcome 'compound of the old and new"' (Goeser 25). Perhaps this interpretation could also be applied to Bennett's drawing above. Jerry Langley and Sandra Govan highlight the subject of Bennett's piece in 
terms of the primitivist bent in art: "The illustration voices the Renaissance fascination with the 'primitive' and the exotic and indicates the unity of African and African American heritage while conflating implications of identity and alienation with the Harlem cabaret - the music and the dance and the dancers" (9). While it is certainly true that the drawing channels the cabaret, a space that the white imagination associated with the primitive impulses of black bodies and music, perhaps the position of the modern black woman can be seen as simultaneously a position of alienation but also of power. Her dress and attitude are suggestive of modernity, yet she also seems to channel the energy of the liberated figures in the frieze. Because she dwells in the “interstitial space” Goeser describes, she unites Africa and America.

In 1923 Gwendolyn Bennett's poem "Heritage," which had previously appeared in The Crisis, was published in Opportunity. This poem can be seen as a narration of the above illustration, alluding to the same impulse of reaching into an imagined space for a sense of racial belonging:

I want to see the slim palm trees,

Pulling at the clouds

With little pointed fingers...

I want to see lithe Negro girls,

Etched against the sky

While sunset lingers.

I want to hear the silent sands, Singing to the moon

Before the Sphinx-still face... 
I want to hear the chanting

Around a heathen fire

Of a strange black race.

I want to breathe the Lotus flow'r,

Sighing to the stars

With tendrils drinking at the Nile...

I want to feel the surging

Of my sad people's soul

Hidden by a minstrel-smile. ("Heritage")

Emotionally, this is a poem of longing for an idealized place of racial belonging. The repeated refrain "I want" refers variously to a number of sensory experiences: "to see," "to hear," "to breathe," and finally "to feel". The speaker imagines a series of soothing images and sounds associated with the stereotypical African motherland. The palms, the sunset, and the sands paint a picture of a space where nature richly abounds, far removed from the grit of urban Harlem. "Lithe Negro girls" appear "etched against the sky" in relief, as in Bennett's illustration. Significantly, Bennett's imagined female African figures appear as one-dimensional shadows against a bright background.

While the exotic setting of this highly anthologized poem is certainly crucial, I am more interested in the performative qualities it illustrates. The mood of yearning to escape builds throughout the poem, climaxing with the reference to the "minstrel-smile," the only reference to the speaker's current place of dislocation and suffering. The "minstrel-smile" is a necessary performance that masks the "surging" of the soul, a verb that suggests the powerful damming of 
flood-waters. The speaker in "Heritage" laments the lampooning of African Americans by white people that occurs in these shows. She also wishes to strip away the minstrel mask and understand the true suffering of her "sad people's soul." The minstrel show was often comedic and the characters wore large clownish smiles, belying the history of violence and oppression African Americans had endured. The minstrel show highlights the performativity of race, especially within a specifically theatrical context.

In their anthology African American Performance and Theater History, Harry J. Elam Jr. and David Krasner assert that "the American race question is inherently theatrical" (4). Elam explains, "Definitions of race, like the processes of theater, fundamentally depend on the relationship between the seen and the unseen, between the visibly marked and unmarked, between the 'real' and the illusionary" (4). Both race and theater are built upon and depend upon the use of devices. Elam acknowledges the historical association in the Western world of black skin with "intellectual inferiority and cultural primitivism" (4), not to mention hyperembodiment. As seen in the assertions of Katherine Metcalf Roof in "The Ebony Flute," this association of the black body with the corporeal leads to blacks' supposedly "natural" performative and theatrical abilities. However, Elam argues that black performers can use what he calls their "ambivalent status" to "transgress, transcend, and even subvert established racial categories" (14). Black performers can assume a position of power to "expose" and possibly "explode" stereotypes and definitions of blackness (14). By exposing the very theatricality of race and the constructions and devices it employs, black performers, artists, and writers can productively call attention to and undermine harmful stereotypes.

In "Heritage" Bennett simultaneously invites and upends primitivism. She appropriates the primitivist stereotype that has been developed by white culture and embraces its possibilities 
for black identification. Bennett draws upon a stereotypically primitive setting in the poem with references to a "palm tree," the "Sphinx," a "Lotus" and the "Nile." Her reference to "heathens," “chanting," and "a strange, black race" are undoubtedly drawn from white stereotypes of black savagery. However, Bennett's speaker reclaims these places and images and longs to insert herself into this scene. More importantly, she opens new possibilities for black performativity and desire that are distinctly separate from the minstrel show and similar theatrical contexts in which white culture dictates and regulates the behavior of black performers. Elin Diamond defines performances as cultural practices that "conservatively re-inscribe or passionately reinvent the ideas, symbols and gestures that shape social life" (qtd. in Elam 9). Elam asserts that these "performances of everyday life have been critical to black cultural expression, struggle, and survival" (9). In "Heritage" Bennett draws upon cultural and social symbols to reinvent and reposition performativity for African Americans as an act of identification rather than alienation.

\section{Theatrical Performance in "The Ebony Flute"}

The works of accomplished black musicians and dancers comprised a crucial part of the Harlem Renaissance, and in "The Ebony Flute" Bennett devotes considerable attention to the work of well-known figures such as singers Paul Robeson and Ethel Waters, composer Edmund T. Jenkins, and dancer Josephine Baker. Bennett draws distinctions between African American conceptions and articulations of their own dance and perspectives that came from outside of Harlem. For example, in November 1926 Bennett includes an amusing excerpt from the Encyclopedia Britannica's record of $20^{\text {th }}$ century Negro dances:

In 1925 there arose an entirely new type of ballroom dancing known as the Charleston. Negroid in origin, its peculiar and strenuous steps aroused some 
misgivings on the part of the medical profession as to the danger to the body caused by excessive strain on the muscles subjected to constant distortion. Public endurance contests were often the scene of complete breakdown on the part of the participants, sometimes with permanent injury. (357)

By 1926 the Charleston was already dying out, as it was "too ungracefully violent to remain popular." While these medical "misgivings" as to the physical effect of the Charleston appear quaint and unscientific to modern readers, this excerpt provides an interesting perspective from the authoritative and established Encyclopedia Britannica. The reference book's description of the Charleston as violent, awkward and even physically dangerous, as well as "Negroid," is an unmistakable condemnation of black movement and black bodies from white authorities.

Further, while the origins of the Charleston are thought to stem partly from traditional African dance, the 1920's craze was a hodgepodge of different dance styles and was first associated with white flappers. The Encyclopedia Britannica places the blame for this unfortunate dance phenomenon squarely on African Americans, while the article minimizes the social importance of the dance and fails to address its cultural impact, which can perhaps better be interpreted in retrospect. For many, the Charleston, often associated with female performers, represented immorality and sexual freedom. It undoubtedly marked a watershed moment in American history when sexual mores were changing and city-goers were visiting speakeasies. The encyclopedia article focuses myopically on the physical movements and exaggerates the bodily dangers. The real danger here of course is the black bodies and the female bodies that seductively move to such a scandalous rhythm. 
The role of the black woman within rubrics of racial uplift was complex and often contradictory, as she was left to the task of negotiating the Old and New Negro identity. Within the African American community, black women were expected to be demure and asexual to counter stereotypes of the exotic, lascivious negress. They also had to contend with the image of the selfless, nurturing Mammy. The assumptions about the sexual and moral character of black women were deep-seated and took on a particular class dimension. Anne Stavney notes that "while white women of similar educational and sociological background were trying to throw off sexual restrictions, black women were defending themselves against racist allegations of sexual immorality" (537). Even while attempting to counter harmful stereotypes, black women also bore the burden of upholding the purity of the race. The roles women were expected to take on within the black community were similar to the nineteenth century white cult of true womanhood, with motherhood and homemaking as its defining characteristics. Black women were not only expected to maintain their sexual purity while bearing children and maintaining an ideal domestic space, but they also played a crucial role in racial uplift. The African American home became a microcosm of society, representative of the most civilized aspects of black culture. Accordingly, the black woman and mother not only educated her children, but she was also responsible for upholding the dignity, respectability, and moral values of the race.

While the ideal of African American womanhood was upheld, black female performers and dancers were criticized for exploiting or fetishizing their sexuality for economic gain. Since black women were already stereotyped as exotic and oversexed, for many respectable middleclass African Americans, dancers were undermining the efforts against racism by inviting the objectification of the black female body as "women once again became bartered flesh, to be observed and mastered" (Krasner 62). However, many also viewed these women as positive 
symbols of the race, as liberated individuals who threw off the constraints of sexual decorum while effectively mocking harmful stereotypes. According to James F. Wilson, these women "played the stereotypes to the enjoyment of both black and white audiences, and with the assistance of their white or black creators, they often satirized, exaggerated, or poked fun at these depictions. They merged elements of primitivism and modernism and attempted to realize the goals of cultural pluralism and social uplift" (153). In a complex representational economy, black female performers took advantage of the image of the primitive and sexual African and used it as a position of power to bring visibility to issues of racism and sexism. By highlighting the lives of black female entertainers, authors, and public figures regularly in her column Bennett examines the phenomenon of fame and brings attention to these representational paradoxes.

For example, in March 1927, Bennett comments on and quotes from Carl de Vidal Hunt's article on Josephine Baker that appeared in the New York World:

There is much tom-foolery in the article about her undying belief in the power of a rabbit's foot and a good deal of misstatement about the company with which she first appeared in Paris, but even this rather uninformed writer arrives at this beautiful conclusion about a Negro girl, whose rise to envied stardom in the music halls of Europe, has been so phenomenal: ... 'Her lithe, young body, looking like a Venetian bronze come to life, seemed to incarnate the spirit of unrestrained joy. It is a wild thing, yet graceful and harmonious - a demon unchained, yet delicate in its sleek, symmetrical beauty' (90).

Bennett qualifies her laudatory comments on the article by noting that the author attributes "tomfoolery" about native superstition to Baker, but she is charmed by his description of her dancing, 
peppered as it is with descriptive adjectives. Baker is simultaneously "wild" and a "demon" yet also "joyful," "graceful," and "harmonious." The description, even praising Baker as it does, smacks of primitivism. Indeed, for many Baker's developed persona represented the commercial and social success black entertainers could attain by playing upon primitivist stereotypes.

Clad only in feathers or in her famous banana skirt, Baker stunned audiences with her exotic and overt sexuality; her performances brought African American vaudeville to Paris. ${ }^{10}$ As Baker became a rising star in Paris her public image was very carefully constructed. Bennett notes that she "loves clothes...it seems a divine twitch of fate that at present she wears only clothes designed by Paul Poiret, one of the world's greatest designers for women" (March 1927, 90). Tyler Stovall describes her "draped in jewels and furs" and "strolling boulevards with her pet leopard" by day, while by night she was "chauffeured in a snakeskin-upholstered limousine from one lavish party to the next" (55). She became an international trend-setter, as women strove to imitate her hairstyle and skin tone. Undoubtedly, Baker developed a complex and contradictory public image: the sophisticated savage. She drew upon the tenets of primitivism in her dress and dance, taking advantage of the stereotypical oversexed and exotic African temptress as her persona. Baker demonstrated that this image could be exploited for power and economic gain.

While Baker glowed under spotlights, however, a very different mode of cultural performance was being enacted upon a very different stage. In her column, Bennett presents the fetishized bodies of celebrity performers who achieved commercial success, but she also acknowledges the darker side of racial performance - the violence enacted upon defenseless black bodies in performative contexts. In her column in August 1927 Bennett recounts a meeting with French author Rene Maran during which he shows her an article on lynching published in a 
French newspaper. He expresses solidarity with Bennett and her American cohorts as "he, himself, was incensed at the idea of such barbarity and told me that in a like manner the white Frenchman could in no way understand the toleration of cruelty in a civilized community." For Bennett, "It was a beautiful thing to note the kindredship that existed in his heart because of the irradicable black of our skins" (243).

Critics have made clear that there are many ways to imagine lynching as performative. Michael Hatt positions lynching as a mode of performative ritual in which "the process of naming the victim, parading him through the streets, forcing a confession, and then torturing and killing him, followed by the desecration of the body, took the place of any verbal procedure of establishing guilt and justifying punishment in moral terms" (80). In other words, the performative nature of lynching substituted the gestural for the verbal, satisfying those who were threatened by blacks and wanted to see them dehumanized (80). Lynching is an act that ritualizes and materializes violence and terror, maintaining and strengthening white supremacy. Koritha Mitchell posits that for African Americans, lynching is understood as a white response to black achievement and success. She places lynching in a theatrical context, where whites perform their master status by degrading and fragmenting the black body (3). Even photographs of lynchings, Mitchell argues, do not simply document the event but in fact continue the performance.

In "The Ebony Flute" Bennett presents cultural as well as theatrical performances in order to establish black solidarity and invite readers to identify with a common history. The discussion of lynching is crucial because it transforms a cultural performance into a theatrical performance. Mitchell explains, 
African Americans interpreted lynching as a master/piece theater. That is, when real life lynchings became theatrical, whites literally used pieces of black bodies as props to perform their master status. In other words, African Americans viewed lynching as a theater of mastery in which whites seeking (not assuming) racial supremacy used the black body as muse, antagonist, and stage prop...Thus, if white supremacists denied black humanity, black familial ties, and achievement, African Americans must have been convincingly establishing it. (3)

There is no question that the specter of the violated black body lurks behind the curtain in Bennett's celebration of black theatrical and cultural performance. Despite her often light hearted commentary and informal language, her readers know what is at stake. As Mitchell asserts, however, whites felt the need to assert and perform their "master" status because their position was threatened by black success. Through the eyes of white supremacists in their "theater of mastery", the black citizen becomes "muse, antagonist, and stage prop," performing the dehumanizing roles that whites assigned. This is why Bennett's focus on performance is crucial in "The Ebony Flute." In touting black achievement and culture, she combats historical and present violence against the African American body and spirit.

Much of Bennett's legacy lies in her leadership and involvement in organizations and her championing of young African-American artists and writers. In 1935, Bennett was one of the founding members of the Harlem Artist's Guild and served for a time as the director of the Harlem Community Art Center, an influential if brief project funded by the Works Progress Administration under Franklin D. Roosevelt. The center provided education in the arts for young African Americans and it is where many artists had their start. The project garnered much publicity, including a visit from first lady Eleanor Roosevelt at its opening. The center only 
lasted 16 months but contributed to the founding of the Harlem Arts Alliance, housed in the same space on Lenox Avenue and still in existence today. Bennett's affiliation with the organization ended when the WPA was attacked for communist activity and Bennett herself was investigated by the Federal Works Agency for associating with reported communists. Despite these setbacks, Bennett continued her activism, serving on the board of the Negro Playwrights Guild and co-founding the George Washington Carver Community School.

Her early work in Opportunity established Bennett as an important writer of the Harlem Renaissance and cemented her reputation as a champion of black art and literature. In covering her beloved "literary chit-chat and artistic what-not" Bennett draws in her Harlem audience by creating an intimate performance space where she develops a relatable voice and speaks freely of the achievements and setbacks of the African American community in Harlem and beyond. Focusing on expressive culture, Bennett draws upon theatrical as well as cultural performances that define the black community and highlight a diverse history. Emphasizing the progress that African Americans made in the face of daunting prejudice, Bennett celebrates the buoyant and insuppressible African American spirit, this euphoric "hurricane joy" described by Benet, which exists even in the midst of the "dumb despair" of oppression and violence. 


\section{Notes}

${ }^{1}$ A painting of Gwendolyn Bennett's has recently been discovered by Belinda Wheeler. See "Scholar Discovers the Only Known Painting of the Harlem Renaissance's Gwendolyn Bennett."

${ }^{2}$ Edwards cites Paul Gilroy’s contributions to discussions about abstractionism vs. antiabstractionism in diasporic dispersal in Tommy Lott's "Black Cultural Politics: An Interview with Paul Gilroy.”

${ }^{3}$ These are called "overlapping diasporas" by Earl Lewis in "To Turn as on a Pivot: Writing Americans into a History of Overlapping Diasporas."

${ }^{4}$ The term "theater of mastery" is used by Koritha Mitchell in Living with Lynching.

${ }^{5}$ See the following articles by Govan: “After the Renaissance: Gwendolyn Bennett and the WPA Years” (1988), “Kindred Spirits and Sympathetic Souls: Langston Hughes and Gwendolyn Bennett in the Harlem Renaissance,” (1995), “A Blend of Voices: Composite Narrative Strategies in Biographical Reconstruction,” (1997), and Langley and Govan, “The Richest Colors on her Palette, Beauty and Truth” (2010).

${ }^{6}$ See Chaney, “Traveling Harlem's Europe: Vagabondage from Slave Narratives to Gwendolyn Bennett's 'Wedding Day' and Claude McKay's Banjo.”

${ }^{7}$ See Garcia, "Black Women Writers, Modernism, and Paris."

${ }^{8}$ See Johnson and Johnson, Propaganda and Aesthetics: The Literary Politics of Afro-American Magazines in the Twentieth Century and McHenry, Forgotten Readers: Recovering The Lost History of African American Literary Societies.

${ }^{9}$ Gwendolyn Bennett: The Harlem Renaissance’s Quintessential Poet, Artist, Editor, and Columnist, forthcoming from the University Press of Mississippi. 
${ }^{10}$ Baker's Broadway debut occurred in 1921, when she played a chorus girl in the popular musical Shuffle Along. From there Baker performed in popular venues such as the Plantation Club in Manhattan and was later recruited to perform in France, where she starred in the Revue Negre and the Folies-Bergere. 


\section{Chapter 3}

"Whadda you think this is—a dress rehearsal?":

Performance and Metatheatricality in Edna St. Vincent Millay's Aria da Capo

In 1936 Elizabeth Atkins commented on Edna St. Vincent Millay’s widespread international popularity and encompassing influence: "Everyone recognizes that Edna St. Vincent Millay represents our time to itself [...] She is the only living poet who is casually quoted in philosophical treatises and in moving-picture magazines, in churches and in nightclubs, in the rural schools of Oregon and in the Sorbonne of Paris" (vii). What a great privilege and burden for a writer to represent a time to itself, particularly in both scholarly and popular contexts. In order to represent a time to itself, a writer must reflect what is most poignant in society, challenge social mores and values, and articulate political realities as well as enact aesthetic ideals. The fact that Millay's work was quoted and appreciated in such a wide variety of mediums during her lifetime attests to both the broad appeal of her poetry and the power of her celebrity status.

Millay developed a poetic style that sparkled with wit and brimmed with sexuality. Many were drawn to her poetry out of curiosity, as much of it is intensely autobiographical. ${ }^{1}$ Millay's verse not only explores the vicissitudes of love and longing, but espouses the feminist ideals of personal liberty and sexual autonomy associated with the "New Woman" of the previous generation. Millay's work is notable in that it combines modernist ideas with traditional form. Nina Miller describes Millay's verse as “equal parts transgressive and traditional” (17). Millay's greatest literary influences included sixteenth and seventeenth century English poets such as Shakespeare and Milton. Millay favored the sonnet and other traditional poetic forms, yet her 
Bohemian lifestyle, feminism, and political interests comprise the content and focus of her work and were also expressed in her role as actress and performer of her poetry.

Millay's performative persona and popularity is described by Millay biographer Nancy Milford, who compares Millay's dynamic presence and poetic appeal to that of Byron, who represented the notion that "the poet in his person was the romantic ideal" (xiv). Performance was an integral part of Millay's poetry, and Milford explains the uniqueness of Millay's allure: "Edna Millay was the only American woman to draw such crowds to her. Her performing self made people feel they had seen the muse alive and just within reach. They laughed with her, and they were moved by her poetry. Passionate and charming, or easy and lofty, she not only brought them to their feet, she brought them to her" (xiv). This magnetism coupled with the seductive power of her poetry drew people in and entranced them.

Despite her impressive accomplishments and accolades, which included five honorary doctorates and the distinction of being the third woman to win the Pulitzer Prize for poetry, in the decades following her death in 1950, Millay was often construed in the public eye rather narrowly as a lyric poet whose verse was sometimes described as adolescent and immature, focusing mainly on romantic or erotic themes. Indeed, in later generations, Millay's name came to be associated with "bad art," and poets such as Anne Sexton expressed reservations about being compared to Millay whose verse was seen as excessively emotional and sentimental. Artemis Michailidou has noted that although Millay’s poetry was once hailed for its originality, by the 1950s and 60s her verse was seen as "little more than an immature articulation of the poet's personal (and, primarily, erotic) experiences" (118). Other critics have indicated that Millay's poetry is neither modern nor subversive. ${ }^{2}$ Millay's poetry proved difficult to categorize, 
as her traditional use of form and the popular appeal of her work placed it outside the scope of high modernism.

However, a closer look at Millay's canon reveals a much more nuanced writer straddling the line between a modernist and sentimental aesthetic. Her formalism does not indicate a lack of intellectuality or an outright rejection of modernist aesthetics. Joseph Aimone characterizes Millay as a "carefully modern stylist" and even "a postmodern eclectic user of verse forms archaic and recent, unbenighted by simpleminded wholesale rejections of traditional form" (4). Jo Ellen Green Kaiser explains that while many of her poems were written in traditional forms such as ballad and stanza, in poems such as "Spring" Millay employs modernist technique and experimentation; however, she never ascribes to a "classic modernist position," defined by a fragmented modern world in crisis and a turn to myth. The modernist ideology described by Kaiser is based on Eliot's "Tradition and the Individual Talent," and it is this narrow conception of modernism from which Millay is often excluded. Of course, this is only one articulation of the many and varied modernisms that contemporary scholars recognize. Kaiser reminds us, "That her failure to accept the growing dominance of modernist ideology led to her exile from the canon...tells us more about cultural shifts than it does about the value of her poetry" (40). As Millay "revels in the possibilities of the present and assumes the sentimental privilege of personality in order to more fully participate in modernity" (Kaiser 34), she looks to "the public and to local politics to enact immediate change" (39).

Millay's work as a political activist was often ignored or disparaged by critics in her own time and went largely unstudied until the 1990s. ${ }^{3}$ Millay engaged in political activities, such as, marching for Sacco and Vanzetti in 1927 and raising funds for the publication of anarchist Emma Goldman's autobiography. Horrified by the destructive rise of Hitler's Third Reich, 
Millay began publishing propaganda verse in 1940. These pieces appear in a collection entitled Make Bright the Arrows. She also produced work for the Writer's War Board, including a ballad narrating the story of the Czech village of Lidice, which was destroyed by the Nazis. Millay's “The Murder of Lidice" was performed on the radio in 1942. For the most part her political writing was not well received by her friends and critics at the time. ${ }^{4}$ Millay's flurry of political writing in the early 1940s also took a toll on her health, and in 1944 she suffered a nervous breakdown and was unable to write for a period of time.

Earlier in her career and prior to Hitler's rise to power, Millay was a fervent pacifist. She protested the deaths occurring overseas during World War I in a biting one-act verse drama called Aria da Capo, first performed in 1919. Millay was proud of this political satire, considering it "a peach, - one of the best things I've ever done” (qtd. in Milford 178). The play's structure is unusual in that it features two stories in the same theatrical frame, one a colorful harlequinade with dark undertones and the other a simple pastoral turned horrendously violent. In the harleqinade, the clowns' purpose is twofold: to enact the sumptuous life of the upper classes and their callous indifference to the horrors of war and to highlight implicit violence in male/female relations. The shepherds in the pastoral act out a microcosm of war as it has played out throughout history. Most explorations of Aria Da Capo focus on its political implications and its function as a pacifist parable. ${ }^{5}$ However, I am interested in the metatheatrical and potentially transformative moments of resistance in Aria da Capo when living bodies attempt to interrupt traditional theatrical mimesis. Both sets of characters seem aware of their own theatricality; while they know they must follow the script, at times they express their unwillingness to do so. The diegetic impulse in Aria da Capo provides a narrative that structures the play but also questions and revises that narrative by calling attention to how we make sense of the repetitive 
cycles of violence and war throughout history. The characters' attempts to resist the script parallel Millay's own act of resistance, her metatheatrical citation of traditional dramatic forms.

\section{Theatrical Millay}

While she is more commonly recognized as a poet, Millay wrote a number of popular plays and verse dramas and also acted in productions at Vassar, where she attended college, and with the Provincetown Players of Greenwich Village. In her senior year at Vassar, Millay both wrote and starred in The Princess Marries the Page, a free-verse drama with a fairy-tale plot which was later revived by the Provincetown Players. Her Two Slatterns and a King was also first performed at Vassar and later produced by Provincetown. Millay became involved with the Provincetown Players in 1917 through her association with Floyd Dell. She acted in numerous productions and served on the executive committee. Aria da Capo was Millay's final play produced by Provincetown. Notably, Millay herself directed this first production of the play, and her sister Norma played the female lead. Alexander Woollcott, drama critic for The New York Times gushed, "You should see this bitterly ironic little fantasy by Edna St. Vincent Millay...this is the most beautiful and most interesting play in the English language now to be seen in New York" (qtd. in Milford 178). The play turned out to be wildly popular; it ran for two weeks and every performance was sold out.

The play features only five characters, Pierrot and Columbine, clowns who represent the decadence of the upper classes, the poor shepherds Corydon and Thyrsis, and Cothurnus, the Masque of Tragedy. The play begins with Pierrot and Columbine's absurd dinner conversation that focuses on love and cuisine, representing the frivolity and extravagance of the leisure classes. Cothurnus intrudes and beckons the shepherds to come on stage. As they act their scene, 
the shepherds' innocent songs and games gradually become cruel and violent, their actions reflecting a microcosm of society. They enact private property and wealth, finally killing each other out of hate and suspicion. Their bodies are left under Pierrot and Columbine's banquet table as they are called by Cothurnus to return and begin the play again. Cothurnus commands, "Pull down the tablecloth on the other side, and hide them from the house, and play the farce. The audience will forget" (Millay 281). Thus, Pierrot and Columbine begin their banquet again, disregarding the scene of carnage that lies just under their table.

Appended to the script, Millay provides surprisingly extensive and specific notes and stage directions in what she calls an "informal prompt book." In her author's note preceding the prompt book, Millay gives her rationale for this genre. She explains that she included very few "explanatory parenthesis" in her original version of the play for the Provincetown Players, so as not to disrupt the flow of dialogue. "So great is my vexation always, when reading a play," she says, "to find its progress constantly being halted and its structure loosened by elaborate explanatory parentheses" (12). It is an aesthetic choice on the part of the author, then, not to include many stage directions in the text. Interestingly, Millay seems to view this play firstly as written text and secondarily as performance:

Since, however, Aria da Capo was written not only to be read but also to be acted, and being conscious that the exclusion of the usual directions, while clarifying the play to the reader, may make it bare of suggestions and baffling to the producer, I am adding here some remarks which have been found of value in preparing it for presentation on the stage. (12) 
Millay explains that certain "little theatres" who were interested in producing the play wrote her asking for additional production instructions. The prompt book is cobbled together from answers to specific queries she received regarding the play. She adds the following caveat: "It will be found incomplete and uneven, in some instances unnecessarily detailed, in others not sufficiently so; all of which is due to the fact that it was put together loosely, from answers to chance questions, rather than logically, as an entity in itself" (12). However, the prompt book is dense, detailed, and quite lengthy for such a brief play, over a dozen pages. The level of detail becomes almost tedious at times. Given her background in the theater, it is unsurprising that Millay would take into account these very practical considerations. Here we see the marriage of artist and practitioner. She is unwilling to mar her masterpiece by including disruptive stage directions. However, when prompted she seems more than willing to step into the role of director and offer very specific instructions on staging, costuming, characterization, and properties.

Like Barnes and Bennett, Millay utilizes non-monumental, popular genres to express progressive ideas and comment on social inequity and violence. The structure of Aria da Capo combines two traditional dramatic forms, the commedia dell'arte and Greek tragedy. Her use of the commedia dell'arte is a brilliant move given commedia's focus on the tragic as well as the comic and its use of stock characters who function as ciphers of society. Martin Green and John Swan note that the following characterizes the commedia sensibility in an artist: "Strategically speaking, the low forms were accommodated to high ambitions above all by means of parody, irony, and fragmentation. These three artistic strategies obviously have a lot in common. You parody something just by fracturing it, and you ironize just by juxtaposing fragments" (16). As a commedic playwright Millay utilized these strategies, combining fragments of different genres and incorporating irony in her unique style of tragic humor. 
In Aria da Capo Millay deftly rewrites violence as theater, emphasizing performance as social pedagogy. One way she accomplishes this is by focusing on the metatheatrical. Notably, the manner in which the play is performed constantly calls attention to performance itself; the audience is repeatedly reminded that they are viewing a performance on a stage. Although Aria da Capo was written more than a decade before Bertolt Brecht's development of epic theater, it anticipates Brechtian technique in its meta-theatricality as well as its focus on history. Brecht's drama calls for a narrator, for the actors to consciously "re-present" rather than to become the characters, and for the audience to become active spectators. According to Brecht, in drama "the event has taken place; what you see now is a repeat" (397). This sense of repetition is one of the defining characteristics of Aria da Capo. The events the audience sees are clearly self-conscious representations of events that have happened in the past and will happen again in the future.

Aria da Capo's performativity stems from its representation of history, violence, and repetition. In her essay on performative writing, Della Pollock explains that performative writing is "citational," meaning it "quotes a world that is always already performative- that is composed in and as repetition and reiteration" (92). The sense of history that Millay creates in the play is comprised of discourses and repetitive practices. ${ }^{6}$ The repetition she emphasizes is not part of a monolithic, linear narrative; rather, it gestures toward a cyclical yet discontinuous pattern of human behavior. As Pollock notes, "the story of living bodies always already contesting, at both macro- and micro-political levels, the social texts to which they are otherwise indentured" (Pollock 91). As the characters in Aria da Capo descend into violence, the play posits a political view of history not as text, but as "living bodies." The characters serve as symbolic manifestations of cycles of destruction and violence in human history. They appear to have little to no agency; they must play the play according to the script. However, there are moments of 
resistance when the characters attempt to break out of their assigned roles and call attention to their own theatricality.

Theater has rhetorical and subversive potential insofar as it invites a dynamic interplay between writer and reader, playwright and audience. Ansgar Nunning and Roy Sommer distinguish mimetic narrativity, which focuses on "the projection of a sequence of events" and "aesthetic illusion" from diegetic narrativity, which "foregrounds the act of narration" (339). Nunning and Sommer identify diegetic narrative elements as they appear in drama, including "narrating characters," "verbal summaries of offstage action," "stage directions," and "all types of metanarrative comment" (341). When these elements appear in Aria da Capo, they introduce a different mode of storytelling in drama that narrates rather than demonstrates. When at certain times a character serves as narrator or directs the action of the play, or when characters attempt to "hold" the play because they know the outcome, these actions gesture toward the possibility of transformation. As J. Hillis Miller has noted, "performative" is "the power of a narrative to make something happen as opposed to its power to give, or appear to give, knowledge" (78). Insofar as performance narrates rituals and functions as a microcosm of society, it has the ability to teach and possibly even to enact a better future. In Aria da Capo, Millay highlights the didactic challenges theatrical representation can pose.

\section{Millay and the Commedia}

Because it draws upon a number of dramatic forms, Aria da Capo is difficult to categorize in terms of genre. In one of the only existing studies of Aria da Capo as commedia, McKee calls attention to this conglomeration of popular dramatic forms in the play: 
Millay did not choose to write theater-poetry based on folk myth or ritual, as so many playwrights did in the twenties; neither did she write a thesis play on social reform; nor did she write an intellectual farce, in which the point is in the game of ideas. What she did write had a dash of the first, a pinch of the second, and a generous sprinkling of the third, with the commedia dell'arte form as one of the main ingredients. (165)

In Aria da Capo Millay presents her audience with two scenes drawn from common dramatic sources, the harlequinade and the pastoral, with cadences and tones that are different but complementary. Ross Wetzsteon appropriately summarizes the play as a "counterpoint between brittle harlequinade and embittered pastoral disenchantment" (264). Indeed, the musical term "counterpoint" refers two or more voices in harmony that are independent in rhythm and contour. The commedia traditionally incorporated song and dance, ${ }^{7}$ and Millay appropriately draws upon a musical form in her title and structure. The play features two distinct scenes and the first scene starts to repeat at the end, a characteristic of the Baroque da capo opera aria, a ternary form in which the first and third movements are orchestrated to be nearly identical. The second movement in a da capo aria shifts in mood and tone from the first movement. Indeed, in Millay's Aria the first and second scenes are clearly parts of the same orchestration, although the tone differs.

Millay draws upon popular dramatic genres and transforms them into vessels of her modern aesthetic. Atkins notes that in Aria da Capo Millay utilizes several writing techniques often considered to have originated in T. S. Eliot's "The Wasteland," which was published the following year, including "a complex poetry which telescopes time by presenting several historical time periods simultaneously, and which, in the second place, uses a new method of 
writing tragedy, presenting it with deliberate reticence, under a surface of bitter jest" (78). This disruption of linear history and "tragic humor" are hallmarks of Millay's dramatic style in Aria da Capo, and they lend a sophisticated and modern sensibility to her playwriting.

Featuring masked character types, the traditional sixteenth-century Italian commedia favored largely improvised action but drew upon a basic plot structure or scenario. Originally associated with carnevale, circus, masque, and farce, the commedia was traditionally a form of "low" art that was adapted for higher forms, as it later came to be associated with classical and Shakespearean drama and was adapted for activist and experimental art during the modernist period. Indeed, the commedia was used by many modernist writers and artists, often in experimental drama. ${ }^{8}$ Green distinguishes commedia from other types of political or artistic radicalism, explaining that commedia "may have fostered culturally significant entertainment enterprises and inspired... genuine aesthetic response. But there remains something nonserious in its intentions, something defiantly frivolous or sullenly crude, which distinguishes it from other forms of protest" (xvi). It is exactly this frivolity and crudeness that Millay wishes to express to the audience in this play. As a form of protest, commedia combines the comic and the tragic in order to hold up a mirror in which society sees itself reflected.

Aria da Capo begins with the harlequinade, drawn from the larger tradition of the commedia and featuring the clowns Pierrot and Columbine. These two characters, traditionally a valet and serving maid, have a long and complex history dating from late seventeenth-century Italy. A somewhat pliable stock character, Pierrot shifted to reflect the values and ideals of each new generation. In the postmodern era Pierrot has often appeared in art and pop culture as a sad clown with a black tear on his cheek. On the cover of her recent single "Applause," Lady Gaga appears wearing the traditional black skullcap of Pierrot, her face awash in colorful and 
artistically smeared clown makeup. ${ }^{9}$ However Pierrot had his beginning in commedia as a naïve buffoon caught in a love triangle with Columbine and Harlequin. ${ }^{10}$ At the hands of the late nineteenth-century symbolists Pierrot became a narcissistic dreamer, and in the modernist commedia he came to represent a human type exemplified by artists and writers such as Jules Laforgue and T. S. Eliot. Green and Swan describe this "characteristic type behind commedia art" as "socially elusive, psychologically eccentric, intellectually oblique, with abysses of metaphysical melancholy within, and lifelines of frail humor, hypersensitive and hypersubtle" (26). In the first two decades of the twentieth century Pierrot the clown, the commedia buffoon, completes his transformation into a cypher of modern society, embodying the existential vision of the artist, the gravitas of the performer, and the ennui of the modern man. This is the Pierrot that feasts and frets in Millay's Aria da Capo.

Columbine, the serving maid and love interest of both Pierrot and Harlequin in the traditional commedia, is disturbingly superficial and vacuous in Aria da Capo. Arrayed in pink tarleton skirts and sporting a bobbed hairstyle reminiscent of a flapper, Columbine is described by Millay as "pretty and charming, but stupid," believing that "men prefer women to be useless and extravagant" (“Author's Note" 15). Columbine's role in the play seems to be to serve as a muse or support to Pierrot. As Millay explains, "She never knows what Pierrot is talking about, and is so accustomed to him that she no longer pretends to understand him; but she is very proud of him, and when he speaks she listens with trustful admiration" (15). Interestingly, however, almost as an afterthought Millay adds that "if left to herself she would be a domestic and capable person" (15). This is a telling comment, especially given that Millay herself was sometimes described as a Columbine-character with a seductive, muse-like quality. ${ }^{11}$ It seems that for Millay, Columbine represents the type of modern woman who concerns herself with style and 
superficial qualities, choosing to appear vapid and mindless because she thinks this is what is expected of her by her male companions. Millay herself did cultivate a charming persona, but she also highly valued her own intellect and reveled in her professional success. The Columbine character calls attention to the worst qualities of the modern woman, the privileging of style over substance.

When they play begins Pierrot and Columbine are seated at either end of a large banquet table arrayed with macaroons, artichokes, peacock's livers, caviar, and persimmons. Their chairs are festooned with colorful paper ribbons which will be used in the next scene. Their asinine topics of dinner conversation jump quickly from love and cuisine to contemporary artistic and political movements. In the opening lines of the play Columbine pines for a macaroon, to which Pierrot replies that he will kiss her if it's Tuesday. The conversation continues in this vein, with no meaningful emotional or intellectual connection between the characters. They talk around and over each other, Pierrot lapsing into nonsensical philosophical musings, while a daft Columbine tries and fails to follow his convoluted thought processes and wonders idly if he is mocking her:

COLUMBINE: Pierrot, do you know, Sometimes I think you're making fun of me.

PIERROT: My love, by yon black moon, you wrong us both.

COLUMBINE: There is no sign of a moon, Pierrot.

PIERROT: Of course not.

There never was. "Moon's" just a word to swear by. (265)

In their absurd frivolity and excess the clowns may amuse, yet they also come across as disturbingly shallow and flat. As McKee notes, "They lack good will, warmth, love of 
fellowman, and easy emotional flow; instead, they have a certain charming and disarming Charlie Chaplin helplessness" (166). The clowns serve as the traditional commedia buffoons, yet their superficiality is more disconcerting because it is part of their modern sensibility.

Beneath the seemingly innocuous chatter between these characters there are undercurrents of boredom, discontent, and even abuse. In the prompt book, Millay devotes several lengthy paragraphs to describing Pierrot's character, his boredom with Columbine, his listlessness, and his belief that "all beauty and romance are fled from the world" (15). Unlike the traditional naive buffoon, Millay's Pierrot "sees clearly into existing evils and is rendered gaily cynical by them; he is both too indolent and too indifferent to do anything about it" (15). Pierrot seems to be moved by forces beyond his control, the undeniable force of modernity, and this contributes to the malaise and melancholy that is ever-present beneath the surface of his forced cheerfulness. There are several moments in the scene when his discontent breaks through and becomes obvious. When Columbine upbraids him for his drinking Pierrot replies, "I am always wanting / A little more than what I have, -or else / A little less. There's something wrong" (262). Later, Columbine says she is growing tired of caviar and peacock's livers. She asks, “Isn't there something else / That people eat?—some humble vegetable, / That grows in the ground?" (265). Pierrot replies that he is tired as well, of "gowns that have the waistline / About the waist, and the hem around the bottom- / And women with their breasts in front of them!- / Zut and ehe! Where does one go from here!" (265). While Columbine yearns for simpler fare, a return to the organic and earthy, Pierrot is sick of convention and weary of humanity. Interestingly, he couches this existential world-weariness in terms associated with the female form. He is not only tired of conventional dress styles, but also of women "with their breasts in front of them." There is an authentic human melancholy here that goes beyond fashionable modern discontent. Beneath 
the external frippery of style and convention, humanity seems unchangeable, destined to participate in the same wearying cycles of destruction and violence again and again.

As the scene continues there is obvious tension between Pierrot and Columbine. Millay notes that Pierrot often speaks to Columbine with "mock saccharine tenderness" and that "although he speaks very gaily, his malice must be apparent almost even to her" (15). Pierrot constantly undermines, mocks, and dominates Columbine, often thinly veiling his insults with word play. At times he abuses her more directly. At one point he asks Columbine if she would like to be an actress and she replies that she cannot act, to which he rejoins: "Can't act! Can't act! La, listen to the woman! / What's that to do with the price of furs?-You're blonde, / Are you not?-you have no education, have you? — / Can't act! You underrate yourself, my dear!" (264). Pierrot assumes the position of power throughout the scene, in this instance insulting Columbine by referencing her feminine stupidity and inclination for artifice. Here Millay also includes a sardonic critique of actresses, perhaps a self-conscious indictment of Greenwich Village culture.

The audience could not have failed to recognize this harlequinade as a critique of bohemian culture, as the clowns make a mockery of the decadence of the upper classes and lampoon various social and artistic movements of the time. During their repartee, Pierrot variably declares himself a socialist, a pianist, an acting manager, a theater critic, and notably a Cubist painter: “...I am become / A painter, suddenly, —and you impress me— / Ah, yes!—six orange bull's-eyes, four green pin-wheels, / And one magenta jelly-roll, — the title / As follows: Woman Taking in Cheese from Fire-Escape" (263). This is one of several examples in which Millay uses Pierrot to skewer Greenwich Villagers for their fickleness in participating in the latest trends in popular artistic and social movements. Pierrot, a character beloved of the Cubists 
and Picasso in particular, would have been very familiar to Millay’s audience. Millay did attend the Armory Show of 1913, which displayed the work of Van Gogh, Duchamp, Matisse, and Picasso, among others. Cubist-inspired paintings such as Duchamp’s Nude Descending a Staircase and Matisse's Blue Nude caused quite a sensation, and many American artists were shocked and even threatened by this revolutionary abstract style. Millay herself was unimpressed by the exhibition, describing the Cubist works in a letter as nothing more than "piles of shingles" (qtd. in Black 24). Still, Millay could not deny the influence of this European art form and its profound effect on modernism. Millay's Pierrot takes on quite a complex role; he is a figure resurrected from the traditional commedia who is now associated with a polarizing modern artistic movement. A tragi-comic figure himself, in Aria da Capo he mocks decadence and modern capriciousness.

Historically, because the commedia was improvised it often did satirize current figures or events in this manner. In her exploration of Aria da Capo as produced within the context of the Provincetown Players, Brenda Murphy posits the play as a self-conscious critique of the aesthetics of the group itself, noting that "Millay shapes Pierrot and Columbine, traditional lovers from the harlequinade, into representatives of the modern version of carpe diem that characterized the typical Greenwich Village bohemian" (144). The Players were not blind to their own position of privilege and certainly not above satirizing themselves in their work. Millay gives the harlequinade a modernist twist, transforming the characters into ciphers of modern society.

However, Millay's choice to use the archetypal commedia clowns in the play obviously moves beyond Greenwich Village to the larger political and social concerns of American society as well. In his exploration of food and modern American culture in Aria da Capo Michael Fahy 
takes the significance of this scene beyond a critique of local culture, arguing that the presentation of food in the harlequinade represents the "dangerous excesses of American culture more broadly — a culture that often valued escapism over social and political engagement and encouraged audiences to forget history rather than to contemplate its consequences" (4). In Aria da Capo Millay warns that "the escapist pleasures of entertainment and modernist art could be socially irresponsible" (Fahy 4). As Pierrot and Columbine feast and prattle, they seem to turn a blind eye to the realities of the outside world. This is especially obvious as their scene is intruded upon by the shepherds of Greek tragedy, providing a marked contrast to the frivolity of the harlequinade.

\section{A Tragedy within a Comedy}

In the middle of the play Millay disrupts audience expectations and generic conventions by switching from comic harlequinade to Greek tragedy. Pierrot and Columbine's dinner comes to a premature and abrupt end when Cothurnus, the Masque of Tragedy, intrudes on the scene. Pierrot, shocked at his rudeness, upbraids him and tells him to get off the stage. However, Cothurnus insists that he is tired of waiting and the tragedy must commence. The clowns eventually exit and Cothurnus calls the shepherds Thyrsis and Corydon to begin their scene. When they reply that they are in their dressing room and the scene is not to happen until later, Cothurnus insists that they play it now. The sorrowful readiness of the shepherds as they prepare suggests that they know the outcome of the scene, the dissolution of friendship and innocence and the eruption of suspicion and violence. Millay provides a detailed characterization of the shepherds; their simplicity and guilelessness places them in direct contrast with the contrived manner and frivolity of the clowns: 
These two characters are young, very simple, and childlike; they are acted upon by the force that sits on the back of the stage behind them. More and more as their quarrel advances they begin to see that something is wrong, but they have no idea what to do about it, and they scarcely realize what is happening, the quarrel grows so from little things into big things. ("Author's Note” 16)

The shepherds are passive, "acted upon by the force that sits on the back of the stage behind them," (16) which is, of course, Cothurnus, the Masque of Tragedy. They seemingly have no control over their own actions, and when violence erupts they are objects of pity. Yet Millay insists that they must be "strong and vivid in every way," (16) right down to the colors of their cloaks, which are bright red and blue. Millay is very keen on the point that there must be no other red or blue used in the play, presumably to stress the purity and vigor of these simple characters. They are dressed simply in tunics and sandals, contrasting the sumptuous pastel costumes of Pierrot and Columbine.

The shepherd characters are drawn from Virgil's seventh Eclogue, in which Corydon wins a singing contest with Thyrsis as they watch over their sheep. What appears as a friendly poetic rivalry in the pastoral Eclogues, however, descends into something much more violent and sinister in Aria da Capo. The shepherds' scene begins innocently as they recline against rocks and engage in idle conversation as their sheep graze. Corydon proposes that they sing a song about a lamb, but Thyrsis, at Cothurnus's prompting, suggests that they play a game instead. As the scene proceeds, the shepherds are caught up in a game of their own making, powerless to stop the gathering momentum of history, or perhaps Millay suggests, human nature. First, they construct a wall out of the paper ribbons on Pierrot and Columbine's chairs to separate their lands and they divide their flock, representing nationalism. Corydon notices that the stream is on 
Thyrsis's side of the wall, which means that he cannot water his sheep. Corydon reaches over the wall to embrace Thyrsis, but Thyrsis is afraid he is being tricked, to which Corydon, as the horror of the situation dawns on him, exclaims, "But one of us has to take a risk, or else, / Why, don't you see? - the game goes on forever!... / It's terrible, when you stop to think of it.../ Oh, Thyrsis, now for the first time I feel / This wall is actually a wall, a thing / Come up between us, shutting you away / From me...I do not know you anymore!" (272-273). The shepherds are saddened and alarmed by their own growing suspicion of each other and several times they express their desire to stop the game, but it is clear they cannot.

The game of war moves on with its own momentum, and what began as an innocent game soon leads to violence and death. Corydon accumulates wealth in the form of colored stones, which leads to individualism and greed. He abandons his sheep and fancies himself a merchant. Soon he grows thirsty, however, and Thyrsis develops a plan to place a poisonous root in his drinking water. Meanwhile, Corydon strings his colored stones onto a necklace which he plans to use to strangle Thyrsis. In the tragic final moments of the scene Corydon, in his death throes, strides through the wall to find Thyrsis's body, only to discover that there was no wall at all, only thin bands of tissue paper. He then falls over the body of his friend and dies. Millay makes it clear throughout the scene that these characters have no agency or control over the outcome. When the shepherds seem to falter as the scene turns darker, Cothurnus prompts them with their lines, forcing them to play the fated scene through. This sequence of events has occurred many times and will continue to occur.

The dramatic tension in this scene stems from the struggle between personal will or desire and the necessity of one's destiny, a trope that appears frequently in Greek tragedy. In Aristotle's Poetics, tragedy is defined as the imitation of an action according to the law of 
probability or necessity. In traditional Greek tragedy the downfall of the hero is often brought about by fate or the will of the gods. In Aria da Capo, Millay draws upon a combination of Greek pastoral and tragic traditions, making use of Virgil's innocent shepherds and transforming them into agents of their own demise. Cothurnus's character personifies necessity, urging the shepherds on despite their own desires. Raymond Williams traces the trajectory and development of tragedy from ancient Greece through the modern day, explaining how the basis of tragic action moved from fate and the will of the gods in ancient times, to notions of poetic justice and morality in the eighteenth century, to modern tragedy, which rejects notions of an unchanging or universal human nature and focuses on changeable conventions and institutions. The shepherds function simultaneously as ancient literary figures representing the timeless tendencies of human nature and fallen soldiers of the First World War.

Millay's audience would undoubtedly have interpreted the shepherds' scene in Aria da Capo as an indictment of the violence of World War I. The Treaty of Versailles was signed in June 1919, and Aria da Capo opened in December of the same year. In this pastoral scene the audience observes the swift movement from nationalism and individualism, to greed and envy, and finally to death and violence. Despite the brevity of the scene, there is nothing simple about this escalation of events. Americans at this time were still reeling from the toll of war and its effects on human life and culture. This tragic scene not only directly follows but physically intrudes upon the clowns' sumptuous dinner, even utilizing the same props. The message is clear: Greenwich Villagers and Americans as a whole cannot ignore the scenes of violence that have been enacted on a world stage, nor can they distance themselves from this violence by reducing it to abstraction. Williams describes a dimension of cultural tragedy as "an action of war and social revolution on so great a scale that it is continually and understandably reduced to 
the abstractions of political history, yet an action that cannot finally be held at this level and distance, by those who have known it as the history of real men and women, or by those who know, as a quite personal fact, that the action is not yet ended" (13). In the lifeless bodies of the shepherds on stage, political abstraction becomes tragic reality. For some in the audience, this heartrending reality hit quite close to home. In his review of Aria da Capo, the New York Times's Alexander Woollcott asserted, "No mother from a gold-starred home, who saw the war come and go like a grotesque comet and who now hears the rattlepated merriment of her neighbors all the more distinctly because of the blank silence in her own impoverished home-surely no such mother will quite miss the point of "Aria da Capo"' (40-41). The tragedy Millay represents in Aria da Capo is specific and localized, a tragedy both national and personal.

Some critics have read Aria da Capo more narrowly as a socialist critique fueled by the character of Cothurnus, who serves as the voice of government propaganda. The support of the American public for the war was tepid from the start, with relatively few men willingly enlisting. ${ }^{12}$ Government propaganda supporting the war effort was spread by George Creel and the newly formed Committee on Public Information. Many dissenting voices were silenced; Max Eastman's socialist publication The Masses was banned, and members of the Socialist party and the IWW were jailed. Michael Cotsell argues for Aria as a socialist critique of the war, and his strongest argument is the character of Cothurnus as representative of "the forces that determined the war" and the "personification of militarist/industrial capitalism" (127). Cotsell notes that Cothurnus is solely responsible for controlling the action of the play, acting as puppet master and even hypnotist to the other characters in his modern role as the overbearing force of history and capitalism to which they must submit (127). Fahy takes his analysis further, viewing the 
character of Cothurnus not only as representing the determining forces of the war but also as an embodiment of Millay's own anxiety about her role as playwright:

A tension emerges between Millay's explicit critique of wartime propaganda and the implicit meta-theatrical anxiety about the act of playwriting that provides the vehicle for that critique. At some level, the Cothurnus character is both an explicit critique of manipulative politics and an implicit working out of the tension Millay felt over doing something similar. Highly political art has the power to manipulate behaviors and beliefs, and the line between this work and propaganda, between a game and real violence, can be thin indeed. (12)

Surely Millay did feel the irony of creating a potentially propagandist play in this environment of political strife and violence. The character of Cothurnus, then, not only represents localized powers at large but, more importantly, questions the role of political art and the authority of the playwright. These questions of authority are symbolized by the presence of the prompt book; Cothurnus carries his under his arm on stage and Millay's was distributed with the play script. Rather than serving as authoritative guides to the play, the prompt books serve as examples of one interpretive medium, one way of presenting the performance which may well be changed or disrupted.

While political readings of the play are well supported, I argue that it is more useful to view Cothurnus not as undisputed dictator or overbearing force of history, but as a figure whose authority and timing can and must be challenged. It seems reductive to view the play as a simple socialist critique when Millay adds so many levels of irony. Indeed, it should be noted that socialism is one of the movements Pierrot mocks in the previous scene: "I am become a socialist. 
I love / Humanity; but I hate people" (263). Lest the play spread an overtly propagandist onesided message, Millay adds complexity to the plot by giving the other characters in the play space to pause, to question, even to whine. There are moments in the play when the other characters oppose Cothurnus' authority and attempt to assert their own agency, and in this tension potential progress lies.

As a figure of limited authority, Cothurnus is the most complex and ambiguous character in the play. Directing and mediating between the two storylines, Cothurnus is both character and dramaturg; he acts in the play while also shaping and interpreting the story. In her author's note, Millay stresses the significance of Cothurnus' voice and tone: "The voice of Cothurnus is one of the most important things in the acting play. He should have a voice deeper than the voice used by any of the other persons, should speak weightily and with great dignity, but almost without intonation, and quite without feeling, as if he had said the same words many times before" (15). It is interesting to explore Millay's construction of this character in terms of how the Masque of Tragedy functions with regard to his traditional role in Greek tragedy and the genre's connections to the commedia. In her exploration of the origins of commedia dell'arte in Italy, Annette Lust notes that "the commedia's growth was because of a renewed interest in ancient classical plays and because of the satiric tendency of the period" (38). Millay notes that Cothurnus is to wear a mask or have his face painted to represent one, so as not to affect the resounding quality of his voice (15). The mask links Cothurnus to ancient Greek tragedy and also plays into the commedia's historical use of masked character types. Cothurnus serves as mediator between comedy and tragedy.

Notably, Cothurnus is not the only character who has the power to control the action of the play; as Millay notes, the clowns and the shepherds also engage at various points in "holding 
the play" (23). Thus, all of the characters are both agents and victims, capable of limited manipulation of the plot but unable in the end to resist the violent outcome. The greatest moments of tension between Cothurnus and the other characters occur during these metatheatrical moments, when the characters disagree with Cothurnus about how to proceed. When Cothurnus enters and attempts to switch the scene from comedy to tragedy both the clowns and the shepherds argue that it is too soon. When he enters Pierrot tells him to "get off the stage": "You don't belong on here. Wait for your own scene! / Whadda you think this is,-a dress-rehearsal?" (266). Cothurnus admits that the tragedy is planned for later, but he is insistent that it be played now. He ushers the clowns off stage and he calls to the shepherds, who reply that they are in their dressing room and are not prepared to go on:

CORYDON: Sir, we are counting on this little hour.

We said, "Here is an hour, -in which to think

A mighty thought, and sing a trifling song, And look at nothing."-And behold! The hour, Even as we spoke, was over, and the act begun, Under our feet!

THYRSIS: Sir, we are not in the fancy

To play the play. We had thought to play it later.

COTHURNUS: Besides, this is the setting for a farce.

Our scene requires a wall; we cannot build

A wall of tissue-paper!

THYRSIS: We cannot act

A tragedy with comic properties! 
COTHURNUS: Try it and see. I think you'll find you can.

One wall is like another. And regarding

The matter of your insufficient mood,

The important thing is that you speak the lines,

And make the gestures. Wherefore I shall remain

Throughout, and hold the prompt-book. Are you ready?

CORYDON-THRYSIS: [Sorrowfully.] Sir, we are always ready.

COTHURNUS: Play the play! (268)

The shepherds are not ready to play the scene, and they voice their opposition to Cothurnus citing several excuses. They wish to pleasantly while away the final hour before their doom musing and singing. Because the time has unexpectedly come upon them, they are not in the sufficiently grave frame of mind the scene requires. Although they seem bewildered by later events, their reluctance suggests they are aware of the final outcome of their scene. They also argue that the set is not right; the props for the clowns' sumptuous dinner will not do for their tragic scene. As Cothurnus well knows, the props are unimportant; a wall can just as easily be made from tissue paper ribbons as brick and mortar. This dialogue calls attention to the fact that all comedy and tragedy is performance; the shepherds need not feel anything, only speak and move. These human actions represent the force of history, exemplified by Cothurnus and his prompt book.

If Cothurnus represents a dehumanized, linear and monolithic version of history, then the shepherds question this model. Eventually they "sorrowfully" succumb, but not before they have disrupted the action of the play by voicing their concerns. These metatheatrical moments that disrupt the linear action of the play are not separate interludes; they are woven into the fabric of 
the drama. When the shepherds "forget" their lines or when Cothurnus fails to keep the clowns and shepherds in their respective separate scenes Millay is disrupting the historical narrative, questioning commonly held beliefs and repetitive practices. The shepherds forget their lines at crucial moments, particularly when the scene begins to turn darker, and Cothurnus supplies the line from his prompt book. The timing suggests that the shepherds either consciously or subconsciously desire to stall or change the direction of the scene. Also, although Cothurnus has ordered them to exit, the sound of the clowns' voices off-stage interrupt the action of the tragedy three times. Columbine even enters the scene at one point to retrieve her hat, and Thyrsis tells her to take it and go, his eyes never leaving Corydon. Columbine responds saucily, "Take it and go indeed. Is it my hat, / Or isn't it? Is this my scene, or not? / Take it and go! Really, you know, you two / Are awfully funny!” (273) Throughout the play the characters constantly struggle for control. When Columbine asks whether it is her scene she echoes Cothurnus, who earlier in the play has claimed that he $i$ s the scene (267). Millay suggests that this story cannot be told by one character or from one point of view or according to the instructions in one prompt book. Rather, the play is characterized by a multitude of voices and a great deal of dramatic tension.

\section{Millay and Metatheater}

Interestingly, although Millay draws upon older forms and genres her use of irony and her dramatic style are decidedly modern. Many elements of Aria da Capo anticipate Bertholt Brecht's epic theater and absurdist metatheater. Millay's performative and representative focus on history and violence is notably Brechtian. As opposed to traditional dramatic theater which features a linear and unified plot and an illusion of reality, epic theater is episodic and characterized by critical realism. While history provides background in dramatic theater, it functions as the subject of epic theater. As in Brechtian drama, in Aria da Capo the actors are 
demonstrators and the characters are types. As Lust points out, one of Brecht's sources for epic theater was the commedia dell'arte, notable in his use of devices such as pantomime to disrupt the traditional narrative and plot structure (54-55). Most importantly, epic theater posits that humans are not unalterable but are agents of change. Brecht explains that with the advent of epic theater, "the spectator was no longer in any way allowed to submit to an experience uncritically (and without practical consequences) by means of simple empathy with the characters in a play" (393). The emotional connection between actor and audience is much more ambiguous and ambivalent than in traditional theater, where a character may be more easily relatable. Epic theater is instructive in that the audience is invited to analyze and criticize the actions of the actors.

The audience's response to epic theater is counterintuitive in some ways, and this leads to a certain amount of affective unease and ironic distance. According to Brecht, the epic theater's spectator says, 'I'd never have thought it—That's not the way-That's extraordinary, hardly believable - It's got to stop-The sufferings of this man appall me, because they are unnecessary — That's great art: nothing obvious in it - I laugh when they weep, I weep when they laugh" (393). This is a particularly accurate response to Aria da Capo. The emotional detachment and affective confusion are hallmarks of Millay's style of tragic humor. ${ }^{13}$ This description of epic theater also recalls Pollock's definition of citational writing, in which she cites Brecht's drama as a poignant example: "Echoing the quotational meta-drama of a Brecht play, citational writing tends toward what Fredric Jameson calls "pastiche" - or parody without the punch, parody worn smooth by repetition" (92-93). Of course, pastiche celebrates the work it imitates, while parody employs a sharper, mocking irony. In citational writing and often in metadrama the parody is softened by repetition, rendering it more reflective. The clowns in Aria da 
Capo are not used to mock or critique the commedia but to celebrate it as a vehicle for social critique.

In some ways Aria da Capo anticipates the advent of absurdist metatheater led by such prominent playwrights as Luigi Pirandello and Samuel Beckett. Two years after the debut of Aria da Capo in New York, Pirandello brought metatheater into the mainstream with his Six Characters in Search of an Author, which opened in Rome to mixed reviews. Certain playwrights such as Brecht and Beckett used metatheater and other experimental techniques that lent an "anti-theatrical" impulse to their drama. Martin Puchner explains the ways in which modernist anti-theatricalism emerged as a response to avant-garde theatricalism, which rose in the late nineteenth century and found its modernist form in movements such as Dadaism and Futurism. This avant-garde movement to revive live theater was focused on revaluing and celebrating theatricality as such, while mainstream modernists were troubled by the unmediated mimesis at work with live actors impersonating others as well as theater's associations with the public sphere ${ }^{14}$ It is important to note, however, that anti-theater does not negate or reject the idea of theater itself. Puchner explains, "The resistance registered in the prefix anti thus does not describe a place outside the horizon of the theater, but a variety of attitudes through which the theater is being kept at arm's length and, in the process of resistance, utterly transformed" (2). Puchner notes that although one tradition celebrates theatricalism and one resists it, both can come to similar conclusions in their respective critiques of actual theater (7). Both avant-garde theatricalism and modernist anti-theatricalism have at their center a desire to transform theater by disrupting traditional theatrical techniques.

I argue that Aria da Capo falls in between these traditions; it is a celebration of traditional theater and theatricality, but it includes anti-theatrical elements. The clowns revive the rich 
history of the commedia del'arte, representing the best of theatrical excess with their sumptuous costumes and witty banter. But as Millay's characters also disrupt unmediated mimesis and hold the play, there is an unmistakable undercurrent of anti-theatricalism at work. Although they do recognize their own theatricality, Millay's characters do not quite acknowledge themselves as characters, nor do they grasp all that entails, as Pirandello's do in Six Characters. However, they are able to recognize and attempt to resist the inevitable forces at play, represented by Cothurnus. Nor has Millay arrived at the moment of existential crisis that dominates Beckett's plays or even the underlying hopelessness of Pirandello's drama. Williams argues that Pirandello's “dramatic world is one of guilt and illusion: the guilt interlocking and complicated, in a series of false personal relationships; the illusion elaborate and persistent, as a way of avoiding or living with the guilt [...] Straight and truthful relationships have become impossible, and the only defense against suffering, the only source of innocence, is fantasy" (146). This attitude is glimpsed in the false merriment and barely disguised despair of the clowns, but in the characters of the shepherds Millay attempts to convey sincerity and authentic innocence. Still, the ending of Aria da Capo does suggest a sort of nihilism, as that innocence is shattered and the humanity of the shepherds is disregarded.

Although the ending of the play is immanently tragic, Millay does offer a possibility of redemption. The final scene includes a brilliant turn of the plot in which the clowns return and begin their dinner exactly as before with the bodies of the shepherds under their table. It is easy to focus on the clowns' callous insensitivity in this scene; however, Millay's prompt book instructions regarding their initial response to the bodies of the shepherds is crucial. When they notice the bodies Columbine screams in horror and then remarks, "How curious to strangle him like that, / With colored paper ribbons" (281). Pierrot replies, "Yes, and yet / I daresay he is just 
as dead" (281). Millay specifies that Pierrot is to speak this line not "flippantly or cynically, but slowly and with much philosophic concentration on the thought" ("Author's Note" 15). In fact, through the entirety of the scene Pierrot and Columbine are to "stand staring at the two bodies, without moving in any way, without even lifting their eyes" (15). Millay further notes, "For a moment the two characters seem almost to feel and be subdued by the tragedy that has taken place" (15). Pierrot then calls Cothurnus to drag the bodies out, saying the audience won't stand for dead bodies under the table. Cothurnus responds, "What makes you think so? - / Pull down the tablecloth / On the other side, and hide them from the house, / And play the farce. The audience will forget" (281). At this point Pierrot and Columbine finally raise their eyes to each other, Pierrot nods curtly, and they briskly resume the farce.

Like the shepherds, the clowns' human instinct and emotion seems to run counter to Cothurnus' instructions. After the deaths of the shepherds Cothurnus closes the prompt book matter of factly and claps his hands commanding, "Strike the scene!" (280). In contrast, when the clowns notice the bodies Columbine is horror-stricken, and even the ironist Pierrot is shocked and grave. When he speaks Millay makes it clear that this is not the glib and self-absorbed character of the earlier scene; indeed, Pierrot seems to grasp the full tragedy of these senseless deaths. When Columbine remarks on their use of paper ribbons she says the lines quite slowly and reflectively. Perhaps the clowns notice that a prop which was only a decoration in their scene has been transformed into a violent weapon in the hands of these simple characters. The frivolous lifestyle of the clowns does indeed cause harm, just as the lives of bohemian artists and people of the leisure classes had a direct bearing on the war. Pierrot also has more faith in the audience, wishing to spare them the grisly scene of the bodies, while Cothurnus insists that they won't notice. 
As a work of pastiche, Aria da Capo does not use the commedia mockingly, but as a vehicle to display this ironic repetition. The sense of repetition in Aria da Capo is citational because it posits that "repetition isn't all bad. Inevitably imperfect, it is the living sign that reproduction can never be total or absolute" (Pollock 92). Although events in history may be cyclical, each repetition brings crucial changes to the script. This notion of changeable repetition is most poignant in the final scene of the play. This is where Aria da Capo pulls back from the despair and nihilism that characterize much of the drama of Pirandello, Brecht, and Beckett. In the final meta-theatrical moments of the play, the clowns are reluctant to allow Cothurnus to sweep the bodies under the tablecloth without at least pausing to recognize what has happened. At Cothurnus' prompting, the clowns must make a conscious decision and force themselves to go on with the performance. Undoubtedly, repeating the comedy with the bodies under the table is crude and callous, but the audience sees that the clowns are emotionally affected by the violent scene. Therefore, this repeat is not the same. History may be comprised of cycles of war and violence, but despite Cothurnus' efforts, "living bodies" disrupt and alter these repetitive practices. When the characters pause, question, and stall, Millay opens the possibility that perhaps in the future the characters will be more successful at resisting the force of history. Pierrot and Columbine may pull down the tablecloth over the bodies of the shepherds and gaily repeat their mindless chatter, but for them as well as for the audience it takes on a much darker tone than it did at the beginning of the play.

One may argue that these small acts of resistance do not ultimately change the course of the play, nor indeed, the course of history. However, when performance demonstrates an openness to opposition or a change to a social script these gestures can translate to political and social realities outside the theater. In her exploration of the utopian performative, Jill Dolan 
describes the theater as a potentially dynamic space that gestures toward a "common future" which is more just and equitable: "Audiences are compelled to gather with others, to see people perform live, hoping, perhaps, for moments of transformation that might let them reconsider and change the world outside the theatre, from its macro to its micro arrangements" (455). One way these "moments of transformation" can come about is through storytelling, or a narrative mode in performance. For Dolan, storytelling has a dual function of "creating order and criticizing underlying assumptions" (477).

Within the context of the Provincetown Players, Millay was able to use her public influence to create an activist lyric and a political, expressive aesthetic. In her exploration of the influence of Millay on the work of other female political writers such as Muriel Rukeyser and Adrienne Rich, Artemis Michailidou emphasizes "the function of the female poet as a public, political artist" (8). Millay's Aria da Capo is undoubtedly a "deadly little play," but I argue that she leaves the audience with a sense of the potential power of humanity to overcome cycles of violence. Although it ultimately ends in death, Aria da Capo is more than, as Atkins calls it, "a bitterly hopeless analysis of the logic of all wars and of the irreversible machinery of tragic human history" (77). The hope that Millay offers lies in the power of theater to imagine not only a different sort of world, but also a different way of imagining history. 


\section{Notes}

${ }^{1}$ Although she was married for twenty-six years until her husband's death, Millay engaged in numerous love affairs throughout her life.

${ }^{2}$ See Walker, Masks Sentimental and Austere: Culture, Psyche and Persona in Modern Women Poets and Amy Clampitt, "Two Cheers for Prettiness." A Review of Edna St. Vincent Millay, Selected Poems.

${ }^{3}$ See Michailidou, "Edna Millay, Muriel Rukeyser, and Adrienne Rich" 8-9. Michailidou notes that even prominent Millay scholars such as Suzanne Clark disparaged or ignored her political work. However, more recent anthologies such as Sheldon's Her War Story: Twentieth Century Women Write about War (1999) and Barash's Approaches to Peace: A Reader in Peace Studies (2000) include selections of Millay's political poetry. Her political work is also explored in Milford's Savage Beauty: The Life of Edna St. Vincent Millay.

${ }^{4}$ See Milford, Savage Beauty 470-471 for responses to "The Murder of Lidice."

${ }^{5}$ In Republic of Dreams Wetzsteon notes, “Aria was part of a tradition of pacifist parables written in response to WWI but it was "one of the few to convey the tragic laughter that Santayana felt was the only appropriate response to the horrors of the new century" (264). ${ }^{6}$ Foucault's The Archaeology of Knowledge explores this rejection of straightforward, monolithic narratives of progress in favor of a view of history comprised of discourses and discontinuity.

${ }^{7}$ In From the Greek Mimes Lust explains the importance of song and dance to the history of the commedia: "During the sixteenth-century, when Italian street mimes were invited to perform at court, they introduced a type of comedy called dei maschere with song, dance, and masked characters" (38). 
${ }^{8}$ In The Theater of Trauma, Cotsell attests to the influence of the commedia on modernist authors, noting that Eugene O’Neill and Alfred Kreymborg also wrote plays in the commedia tradition (93).

${ }^{9}$ See http://gagajournal.blogspot.com/2013/08/gaga-pierrot-something-of-devoted-jester.html. This article is from the technological journal Gaga Stigmata: Critical Writings and Art about Lady Gaga. Roland Betancourt draws from art history and ekphrasis as he explores the symbolic significance of Gaga's album cover in the context of the traditional stock-character Pierrot. ${ }^{10}$ Sometimes Pierrot lost Columbine to Harlequin in these dramas. Other times he won her or even killed her.

${ }^{11}$ In The Triumph of Pierrot, Green and Swan describe Millay this manner.

${ }^{12}$ When the United States joined the war, a million men were needed. Only 73,000 enlisted, forcing the government to instate a draft.

${ }^{13}$ In Edna St. Vincent Millay and her Times this term is used by Atkins to describe a "fusion of farce and tragedy" (81).

${ }^{14}$ Puchner notes that these anti-theatrical arguments were led by Friedrich Nietzsche and Theodor Adorno. 


\section{Chapter 4}

Mina Loy's Identity Performance:

Autobiography and the Birth of the Poet in "Anglo-Mongrels and the Rose"

In her 1925 essay "Modern Poetry" Mina Loy observes: "The structure of all poetry is the movement that an active individuality makes in expressing itself. Poetic rhythm, of which we have all spoken so much, is the chart of a temperament" (157). Modern poetry and poetic form not only reflect the pacing and variety of modern life but also incorporate the rhythm and "spontaneous tempo" of the poet's day-to-day experience. "If at first it appears irksome to adjust pleasure to unaccustomed meters," Loy advises, "reflect in time that hexameters and alexandrines, before they became poetic laws, originated as the spontaneous structure of a poet's inspiration" (158). Thus, the formation and creation of each modern poet's verse stems from the same poetic impulse which originated traditional verse; the pace of modern life, however, shifts the tempo and speed. For all her emphasis on spontaneity, Loy's verse is considered by many to be carefully calculated and intellectual. Ezra Pound famously classified Loy's poetry as a prime example of logopoeia, or "the dance of the intellect among words" (25). ${ }^{1}$ In addition to using words for their lyrical, musical, or visual qualities Loy engages in ironic and satiric word play, subverting conventional expectations regarding word usage. Critics such as Debora Van Durme argue that Loy's verse goes beyond the "immaterial, cerebral, conceptual side of language," taking "an equally eager interest in language's materiality, its existence as a collection of visual signs on the page and, even more, as an aural phenomenon" (325). Given its complexity, Loy's poetry is notoriously difficult to categorize; it is intellectual yet material, measured yet spontaneous, distant yet personal. 
Although Loy was well-known among her modernist contemporaries as an avant-garde poet and artist, her work was largely ignored throughout much of the mid-twentieth century. Loy was recognized and praised by prominent writers of her time such as T. S. Eliot, Gertrude Stein, William Carlos Williams, and Ezra Pound, and she published in several avant-garde New York magazines such as Alfred Kreymborg's Others: An Anthology of the New Verse. However, by the 1930s her work had virtually disappeared, while the work of many of her contemporaries not only continued to gain critical attention, but also became instrumental in defining a developing modernist aesthetic. Several of Loy's recent biographers and critics propose reasons for this neglect, pointing to her eclecticism and her failure to pursue a traditional writing career. ${ }^{2}$ Indeed, Loy did not think of herself foremost as a poet, flamboyantly defying definition in her work as painter, designer, model, amateur actress, and playwright. According to Roger Conover, Loy was interested in becoming "the most original woman of her generation" (xiii), and she consciously constructed a unique identity by engaging simultaneously in different modes of creative selfexpression: "Throughout her career, Loy camouflaged demonstrative and theatrical first-persons behind inscrutable aliases. She ventriloquized. She dissembled. She canceled. Whether this was part of a conscious design to elude critical framing or an involuntary strategy for survival is difficult to say; in fact, there may be no distinction" (xiii). At various points in her life Loy was influenced by literary and artistic movements such as Dadaism, Surrealism, and Futurism, pulling from all of these in the construction of her kaleidoscopic artistic vision. Loy biographer Carolyn Burke suggests that Loy's aesthetic diversity is the reason she is resurrected in a postmodern context: "It may be that in her multiplicity, Mina speaks to us now, in the era of the postmodern, because she followed no one path and did not present a unified body of work" 
(viii). ${ }^{3}$ Loy's artistic and literary reflections of her own time speak to a contemporary audience, especially her explorations of gender and frank depictions of sexuality.

Much of Loy's poetry involves performances of femininity in resistance to dominant traditions and movements that defined women's roles within rigid strictures, repressed female creativity and sexuality, and even disparaged women themselves as unintellectual and antimodern. One of Loy's most complex autobiographical engagements with social gender conditioning appears in her long poem "Anglo-Mongrels and the Rose," first published in segments in The Little Review from 1923-1925. Melita Schaum describes this genre as "female autobiographical epic," and she points to the existence of a female modernist "sub-genre" that "defies trends against literary individualism" presented in other epic poems of the period such as T. S. Eliot's The Wasteland (255-56). In her development of a "valuable counter-poetic" (255), Loy presents an autobiographical account of her own life in order to comment upon the perpetuation of familial gendered divisions and hierarchies.

In "Anglo-Mongrels," a bildungsroman that narrates the development of an artist's aesthetic sensibility, Loy highlights repressive Victorian gender ideologies as they appear in the developing consciousness of the female child, "Ova." The young girl learns how gender is performed by observing her parents, and she eventually rejects gender ideologies that are based on economics and sexual repression. Loy constructs an autobiographical voice that represents a multiple and shifting sense of self, as Ova must learn to navigate received social scripts. More specifically, the poem charts a series of discoveries about the ways that gender and language perform as a pre-linguistic child gains language and learns how to internalize these performances and use them actively as a source of power and creativity rather than passive subjugation. 
The events and emotional realities Loy explores in "Anglo-Mongrels" move beyond a straightforward referential retelling of her coming-of-age. Loy's early experiences with language acquisition and her inclusive, artistic aesthetic as expressed in "Anglo-Mongrels" extends to the mythical realm. Notably, Alex Goody has argued that in "Anglo-Mongrels," "Loy's depiction and interpretation of her own life can be described as auto-mythological, that is, an individualized (and personally applicable) adaptation and conglomeration of an eclectic range of mythical structures and stories which fundamentally refutes the transparent process of personal realization celebrated in the Romantic artist-hero" (270). Of course, this idea of "automythology" involves the hero's journey to self-reinvention. In "Anglo-Mongrels" Loy creatively reconstructs her own coming-of-age: her struggle against Victorian gender and class conventions and her eventual triumph against all odds as she emerges as the modern artist-hero. To narrate this journey, Loy abandons both autobiographical transparency and literary individualism as she develops an inclusive, expressive, and performative voice.

Loy's critique in "Anglo-Mongrels" is not personal but social; she explores the domestic sphere as a space where the social and the mythic meet. For Ova, domesticity is built upon the relationship between her English mother and Hungarian Jewish father, a union based on flawed notions of purity and economics associated with English nationalism. The domestic space becomes a site of captivity for the young Ova, and she only begins to develop her artistic sensibility when she comes to identify with her father's outsider status. Loy creates an identifiable character in Ova, but I argue that a cohesive self is never achieved, nor is it really desirable. The broken, contingent, and disrupted autobiographical self that Loy represents more accurately reflects Ova's experience of language acquisition and her internalization of gender hierarchies. In retroactively narrating her journey to self-realization and presenting a creative and 
lyric account of her coming-of-age, Loy engages in a mode of identity performance. She presents a 'self' that is unstable and multiple by creating a poetic persona for her younger self while also asserting her voice and authority as author. The poem, then, is an example of performative discourse.

According to J. L. Austen the performative speech act distinguishes itself from other speech by doing something in the world, inviting action. ${ }^{4}$ Modern poetry often suggests "acting" in the sense of adopting a poetic persona or asserting a subjective presence. It is clear that Loy's characters in "Anglo-Mongrels" are biographical, but because she draws upon mythic structures and broader social realities her position of presence is more subjective and lyrical. The themes of language acquisition and identity performance featured in "Anglo-Mongrels" also appear elsewhere in Loy's poetic oeuvre. Most notably, her little-known poem "Child Chanting” offers a useful comparison, featuring the experimentation characteristic of the early linguistic stage that is instrumental to the development of the artist/poet. Loy's most famous and scandalous poetry collection, Songs to Joannes, demonstrates the full fruition of her poetic power, the personal, sexual, and expressive freedom she gains both because of and in spite of her repressive upbringing.

\section{“Jostled / between revolving / armored towers": Pre-linguistic Ova and the Feminine Ideal}

In “Anglo-Mongrels" Loy charts a child's internalization of Victorian gender ideologies as she slowly gains linguistic skills and understanding. At the level of plot, "Anglo-Mongrels" presents Loy's Victorian upbringing in London in the 1880s and 1890s. Ova must learn to navigate a complex and highly structured adult world. The poem's fragmented structure and imagistic scenes convey the experience of a child's initiation into the cultural constraints of the 
patriarchal social and linguistic order. Much of the anxiety and tension in the poem stems from Ova's vexed position as the "mongrel" child of her mother, "Ada," the conservative, Protestant "English rose" and her father, "Exodus," the immigrant Hungarian Jew. Loy presents this family dynamic within the confining context of the domestic sphere. By observing and taking direction from her parents, Ova learns how to navigate social scripts.

In “Anglo-Mongrels" Loy consciously critiques and satirizes constructions of Victorian patriarchy as well as femininity and domesticity. Elisabeth Frost observes, "Loy's strategy is not revolution or violent confrontation, but a parody of cultural symbols and a satiric voice that exploits the very traditions she critiques. The result is a poetry of effect rather than affect, a double consciousness that inhabits and maintains an ironic distance from poetic language and the heritage it represents" (150). By using parody, irony, and satire, Loy undermines Victorian social conventions while also critiquing the literary tradition of patriarchal individualism that stems from Romantic poetry. Loy's critique is not personal but social. Although some of Loy's other autobiographical writings include vitriolic attacks on her mother, for instance, in "AngloMongrels" the mother stands in as a representative and indeed a victim of the patriarchal Victorian social order.

For Ova, the essence of femininity is repression and rage, as embodied by her mother, while masculinity is represented by the hybridity and cultural displacement of her father. In the following lyrical passage from "Anglo-Mongrels" Loy isolates the pronouns "she" and "he" to emphasize the extent to which Ova's parents become the sole representatives of the gender divide in her developing consciousness: 
simpering in her

ideological pink

$\mathrm{He}$

loaded with Mosaic

passions that amass

like money (124)

The woman "simpers" in "ideological pink," a particular shade replete with sniveling selfrighteousness and representative of the perceived purity of English values and nationalism. "He" is comprised of a "mosaic" patchwork of "passions," no doubt a reference to his status as an immigrant and his profession as a tailor, but also his passionate desire not only for his wife, his virginal rose, but for what she represents nationally and economically. From a young age, Ova observes that relations between the sexes are dominated by political and economic realities; neither parent satisfies the others' sexual, emotional, or spiritual needs.

Loy's depiction of her mother and father demonstrates the ways in which the domestic sphere and indeed the English nation itself is built upon flawed notions of the relation between purity and economics. The first two sections of the poem occur before Ova's birth, before the entrance of the poetic persona or character, so Loy adopts her authorial voice to introduce each of her parents. Loy's depiction of her mother, an intimate figure, is fraught with irony. Loy satirically introduces Ada as the "Early English everlasting / quadrate Rose / paradox-Imperial" (121). The rose is the national flower and serves as the symbol of England. Ada represents a constructed innocence that includes sexual and national purity. Frost explains that in Loy's view the flawed state of English culture stems from an "over-bred, Victorian femininity." She also comments upon the symbolic implications of the rose: "Loy deflates the 'romance' of the rose, a 
national symbol which merely covers over the economic realities that confront — and define-its people" (159). Indeed, in the construction of the Rose, Loy unmistakably positions sexual purity within economic systems of exchange:

\author{
For of this Rose \\ wherever it blows \\ it is certain \\ that an impenetrable pink curtain \\ hangs between it and itself \\ and in metaphysical vagrance \\ it passes beyond the ken \\ of men unless \\ possessed \\ of exorbitant incomes
}

And Then-

merely indicating its presence

by an exotic fragrance (128)

The first two lines of this stanza contain the perfect rhyme of "Rose" and "blows." The doubleentendre, of course, consists of a rose gently blowing in the wind in a prim English garden and the sexual connotations of the verb "blow" and its association with orgasm. The English rose, Loy suggests, is a contradictory symbol, defined by purity yet tainted by sexuality. An “impenetrable pink curtain" of virtue divides the middle-class Victorian woman within herself, separating her from her own impulses but giving her body value in the male sphere. The construct of purity functions to raise women above physicality and sexuality until they are 
"bought" by men with economic status. Loy links economics with sexual desire. Ada offers her body in the male-centered market economy of marriage when Exodus displays "passions that amass / like money" (124). Even then she cannot give herself entirely, only a vague "exotic fragrance," for she does not possess a "self" to give. The Rose is a complex symbol; she possesses a fragile, conditional power in her purity and British pedigree, but it is dependent on her participation in the patriarchal economic order.

The marriage bed is the first site of defilement for the Rose, and the birthing chamber is the second. Ova makes her appearance in a memorable birth scene which can be characterized by bodily anxiety, repulsion, and guilt. Ova enters into the poem as "a clotty bulk of bifurcate fat" that is "pulled out" of her mother's body (130). Here, birth is neither celebratory nor idealized; it is a "grotesquerie" (130) presented in terms of severe discomfort and trauma. Birth is implicitly associated with sexual guilt. John Hawkins Miller highlights the contradictory Victorian view of woman as simultaneously "temple" and "sewer," ideally constructed as chaste but also unclean in her physicality. He explains that women were viewed as the "passive receptacle of male lust," their purity tainted by male carnal desire (41). Adrienne Rich also links childbirth with notions of sexual guilt. Birthing is an intensely physical act which is inextricably linked to female sexuality. Rich explores the attitudes toward birth in various cultures, noting that throughout history there appears "a deep and prevalent sense of the woman's body as magical, as either vulnerable to or emanating evil—as unclean, and as the embodiment of guilt" (164). Ada is grossly unprepared for the physical realities of sexuality and childbirth. Notions of purity and courtly love are violently exploded as the sickening physicality of birth repulses the young mother.

By comparing this account of childbirth with another of Loy's poems describing her own experience giving birth, it is clear how Loy's notion of gender identity and maternity developed 
in opposition to her imagined account of her mother's horror. In Loy's celebratory birthing poem "Parturition" she presents quite a different experience of bearing her own child. She exclaims, "Mother I am / Identical / With infinite Maternity / Indivisible / Acutely / I am absorbed / Into / The was-is-ever-shall-be / Of cosmic reproductivity" (7). ${ }^{5}$ Much of Loy's poetry, especially when she tackles certain subjects, takes on a cosmic or mythic dimension. As the speaker gives birth she describes her "congested cosmos of agony" (4), a state of physical pain so overwhelming it becomes "Exotic" (5). Yet in this most physical of acts, the mother transcends the temporal realm as her individual identity merges with "infinite Maternity" (7). While Loy's description of her own birth is characterized by her mother's constricting alienation from her own body, Loy's speaker in "Parturition" describes an elevated state of consciousness in which her physical body serves as the vehicle through which she glimpses eternity through the act of procreation. ${ }^{6}$ She marvels at the "stir of incipient life" against her thigh, "Precipitating into me / The contents of the universe" (6). Loy offers these two accounts of the intimate and transformative experience of childbirth in order to emphasize the radically different ways in which she and her mother internalized womanhood and motherhood.

The troubled relationship between mother and child lies at the center of Loy's construction of the domestic sphere in "Anglo-Mongrels." Clearly, the mother is frustrated and alienated by the mandatory social performance of her domestic role, and her daughter bears the brunt of her suppressed anger. As a female child, Ova's conditioning serves as a constant reminder to the mother of the restrictions placed upon women in Victorian society. Ova also represents her mother's carnality and physicality: "To the mother / the blood-relationship / is a terrific indictment of the flesh" (Loy 147). The mother perceives Ova's very physical presence as accusatory. The guilt associated with the Rose's tainted purity in the marriage bed and the 
birthing chamber is embodied in the person of young Ova. As a result, their relationship is presented in terms of oppression and entrapment. The mother's body, the primordial site of warmth and nourishment, is perceived as intimidating and suffocating in its oppressive physical nearness, yet emotionally she is cold and distant.

As a pre-linguistic child, Ova's formative relationship with her mother is crucial to her emotional and psychological development. In “Anglo-Mongrels" Ova experiences psychological trauma through her alienation from the mother-figure. In the section of the poem entitled "Psychic Larva" the young Ova is unable to articulate the depth of the wounds that she receives: "Lacking dictionaries / of inner consciousness / unmentionable stigmata / is stamped / by the parent's solar-plexus / in disequilibrium / on the offspring's / intuition" (148). The "stigmata" appears not on her body but rather it is seared into her subconscious. Frost notes that Ova's psychological and emotional alienation from the mother-figure at this pre-linguistic stage also undoubtedly affects her language acquisition. The mother/child bond in the poem is not described in terms of maternal comfort, but power and fear. Frost claims that the mother, or the “entrapping female" does "little besides mirror patriarchal domination," including disallowing the child's linguistic explorations and discouraging her "exploratory mind." Thus, the "disjunction between body and word" is parallel to the alienation that characterizes the relationship between mother and daughter (168). Ada is silenced and suppressed by the domestic construct, and her female child is destined to be bound by the same strictures.

One way in which Loy highlights the performance of femininity is through the movement of physical bodies and clothing; she positions the female body as both oppressive and oppressed. The adult women who surround the young Ova are presented as threatening, bristling "armored towers" (139) that overshadow and monitor her. The reference to "armor" characterizes the 
women as unyielding but it also functions as a more direct allusion to the restrictive nature of their clothing. Loy focuses on the tangible materiality of the domestic realm, particularly restrictive Victorian dress. The women are clad in "iron busks / of curved corsets" (140), their bodies enveloped in "heavy upholstered / stuffing" (139). The female body bound rigidly within restraining garments becomes a metaphor for the physical, sexual, and social repression of women by Victorian conventionality. In one particular scene, the child Ova associates her mother's body and clothing with an enigmatic sense of disturbance:

The mother draws near unnaturally

as if to assert her dignity

after some outrage that seems to rustle among her draperies drawn across her thighs to bunch over her bustle (138) The "draperies" veil the female body and also restrict it; the material is stretched across the mother's thighs. This reference to restrictive fabric recalls the "impenetrable pink curtain" (128) of virtue Loy includes in her first description of the Rose. The perceived "outrage" in this passage is a source of speculation. Perhaps the young Ova has transgressed, but Loy's language seems to suggest that the disturbance lies within the folds of the mother's garment. Her body beneath the draperies, the site of female sexuality, is the outrage. 
Although the figure of Ada represents entrapment within the domestic space, Loy indicts societal systems of oppression rather than individuals. Keith Tuma asserts that the characters in the poem are meant to act as a personification of stereotypical gender roles. Ova longs for her mother's touch, but feels only deep-seated resentment:

$$
\begin{aligned}
& \text { She is overshadowed } \\
& \text { by the mother's aura } \\
& \text { of sub-carnal anger } \\
& \text { restringent to the pores } \\
& \text { of her skin- } \\
& \text { which opening } \\
& \text { like leaves for rain } \\
& \text { crave for caressings } \\
& \text { soft as wings (147-148) }
\end{aligned}
$$

Tuma observes that the syntax in this passage is ambiguous; he suggests that perhaps both Ova and her mother crave caresses (189). For children as well as for women, the domestic sphere fails to function as a physically and psychologically nurturing space. As a young child sensitive to her parent's "solar-plexus" (148), or her psychic and spiritual energies, Ova senses her mother's “sub-carnal anger" psychically lashing out at her. This silent, smoldering rage within her mother is linked to the guilt and anger she experiences as a result of her forced submission within patriarchal structures of authority. However, this frustration is also paired with the suggestion of a delicate, longing sensuality that characterizes both mother and daughter. The "opening" and craving refers not only to female sexuality and the physical touch but also to outlets for creative inspiration and enlightenment that are subverted under the patriarchal gaze. 
Writing from the perspective of a pre-linguistic child, Loy creates a poetic persona who perceives the domestic space as a site of captivity. These sections of the poem are characterized by images of imprisonment; Ova is trapped in a world of silence and suppression, both in her limited ability to interpret and communicate but also in her gender conditioning within the domestic sphere. Loy carefully constructs her poetic voice through the character of Ova, showing that even through the fractured and limited vision of a young child, Ova is aware of shadowy images that restrict and oppress her, confining her to the narrow limits of socially prescribed female experience. She is hemmed in by a "receding / prison / of muscular authority" (136) that disallows physical or psychological transgression. In one scene the toddler Ova "stumbles to the fire" and "her consciousness [...] quickens / to color-thrusts / of the quintessent light" (136). She is quickly snatched from danger, but the episode is described in terms of a denial of enlightenment. The fire is described as the "Elysian / fields of flame" (136), a reference to the underworld in Greek mythology. For Loy, it functions as a symbol of knowledge and intellect, exciting Ova's mind and suggesting the existence of a world she cannot enter. Instead, she is "told to 'hush' / while thrust / into her baby-pelisse / of ruby plush" (135). The female role within the domestic sphere demands silence and obedience. Ova is relegated to an object position; she is obligated to submit to certain codes of conduct as adults force actions upon her physical body.

\section{Loy's Autobiographical Voice, The Gender Divide, and the Birth of the Poet}

As she narrates Ova's dawning self-consciousness and language acquisition, Loy develops the lyric "I" in fashioning her autobiographical voice in the poem. Cristanne Miller claims that for Loy, "self-naming was applied to poetry both as an assertion of linguistic agency and as an opportunity for identity performance" (51). In "Anglo-Mongrels" an adult Loy 
reconstructs her childhood experiences, bringing various levels of observation and reflection to bear on her subject. Sandeep Parmar notes a particular phenomenon that occurs in much of Loy's autobiographical writing involving the "interference of the "authorial voice" with the “autobiographical self”: “Loy’s narrative flow is occasionally broken by the self-aware interruption of the writing 'self'; she moves between the moments of childhood and reflection" (40). This technique of shifting between voices gestures toward a performative autobiographical voice. As J. L. Austin asserts, the power of the utterance makes something happen. In this case, Loy-as-author or the "authorial voice" "becomes" Loy-as-character or the "autobiographical self," as she creates a persona for herself as a young child. Loy-as-author then interjects or reflects on the experiences of Loy-as-character as she attempts to navigate a seemingly impenetrable and at times overwhelming adult world.

As an autobiographical poem "Anglo-Mongrels" engages with the construction of self in relation to others. Recent studies of autobiography emphasize the contingency of the "I," particularly the female "I". Explorations of women and autobiography emphasize the constructedness of the subject position. For example, Sidonie Smith and Julia Watson describe autobiographical narration as a "moving target, a set of shifting, self-referential practices": "In effect, autobiographical telling is performative; it enacts the 'self' that it claims has given rise to an 'I.' And that 'I' is neither unified nor stable - it is fragmented, provisional, multiple, in process" (9). ${ }^{7}$ Although Loy's character in "Anglo-Mongrels" demonstrates this unstable and constructed female self, Loy shows that even as the female subject is acted upon by outside forces and discourses she can actively and creatively work within and against those structures to develop her voice and identity. This persona that Loy develops uses language ironically and playfully to describe her own transformation into a poet. Of course, Loy's autobiographical voice 
in "Anglo-Mongrels" also involves lyric elements, and her fashioning of the lyric "I" is both modern and performative. In Romantic poetry the lyric "I" was often directly associated with the poet/speaker, while the modern lyric acknowledges the limits of this presumed intimacy. ${ }^{8}$ Not only does Miller assert that a poem is a "performative speech act" that functions similarly to a person in "everyday performativity," but she argues that a lyric poem is "even more performative" than the autobiographical voice because it "asserts a subjective presence" without always specifying its speaker (53). Throughout "Anglo-Mongrels" the identity of the speaker remains unclear; this is especially noticeable in the opening sections before Ova's appearance and in later lyrical sections of poem when Ova's consciousness merges with her imaginative reality. Reading "Anglo-Mongrels" as a performative speech act recognizes Loy's dynamic identity performance, her social critique, and her reliance on mythical structures.

It should be noted that Loy's autobiographical "I" is implied and not literal; as Ova arrives on the scene as a thinking being in "Ova Begins to Take Notice" and through the end of the poem, Loy writes the character in third person. This may seem to be an unusual choice given the genre of autobiography. Tuma explains the reasons behind Loy's point of view: "One might say that using the third person offers the poem some of the 'impersonality' valued by many modernist poets. But impersonality here is less an effect of Loy effacing herself from the poem than a technique for increasing a critical and ironic distance between herself as author of an autobiographical poem and herself as its subject, or one of its subjects" (187). In another performative move, Loy creates a character/persona for herself and adopts a narrator's point of view. This distancing is critical to the narrative development of "Anglo-Mongrels" because it allows Loy to narrate the story in retrospect, from the perspective of an adult artist and poet who can now reflect on her early struggles, inspirations, and influences. 
In autobiography the stakes are particularly high for women, since masculinity is represented by the post-Enlightenment ideology of individualism. Leigh Gilmore explains, "Men are autonomous individuals with inflexible ego boundaries who write autobiographies that turn on moments of conflict and place themselves at the center of the drama. Women, by contrast, have flexible ego boundaries, develop a view of the world characterized by relationships (with priority frequently given to the mother-daughter bond), and therefore represent the self in relation to 'others"” (xiii). Drawing upon the work of Gilmore, Ryan Claycomb describes an Enlightenment epistemology of self that features "the trope of the individual male who controls his own life such that it can be ordered into a coherent, linear narrative of which he is the center" (3). Claycomb explains that when this construct is applied to women's lives in autobiography "this individualistic formation of the coherent self has traditionally failed to center the woman as empowered subject but rather has positioned her as an object of observation" (3). Loy highlights this dynamic in "Anglo-Mongrels" in highly exaggerated contrasting portrayals of the childhoods of Ova and Esau Penfold, meant to represent Loy's first husband, Stephen Haweis. While the domestic sphere is characterized by images of entrapment, physicality, and suppression, the public, male-centered space focuses on intellectuality, dominion, and control. The five-year-old Esau appears at the center of an intellectual soiree, a costume ball held in affluent Ridover Square. He assumes the air of a monarch, an "Infant Aesthete" who appears in a "gossamer / Toga of Tyrian rose" and Christ-like, holds an orb in his hand (133). It is clear in this harshly satirical portrayal that all the wonders of the world, intellectual knowledge, wealth, and renown are lavishly heaped on this young boy by virtue of his sex and birthright. His life is his own to order and control, while Ova actively seeks worldly knowledge but is sequestered within the narrow confines of her prescribed gender role. 
While Esau wields the orb, the symbol of power and dominion, in a parallel scene that takes place in her home, young Ova repeatedly chases after a ball, a mere imitation of the worldly authority represented by the orb. The young Esau is erudite and highly articulate, discoursing with a professor of anthropology, while for Ova intellectual knowledge proves elusive. Ova’s small “orb of verdigris" (141) is associated specifically with language acquisition. A word begins as a "fragmentary / simultaneity / of ideas" (141) cohering in Ova's developing consciousness, and as she cogitates she fixates on the visual stimuli of the orb:

An unreal

globe terrestial

of olive-jewel dilates

evaporates

into the Increate

And as it vanishes

she crawls into the macabre

shadowiness

upon the floor

under the white valances

of the furniture

to look for it

She is pulled out by her leg (142)

Just as Ova senses a glimmer of knowledge and understanding represented by the orb, it eludes her. Ova is oppressed by a patriarchal order which will not allow her access to the intellectual 
world of Esau, and she is constantly held fast by "a woman's / ineludable claws of dominion" (136). Her mother harshly pulls her from a realm of "macabre shadowiness" where she seeks knowledge. Not permitted to desire anything beyond the world of "white valances," Ova is restricted by the ideologies of domesticity that define the female role. Of course, although this scene is written in third person, Ova is clearly a thinking, perceiving subject as she chases the orb, not in this case an object of observation. In an interesting reversal of the traditional autobiographical subject/object binary, Loy-as-author usurps the male gaze in her role as active observer and narrator.

While Esau represents a masculine world of power and control denied to Ova, her father, Exodus, serves as a more ambivalent symbol of masculinity. ${ }^{9}$ Throughout "Anglo-Mongrels" Exodus is portrayed more sympathetically than Ada and Esau. Although Exodus tricks Ova on two different instances in the poem, both occasions of confusion and disillusion for the young child, ultimately his ethnic hybridity and his work as an artist and tradesman inspires his daughter's creativity. At one point in the poem Ova and her father peek into Miss Bunn's basket of toy Japanese fishes and her father tells her not to admit to what they have done. Later, when she is asked by the adults, or "armored towers" whether she peeped in the basket she looks to her father and denies that she has. Immediately she is chided, called a liar, and turned out of doors. She suffers humiliation and bewilderment, vowing never to return to the realm of the "big bodies" (162). Instead, "she decides to travel," but then a hand, accompanied by "mocking laughter" pulls her back inside. On another occasion she asks her father for a sovereign and he gives her a shiny coin, at which "She is exalted / in spontaneous knowledge of beauty" (166). When she presents the coin to a flower seller on the street however, she finds that it is only a new farthing, and she has been humiliated again. While at moments like these Exodus's sense of 
humor represents for Ova the impenetrable mysteries and confusions of the adult world, at other times she identifies with her father.

From Exodus Ova inherits her ethnic hybridity, her creativity, and her intellectuality, or her "Jewish brain" (132), which Loy fancifully describes as being presented to Ova by a fairy godmother at her birth. Parmar observes, "Although there are moments in the poem when her father acts as unfairly as her mother, Exodus's metaphoric value as an exiled Jew and as an artist who was forced into trade aligns him with his daughter" (123). Indeed, the final section of the poem is devoted to Exodus and his profession. Loy elevates tailoring, a trade disparaged by men, to a creative act that parallels Jehovah's act of creation. Loy muses about her father: "'Man that is born of woman' / Perhaps he chose / A profession all too feminine" (175). Quoting from the book of Job, Loy alludes to the reality of human frailty and mortality, but also to Exodus' somewhat suspect masculinity. Of course, the act of creation is "all too feminine," as well; the "mongrel" Jewish tailor is emasculated by nature of his ethic heritage and his profession. In a series of complex metaphors and reversals, Loy reflects upon man's “amorphous nature” (175) and the "man-made God" (174). The tailor is created by God, yet also creates God in his image. The tailor's role in humanity is to help others to conform to the dictates of fashion, an important mode of gender performance. Thus, the character of Exodus, by virtue of his craft, does not conform to the dictates of Victorian masculinity. Additionally, this idea of stitching things together, the use of cutting, form, and pattern in the act of creation reflect Loy's own methods in writing the poem and fashioning her own voice. Ova's perception of her father's role as outsider and creator affects the development of her own artistic sensibility.

In the poem, the sections that address Ova's language acquisition are also associated with the early development of her visual artistic sensibility. In the section entitled "Ova Begins to 
Take Notice" her early consciousness is comprised of color and light, which she uses to individuate and imagine herself for the first time as a perceiving being: "The prismatic sun show / of father's physic bottles" [...] "Her entity / she projects / into these sudden colours / for selfidentification" (137). It is certainly significant that the objects Ova contemplates are her father's bottles of medicine, reflecting a prism of light as they stand in the sun. In projecting onto them, she recognizes herself as a separate entity yet perceives some affinity between the world and herself.

In another transformative moment for Ova, this one associated with her mother, she connects a linguistic utterance with a color. In an overheard conversation between Ada and a nurse over the bassinet of her newborn sibling, she perceives the word fragment "iarrhea," and "It is / quite green" (140). This is the first time her developing consciousness recognizes a linguistic sign and associates it with a color. As a result, the young Ova develops "an obsessional / color-fetish" (141). Since she lacks the real referent for this linguistic sign, she associates diarrhea with something transcendent, a flash of understanding which associates a word with a visual sign. Loy sums up these formative experiences thus: "So did the mongrel-girl / of Noman's land / coerce the shy / Spirit of Beauty / from excrements and physic" (143). Ova's artistic sensibility develops even from within the restrictive environment in which she finds herself. The ideology of Victorian domesticity which disallows transgression nevertheless cannot quell Ova's exuberance and triumph as she begins to comprehend language. Even as she is being introduced into a patriarchal linguistic order, there is some element of linguistic play. In the poem, Loy narrates her early discovery of the ways that language can perform, how it can transcend the purpose for which it is intended. A linguistic sign like diarrhea is dissociated from 
its rather disagreeable referent and comes to represent an introduction into a newfound state of awareness.

As the child Ova grows older, she constructs an imaginative dream-world outside of her everyday experience, and it is from within this world that she develops her poetic voice. This is when Loy’s created character Ova begins to come into her own. In Loy’s biography, Burke explains that as a child Loy was often unhappy and dissatisfied at home, and she sought escape through friends and relatives but also through her construction of a "land of her dreams" (24-25). There are moments in "Anglo-Mongrels" that seem to reference this imaginative reality. The brief section entitled "Illumination" finds Ova alone in the garden as "the high skies / have come gently upon her / and all their / steadfast light is shining out of her" (163). This scene is presented in terms of an enlightenment as "she is conscious / not through her body but through space" (164). This moment comes as a reprieve from the adult world, which Ova refers to as "the long nightmare" (164). In this world, Ova often feels conspicuous, confused, and ashamed. Conversely, in the garden Ova is allowed to truly be, and only then does she begin to uncover aspects of her own identity, including her creative impulse. It is from within this space that Ova/Loy creatively explores her gendered identity and develops her poetic voice.

Among her papers at the Beinecke Rare Book and Manuscript Library at Yale there is a poem by Loy entitled "Child Chanting” which brilliantly captures this early linguistic stage. This little-known poem was translated from French and published in the collection The Last Lunar Baedeker (1982). In an urban yard an unseen child chants a little song, and Loy returns repeatedly to the simple refrain, "A dolly - - - a daisy - - -." The first part of the poem describes the urban landscape and identifies the child's voice as it softly trickles through the tenements, 
while the second half muses about the unselfconscious verbal utterances of children. The poem concludes thus:

"A dolly - - - a daisy - - -
Eulogy
idolatry
frail expulsion
of incantation
Infancy's idiotic
angelic
preference for iterance
"A dolly - - - a daisy - - _“

Concealed baby,

your shrill voice, rising,

quickens the air's glistening (Box 5, folder 85)

The innocence and simplicity of this refrain, the words apparently only linked by alliteration and some abstract connection in the child's mind, conceal a linguistic and psychological complexity that Loy brings out in the poem. Children have a preference for iterance which is both idiotic, because the child cannot grasp the full import of language, but also angelic in its innocence. Despite the gently playful overtones, there is a seriousness and earnestness to this utterance as words function as idols that inspire the child's worship and solemn praise. This is an example of a simple and unselfconscious speech, but Loy alludes to the gravity of the child's linguistic act 
by describing it as "incantation"; this utterance has the power to conjure, the potential to make something happen. That this simple refrain "quickens the air's glistening" attests to its evocative power.

This acquisition and evocation of language, however, can also traumatize the child. In "Illumination" Ova begins to feel the freedom associated with individuation and expression; however, in the section of "Anglo-Mongrels" following "Illumination" Ova's transcendence is quickly followed by a violent contraction:

The garden

the child's

first place of purity

is become defiled

An egg is smashed

a horrible

aborted contour

a yellow murder

in a viscous pool (164)

The fact that this traumatic loss of the child's "illuminated" state as well as the purity of childhood is signified by the smashing of an egg seems especially significant. Loy not only reminds the reader of the fragility of the child's innocence but also alludes to the significance of her name "Ova," or ovum, the female egg cell. Ova first projected her being onto her father's physic bottles; in this case she identifies with the smashed egg, horrified at the chickens who are "pecking the gravel in unconcern" (164). The garden, the primordial place of innocence, comes 
to represent life and death as well as knowledge of the harshness of mortality. Along with language acquisition and the possibility for self-expression comes difficult knowledge; with illumination comes contraction.

The authorial Loy identifies closely with the character Ova in these lyrical and transformative sections of the poem as she begins the intricate process of developing her aesthetic consciousness. According to Goody, Loy's poetic voice is situated “in the intersection of the poetic/lyric 'I' with autobiographical self-inscription." Whereas poetry "has its own truth... which returns the poem to itself," autobiography "functions through a different structure of truth which reaches out beyond itself" (63). Poetry functions as a closed system of reference, whereas autobiography is assumed to have some textual relation to the "real." In the conjunction of the poetic "I" and the autobiographical, personal "I" Loy finds her poetic performance space.

While her gender conditioning within the narrow confines of the upper middle class Victorian home stifles Ova as a child, it also begins her journey toward learning how to express herself by performing in language, which is a major part of her performance of femininity. She engages in intellectual language play and develops a performative autobiographical voice to tell this story of the beginning of her journey. Parmar notes that the impetus for Loy's autobiographical writing stems from the "self-expressive impasse caused by her racial hybridity, her desire to write in spite of the guilt induced by her parent's censorship and finally, the responsibility of the artist to depict a cohesive self with which an audience may compare their own lives" (109). Loy does create an identifiable character, but I would argue that a "cohesive self' is never achieved, nor is it really desirable. The broken, contingent, and disrupted self that Loy represents more accurately reflects her experience of language acquisition. "AngloMongrels" is ultimately the story of an artist/writer finding her performative voice, the 
Bildungsroman of a prelinguistic child whose world is ordered by Victorian social constructs on the path to becoming an artist who wields her modern performative persona like a weapon.

\section{Loy as Punk Rocker: Songs to Joannes}

Loy's performance of femininity, described in “Anglo-Mongrels," plays out in her writing throughout her career. Notably, the poetry collection Songs to Joannes, published in segments between 1915 and 1917, became Loy's bold introduction into the American literary scene. The collection was notorious for its frank depictions of female sexuality, which many of Loy's contemporaries found disturbing. In fact, after reading Songs to Joannes Amy Lowell refused to have her own work appear in the same publications as Loy's. The oft-quoted first poem in the collection, first published in Others in 1915, features the infamous "Pig Cupid his rosy snout / Rooting erotic garbage" (Loy 53). In Songs to Joannes Loy urges greater sexual awareness and calls attention to relations between the sexes by exploding conventional portrayals of love. Her use of free verse and her overtly erotic subject matter offer an alternative view of love as expressed in lyric form. She works to counter a tradition of idealized romantic love, portraying instead the intimate, gritty reality of sexual encounters from a female perspective. Nicholls notes that certain modernist poetry is characterized by an “'erosion' of a presumed intimacy [that] is produced in part by insistent gyrations of tone and register that in a variety of ways 'break trust' with the presumed proximities of the lyric voice" (177). Just as in "AngloMongrels" Loy disrupts the "intimacy" of the traditional lyric "I," in Songs to Joannes she maintains that distance and irony in her linguistic experimentation as she tackles more controversial subject matter. 
Songs to Joannes is comprised of a series of brief poetic vignettes describing various shades of a particular sexual relationship. Specifically, the collection details Loy's complex love affair with Italian futurist Giovanni Papini. Published six years before "Anglo-Mongrels," Songs to Joannes portrays not the child gaining understanding of gender, but the mature woman freely exploring her sexuality. Using language that is at once cerebral, imagistic, and metaphorical, Loy renders depictions of the fleeting glory, but also the frustrations, impotencies, embarrassments, and miscommunications that define human love and sexuality. The following stanza is notable for its focus on the transcendent nature of sexuality:

Today

Everlasting passing apparent imperceptible

To you

I bring the nascent virginity of

-Myself for the moment

No love or the other thing

Only the impact of lighted bodies

Knocking sparks off each other

In chaos (58-59)

That love in the present moment could be both "everlasting" and "passing," both "apparent" and "imperceptible," attests to sex as a celebratory act that transcends temporality. Far from defiling her, this sexual act, stripped of love or "the other thing" (perhaps hate), cleanses the speaker; she possesses an emerging purity in the now. Unlike the overbred Victorian femininity of Loy's mother, the English rose, this purity is defined by freedom, individualism, and power. 
In her attempts to access, capture, and describe what it is that lies at the center of this web of passion, emotion, and carnality, Loy uproots "Love," the "preeminent litterateur" (68). It is at once a sweet cascade of sensation, a vision of a "cosmos / of colored voices / And laughing honey" and in the following stanza, a cold bodily exchange comprised of "Spermatozoa / At the core of nothing / In the milk of the Moon" (56). The reader accompanies the speaker on an exhausting journey of emotional switchbacks, pulls, and bounds, as she attempts to poetically represent the complex and often contradictory realities of human sexuality. Rachel Blau DuPlessis claims that Loy rejects a sentimental and romantic tradition not only in her subject matter but also in her narrative strategies (66). She disrupts the conventional alignment of sexual climax with narrative climax. The love affair that she describes in Songs to Joannes is nonlinear; the narrative is prone to circularity, disruption, and disjunction. In her honest appraisal of love and sex, Loy calls attention to the distractions and interruptions of the world outside of the lovers and its effects on their intimacy: "Voices break on the confines of passion / Desire Suspicion Man Woman / Solve in the humid carnage / Flesh from flesh / Draws the inseparable delight / Kissing at gasps to catch it" (57). Even within the sexual embrace outside voices intrude; petty jealousies and insecurities interfere as the speaker attempts to illustrate relations between essential "Man" and "Woman." Loy's aim is to expose the ways in which traditional romanticized love and sexuality involve female subjugation. Throughout Songs to Joannes Loy tends to essentialize and mythologize the functions of femininity and masculinity, and she believes procreation is a major function of the intelligent, sexually liberated woman. ${ }^{10}$ Although Loy rejects the romantic tradition in the style and content of her poetry, her rather conservative position on reproduction fails to take other sexualities and sexual practices into account. 
In many of her early poems Loy focuses on sexual as well as social issues of gender, marriage, and intimacy; however, Loy was not interested in political feminism. In fact, she openly disparages the feminist movement in her "Feminist Manifesto," calling for women to break out of the narrow categories the patriarchy has established for them not by entering "professional and commercial careers," but by abandoning the harmful notion of "virtue," breaking out of repressive relationships, and freeing their sexual and procreative potential (153155). ${ }^{11}$ According to Virginia Kouidis, Loy "analyzes the female self as she sees its universal situation mirrored in her own life and in the lives of her contemporaries" (26). She critiques socially-constructed gender categories through the lens of her own experiences, attempting to escape these pervasive structures in the process of defining herself as a liberated "new woman." Indeed, David Ayers notes that in Songs to Joannes Loy explores the nature of "bohemian" and "unmarried" love (36). Positioning her speaker as a woman who pursues her lover, Loy shows the liberty and also the dangers of free love. Ayers claims that many avant-garde artists of this time believed "the truths about individual desires were smothered by the bourgeois convention of marriage," (37) and they sought to expressively escape the relational structures defined by society. Although Loy considered her contributions to feminism to be largely artistic and not political, some of her work aligns with the goals of the feminist movement. Burke draws connections between Loy's project and the political activism of certain women of the time such as Mabel Dodge, Margaret Sanger, and Emma Goldman, who advocated for sexual liberation. These women were political and social radicals who opposed patriarchal sexual authority and promoted female sexual knowledge and freedom. Burke explains, "Loy was sympathetic to efforts for greater sexual honesty, which she saw as a prerequisite for psychic and social liberation" (41). Indeed, in her "Feminist Manifesto" Loy warns that "the woman who is so 
incompletely evolved as to be un-self-conscious in sex, will prove a restrictive influence on the temperamental expansion of the next generation" (154). Despite her reluctance to participate in the feminist movement, Loy believed that sexual freedom for women was crucial to gaining creative and political liberation.

In Songs to Joannes Loy pushes the boundaries of Victorian poetic conventions, baffling critics with her intellectual experiments in language and syntax and her brash intermingling of the aesthetic and the spiritual with shocking eroticism and scathing satire. Rob Sheffield compares Loy to a punk rocker who shatters convention with style and language play: "She had a forbiddingly erudite vocabulary, drawing words from all over the language and beyond, and yet her propulsive beat made even her most convoluted lines seem chatty and spontaneous. Like any great punk rocker, she was inspirational because she trusted her own sense of forward motion, plunging ahead, making up her own words when it would take too long to bend an extant one into the right shape, spilling language promiscuously" (626). However incongruous it may seem at first, Loy's anti-establishment aesthetic and her aggressively modern lyric make this an apropos comparison. As Sheffield suggests, self-confidence, linguistic promiscuity, and "forward motion" are the defining characteristics of her oeuvre. Even in the face of criticism and misunderstanding as others tried unsuccessfully to categorize her work and narrow her vision, Loy trusted in the innovative verse she was creating, not only in her sense of rhythm and use of unconventional language, but also in her unconstrained exploration and revision of traditional gender ideologies.

"Anglo-Mongrels" is a lyrical exploration of the development of Loy's aesthetic sensibility, a story of the early inspiration that led to groundbreaking works such as Songs to Joannes. Both in form and content Loy engages in a performative mode of writing in "Anglo- 
Mongrels" that transforms the traditional lyric "I" and complicates referential autobiographical narration. The performative dimensions of the poem are directly related to the creation and evolution of Loy's artistic identity. If the performative utterance makes something happen, as Austin asserts, then Loy's language acts by conjuring an imaginative world into being. This evocative power of language is notable in the work of Barnes, Bennett, and Millay as well. The work of these women highlights their efforts to wield language in such a way as to make not only a political or social statement but a tangible change in the world. This writing is a call for action. 


\section{Notes}

${ }^{1}$ Logopoeia is one of the three kinds of poetry defined by Ezra Pound. The others are melopoeia, which involves sound and rhythm affecting emotions, and phanopoeia, which focuses on the visual imagination. See Pound, Literary Essays of Ezra Pound.

${ }^{2}$ For more on Loy's outsider status see Keith Tuma and Maeera Shreiber's introduction in Mina Loy: Woman and Poet. Tuma and Shreiber attest to Loy's eclecticism and materialism as well "generic restlessness" and her "radical skepticism toward language" (13).

${ }^{3}$ The major works that began to reestablish Loy as a major modernist writer include Kenneth Rexroth's "Les Lauriers Sont Coupés: Mina Loy" (1944) and Kenneth Fields’s "The Poetry of Mina Loy" (1967). A major critical resurrection of Loy came in the 1990's with the simultaneous publication of The Lost Lunar Baedeker (1996), a collection of Loy's works extensively edited by Roger Conover, and Carolyn Burke's biography, Becoming Modern: the Life of Mina Loy (1996).

${ }^{4}$ In "How to Do Things with Words" Austin proposes the term "performative" for a wide variety of performative statements including contractual and declaratory utterances (7).

${ }^{5}$ In "Parturition" Loy linguistically replicates the process of labor and contractions using alternating line lengths, representing climbing and falling.

${ }^{6}$ See Peppis’s “Rewriting Sex" and Lyon's “Mina Loy’s Pregnant Pauses” for a discussion of biological reproduction as aesthetic reproduction in "Parturition."

${ }^{7}$ Leigh Gilmore argues a similar point, explaining that "Autobiography is positioned within discourses that construct truth, identity, and power, and these discourses produce a gendered subject" (xvi). What emerges from these studies is an autobiographical female self that is unstable, defined by discourses of power, and relational. 
${ }^{8}$ According to Peter Nicholls, modernist lyric undermines the lyric's "traditional assumptions [...] of self-sufficiency, of its capacity to constitute an autonomous, seductively suspended world" (177). The modern lyric is much more fraught; it moves beyond direct referentiality, mediating and experimenting with voice and signification.

${ }^{9}$ The third male character in the poem is the hyper-masculine Colossus, meant to represent Loy's lover Arthur Cravan, who disappeared and was presumed dead in 1918. Loy devotes a brief section of the poem to him.

${ }^{10}$ Loy's ideas about sexuality and procreation appear in her "Feminist Manifesto," which she wrote partly as a response to Futurism. Laura Scuriatti's "Bodies of Discomfort" explores the "contradictory status of the female body" in Loy's "Feminist Manifesto." While denouncing Futurist characterizations of women as anti-modern and disparaging the "marriage market," Loy essentializes the female body by emphasizing women's "responsibility toward the race as mothers and their sexual potential as lovers" (132).

${ }^{11}$ Loy states, "The feminist movement as at present instituted is inadequate $[\ldots]$ Cease to place your confidence in economic legislation, vice-crusades \& uniform education-you are glossing over reality." She calls for a revolution in which women no longer have to choose between “parasitism, \& prostitution—or negation" (“Feminist Manifesto" 153-154). 


\section{Epilogue}

The Legacy of Performative Writing:

From Modernism to Contemporary Lyrical/Critical Writing

For writing is a practice - a practice in which the author disappears into a process, into a community, into discontinuities, into a desire for discovery.

-Rachel Blau DuPlessis, “The Pink Guitar”

The lyric essay, as some have called the form, asks what happens when an essay begins to behave less like an essay and more like a poem. What happens when an essayist starts imagining things, making things up, filling in blank spaces or-worse yet—leaving the blanks blank? What happens when statistics, reportage, and observation in an essay are abandoned for image, emotion, expressive transformation?

-John D'Agata, The Next American Essay

It is possible to chart a trajectory of performative writing from these modernist women through contemporary literature. Barnes, Bennett, Millay, and Loy, among other early twentieth century writers, were instrumental in laying the foundation for late twentieth century and twentyfirst century performative writing, including poetry, lyrical/critical writing, and experimental criticism. By focusing on the body, representing cultural, gendered, and racial performances, and breaking down generic and disciplinary categorizations in their writing, these women began to imagine new modes of literary expression that have political and social consequences in the world. For some of these writers, particularly Bennett, whose work has only recently been 
rediscovered, much still needs to be done to trace the ways in which their aesthetic influenced other writers and artists.

Insofar as the work of the women in this study help us to consider literary form as an activity or performance, as enacting disruption, tension, fracturing, joining, and juxtaposing, it influences contemporary lyrical and experimental literary criticism. Called lyrical/critical writing, creative criticism, avant-garde criticism, or creative critical writing, this form or genre combines traditional literary analysis with poetic, essayistic, or personal writing. This genre of writing is inherently performative as it involves a dynamic relation between writer and audience, disrupts generic categories, calls attention to its passing, and attempts to "make something happen" (J. Hillis Miller 78), as opposed to providing knowledge. Some contemporary lyrical/critical writing has its roots in modernist formal experimentation, theater and performative writing. The female modernist writers in this study paved the way for this kind of literary criticism by enacting interplay between genres and imagining new ways of performing the self.

Contemporary critics have attempted to analyze and illustrate this move toward creative or experimental criticism. In his 1999 article "The New Belletrism" Jeffrey Williams discusses the emergence of "personal criticism," "autobiographical literary criticism" or "confessional criticism" that became popular in the 1990s and opposed the "High Theory" of the 1970s and 1980s. Williams describes this style of writing as more literary and experiential than theoretical. In explaining the impetus behind this writing, he focuses on audience engagement:

In this reconfiguration of audience and audience expectations, these modes project a revised public rationale for the profession of literature that justifies itself 
by conspicuously re-embracing familiar, more popular literary modes such as the personal essay or literary journalism. They reconfirm our disciplinary object as literature, and our professional creed as the appreciation of literature and culture and traditional literary values such as the expression of emotion and the human spirit. (417)

Interestingly, Williams describes an experimental mode of criticism that returns to traditional literary values. His article focuses on conditions within the academy that led to this shift, but he does not include an in-depth analysis of the hybrid forms and styles that characterize personal criticism. More recently, works such as John D'Agata's The Next American Essay (2003) attempt to lay out literary history of the lyric essay. The anthology features representative lyric essays written from 1975 through 2003 by authors such as Jamaica Kincaid, Annie Dillard, Sherman Alexie, and David Foster Wallace. D'Agata not only reclaims the essay genre but also actively edits, inserting his own narrative of historical context and commentary as well as his personal history in between the essays. According to D'Agata, the lyric essay “takes the subjectivity of the personal essay and the objectivity of the public essay, and conflates them into a literary form that relies on both art and fact, on imagination and observation, on rumination and argumentation, human faith and human perception" (436). Collections such as D'Agata's highlight the variety and trajectory of performative writing as it has developed over the last several decades.

One way to theorize the rise of lyrical/critical writing and contemporary personal criticism is to place it in the context of the current cultural and political situation, as well as academic, professional, and institutional realities. However, I am more interested in tracing various elements of this genre back to modernist performative writing. A study of lyrical/critical 
writing must necessarily include not only its personal or literary components, but also style choices such as the use of collage and fragmentation. Specific stylistic and thematic elements in lyrical/critical writing were earlier mobilized by the modernist women in my study. For example, Barnes demonstrates writing the body when she shows how physical violence becomes textual violence that plays out across the page. For Bennett, as for many writers of lyrical/critical work, creative expression acts as a direct response to systemic oppression. Millay's methods of diegetic narrativity and metatheatrics not only anticipate Brecht, but also prefigure a conscious attention to form and metanarrative elements. Finally, Loy's complex narrative voice involves an autobiographical telling that is performative in its lyricism and its expression of a self in flux, unstable and fragmented. The "I" in lyrical/critical writing tends to be more personal and process-based, while the academic "I" of traditional literary criticism tends to imply expertise, organization, and a linear progression toward an answer or conclusion. The lyric "I" that appears in "Anglo-Mongrels" is Loy's performative autobiographical voice, in which she asserts "the self-aware interruption of the writing "self"' (Carolyn Miller 40). These themes and narrative techniques form the basis of a writing style that combines critical rigor with experiential reflection.

The lyric essay is a perfect medium to combine personal narratives, realities and memories with academic discourse, all while focusing on craft and form. In an interview, Mark Doty explains the reasoning behind his lyrical writing style: "There is a place for purely theoretical criticism - the conversation of specialists—-but there are readers hungry to think about art, to engage with thoughtful, accessible writing that considers works of art within a broader human framework than most academic writing allows" (King). However, it is important to remember that this writing is not merely decorative or confessional. In the absence of a linear 
narrative and the conventions of academic criticism, it involves discomfort, lack of closure, and imprecision. It does not hide the struggle; it invites the reader into it. Two essays from feminist post-modern critics of the 1980s and 90s, Rachel Blau DuPlessis' "The Pink Guitar" and Juliana Spahr's Spiderwasp or Literary Criticism, are excellent examples of this combination of academic scholarship, social activism, and intimate personal narrative.

DuPlessis's essay “The Pink Guitar" is an intimate and at times difficult reflection on female writing and expression. DuPlessis explores form as an activity, placing "the shapes of social structures into relation with the shapes of art" (300). DuPlessis articulates what she hopes to accomplish with her form: "I wanted not catharsis but engorgement, not mimesis but uncovering, not mastery by plurality, not a 'form' but a method—of montage, of interruption-" (300). DuPlessis calls for a writing that is "multidiscursive, interrogative, polyvocal, heterogeneous, and interactive" (304). She stresses that the struggle associated with this kind of expression is not "decorative," rather, it is "a practice of interference, or trying to stop a normal, normative, coherent, flowing, and consumable practice" (314). Using the metaphor of plucking a guitar, DuPlessis wonders "how to unpick everything and still make it 'formal,' 'lyric,' 'coherent,' 'beautiful,' 'satisfying,' when these are some of the things that must be unpicked" (298). DuPlessis raises a host of crucial questions: How can we theorize and analyze a method of writing that resists and consciously disrupts theory and analysis? How can we find form and order in a mode of writing that invites chaos in montage, snapshots, fragmentation? And how is lyrical/critical writing related to narrative when it defies traditional modes of storytelling and flies in the face of conventions of literary criticism?

"The Pink Guitar" echoes the theme of gendered spectatorship and the physical and textual violence of Barnes's journalism. DuPlessis begins her article with an exploration of an 
Ingres painting that engages with the politics of gendered spectatorship. The Large Bather features a nude woman in a domestic interior with her back turned toward the viewer. Many of Ingres's paintings involve a voyeuristic view of female bodies in private spaces such as harems and baths. DuPlessis takes this dynamic as her starting point, exploring intersections between physical and textual violence against women. Referring vaguely to "lunchboxes of violence" that "wander across the page" (303), DuPlessis's descriptions of writing that is neither whole nor fragmented but symbolic and subversive recalls Barnes's performative journalism. "If this language seems defenseless, unguarded," asks DuPlessis, "if it mentions certain blood, if it strips itself and waits for impulsive behaviors to strike, waits for the play of association, if it provokes feelings of bemused recognition at quotidiam (sic) interruptions then what? From what is she writing?" (311). When Barnes is force-fed in prison to bring attention to a disturbing practice that violates the female body, her writing demonstrates her own vulnerability as the representative victim of a human rights violation. DuPlessis asks, "What body, then, is speaking? ... A body to whom things have happened AS a female body-" (310-311). Whether analyzing voyeuristic responses to everyday performances or placing her body in danger in her role as female stunt reporter, Barnes's writing exposes violence done to women's bodies and attempts to intervene in that aggression.

DuPlessis's essay also incorporates thematic and formal elements of Bennett's column "The Ebony Flute." In perhaps their most obvious link, the title of both pieces uses a musical instrument as a particularly apropos metaphor for creative female expression. "My pink guitar has gender in its very grain," (298) writes DuPlessis, just as Bennett's ebony flute is deeply imbued with racial resonances. The writing of both Bennett and DuPlessis espouses a strong belief in the power of expressive culture and creative expression as a response to systemic 
oppression in the form of racism or sexism. Bennett would likely concur with DuPlessis's assertion that "If one sees inside one's gender, class, race, sexuality, nationality, and these from and engaged with one's time, then culture is a process of rereading and rewriting, a practice" (306). In terms of form, DuPlessis favors montage and interruption over linearity and consistency. Bennett's style in "The Ebony Flute" is informal, conversational, and meandering. While Barnes and DuPlessis explore what it means to write the female body, Bennett negotiates a body that is doubly-inscripted, both female and black. In her account of a conversation with Frenchman Rene Maran she experiences a sense of kinship in the face of violence based on "the irradicable (sic) black of our skins" (August 1927, 243). While race cannot be reduced to physical appearance, this reference to skin emphasizes the physicality of writing the body and the potential liberation involved in this practice.

Juliana Spahr's essay Spiderwasp or Literary Criticism is comprised of a lyrical, personal narrative rich with metaphor on the left-side pages, and literary criticism exploring contemporary poetry and poetics on the right-side pages. Spahr describes the tension between fracturing/breaking down and joining/transformation, but she also demonstrates these realities in the very structure of her essay. Both structurally and visually Spahr's essay enacts the aesthetic of joining she describes. She explores poetry and literary criticism on a meta-level, investigating their efficacy as genres and linking them to the corporality of the body:

In the comparison that he or she is using, the literary criticism stands for many moments when legs, arms, bodies, touch. It is the hinge, the flip, the change in perspective. It is transition work. 
Its pages are always opening, opening. Its lines

Are always ending and returning. It is always

broken open, broken open. It cries.

In relation one person takes a bit of another

person, takes a fragment of that person, and lets it

into that other person.

In literary criticism, the same thing happens.

Like a bridge that joins two things together. $(104,106)$

How often in academia do we think about what literary criticism can do? Many times we take its power for granted. As Spahr lyrically reminds us, literary criticism is analogous to the body, the human in relationship with others. It opens rather than closes down, bridges rather than divides, unites us by what is truly human. This breaking open can also be painful however, as fractures and fissures create pain and uncertainty. In a meta-critical moment, Spahr explains the purpose of the personal, autobiographical commentary on the left-side pages: "The commentary is designed to be narrative so as to cover up the fragmentary nature of quotation. This is the way it is with thinking, with gendering, with joining. Forms can carry all ethical positions, like people, all the positions, all the meetings and dividings. We are transition work" $(108,110)$. Narrative, fragmentation, form itself, is an ethical position. Form bears the weight of meaning, orients us within a genre, satisfies or defies a host of writerly conventions. Spahr states that both literary criticism and we ourselves are "transition work"; we find the seams, the spaces in-between, and we explore, break open, and mend. 
Like Millay’s Aria da Capo, Spiderwasp incorporates elements of diegetic narrativity. Spahr's piece includes extra-textual elements such as copious endnotes to support the literary analysis on the right-side pages and brief italicized notes or headings to direct the reader through the lyrical, personal narrative on the left-side pages. Sometimes these read very much like stage directions. For example, "(that evening, those next few days)" (96) orients the reader temporally within the narrative. These notes can be read similar to Millay's detailed prompt book, as stage directions that aid the reader in navigating the performance script. Spahr labels the literary analysis section "ADDENDUM," as if it is supplemental to the lyrical autobiography. The literary criticism stands beside the narrative, but it is to be regarded as additional material. Spahr also includes a great deal of metanarrative comment, referring to the "narrative" or the "story" on the right-side pages and the "essay" on the left-side pages. She introduces the lyrical section with "This is the plot of his or her narrative" (90), foregrounding, narrating, and explaining. In Aria da Capo there is a great deal of metanarrative as well-the characters are aware of their own theatricality. Like Brecht, Millay does not invite the reader into comfortable and traditional theatrical mimesis. Similarly, the experience of reading Spiderwasp is disruptive in a way that makes the reader consider the exigencies of form. The very constructedness of the form or genre is constantly and directly alluded to in both Aria da Capo and Spiderwasp.

Both the narrative voice and the theme of poetic and personal transformation in Spiderwasp recall Loy's “Anglo-Mongrels." Spahr employs something similar to Loy's lyric "I" in her essay. In the literary analysis sections she remains (for the most part) in the impersonal academic third person. At one point in her discussion of contemporary poet Lisa Jarnot, Spahr refers to a "narrational I whose identification wanders" (97). Like Loy she uses third person pronouns in the personal, autobiographical sections as well, but the "I" is implied, denoting a 
multiple and shifting sense of self. Thematically, Spahr engages with joining and transformation. Her overarching metaphor is the story of the pepsis wasp who lays her eggs on the body of a tarantula, first lying in wait and then paralyzing and killing the tarantula when he emerges from his burrow at night to search for a mate. Spahr explains how the story of human relation parallels the story of contemporary poetry: "Both these examples are creation myths that literalize the name avant-garde" (93). "Anglo-Mongrels" relies on mythical structures to narrate a transformation as well. The early gendering of the child forms her aesthetic consciousness. Like the pepsis wasp and the tarantula, this is a transformation that has everything to do with the link between the social and the aesthetic. For Spahr, "This is the story of human relation - the one ripe with reproductive desire outsmarting those out at night, almost blind in the dark, looking for a mate" $(92,94)$. The older structures of patriarchy, of literary criticism, the "powerful masses...brought down by passivity" (92), give way to new structures that are cunning, imaginative, and prolific.

Lyrical/critical writing disrupts modes of reading and criticism, makes us question why those exist in the first place, where they came from, and how they serve us and fail us. The essays of DuPlessis and Spahr are structured not by the conventions of academic criticism, but by experiential knowledge. The essays demonstrate what they describe rather than conforming to an established set of conventions. In defying generic categories, however, these writers expose the reader to the struggle on the page, the search for an appropriate form to serve as a vessel for these ideas. This can make for an uncomfortable and unfamiliar act of reading and analysis, but it forces us to revise the conventional ways we read and respond. In these nontraditional modes of criticism the contributions of modernist women writers such as Barnes, Bennett, Millay, and Loy are at work - a legacy of social activism and formal innovation. This project celebrates the 
experiments and contributions of these women, attesting to the lasting value of their performative writing and art. 


\section{Works Cited}

Aimone, Joseph. “Millay’s Big Book, or the Feminist Formalist as Modern.” Unmanning

Modernism: Gendered Re-readings. Eds. Elizabeth Jane Harrison and Shirley Peterson.

Knoxville: U of Tennessee P, 1997.

Allen, Carolyn. "Djuna Barnes: Looking Like a Lesbian/Poet.” The Modern Woman Revisited:

Paris Between the Wars. New Brunswick: Rutgers UP, 2003.

Altieri, Charles. 'How the 'New Modernist Studies' Fails the Old Modernism.” Textual Practice 26.4 (2012): 763-782.

Ardis, Ann and Leslie W. Lewis, eds. Women's Experience of Modernity: 1875-1945. Baltimore: Johns Hopkins UP, 2003.

Aristotle. Poetics. Trans. George Whalley. Eds. John Baxter and Patrick Atherton. Montreal: McGill-Queens UP, 1997.

Atkins, Elizabeth. Edna St. Vincent Millay and Her Times. Chicago: U of Chicago P, 1936. Print.

Austin, J. L. How to Do Things with Words. Cambridge, MA: Harvard UP, 1962.

Ayers, David. Modernism: A Short Introduction. Malden, MA: Blackwell, 2004.

Barash, David P. Approaches to Peace: A Reader in Peace Studies. $3^{\text {rd }}$ ed. New York: Oxford UP, 2013.

Barnes, Djuna. "How it Feels to Be Forcibly Fed.” New York World Magazine. 6 September 1914. Djuna Barnes's New York. ed. Douglas Messerli. Los Angeles: Sun and Moon Press, 1989. 180-184.

—. "My Adventures Being Rescued." New York World Magazine. 15 November 1914. Djuna Barnes's New York. ed. Douglas Messerli. Los Angeles: Sun and Moon Press, 1989. 190-197. 
—. "My Sisters and I at a New York Prizefight." New York World Magazine. 23 August 1914. Djuna Barnes's New York. ed. Douglas Messerli. Los Angeles: Sun and Moon Press, 1989. 174-179.

-. Nightwood. New York: New Dimensions, 2006.

-. "Seventy Trained Suffragists Turned Loose on the City." Brooklyn Daily Eagle. 23

September 1913. Djuna Barnes's New York. ed. Douglas Messerli. Los Angeles: Sun and Moon Press, 1989. 69-72.

-. "When the Puppets Come to Town." The Morning Telegraph. 8 July 1917.

Bell, John. American Puppet Modernism: Essays on the Material World in Performance. New York: Palgrave MacMillan, 2008.

Benet, William Rose. "Harlem.” Theatre Arts Magazine 10 (October 1926).

Bennett, Chad. "Ladies' Voices Give Pleasure: Gossip, Drama, and Gertrude Stein.” Modern Drama 53 (2010): 311-331.

Bennett, Gwendolyn. "Heritage." Opportunity: A Journal of Negro Life 1 (December 1923): 371.

—. "The Ebony Flute.” Opportunity: A Journal of Negro Life 4 (August 1926): 260-261.

-. "The Ebony Flute.” Opportunity 4 (September 1926): 292-293.

-. "The Ebony Flute.” Opportunity 4 (October 1926): 322-323.

-. "The Ebony Flute." Opportunity 4 (November 1926): 356-358.

-. "The Ebony Flute." Opportunity 5 (March 1927): 90-91.

-. "The Ebony Flute." Opportunity 5 (April 1927): 122-123.

-. "The Ebony Flute." Opportunity 5 (June 1927): 182-183.

-. "The Ebony Flute." Opportunity 5 (August 1927): 242-243.

-. "The Ebony Flute." Opportunity 5 (October 1927): 308-309. 
-. "The Ebony Flute." Opportunity 5 (November 1927): 339-340.

-. "The Ebony Flute." Opportunity 6 (May 1928): 153.

Biers, Katherine. "Djuna Barnes Makes a Specialty of Crime: Violence and the Visual in her Early Journalism.” Women's Experience of Modernity: 1875-1945. Eds. Ann L. Ardis and Leslie W. Lewis. Baltimore: Johns Hopkins UP, 2003.

Black, Cheryl. The Women of Provincetown: 1915-1922. Tuscaloosa: U of Alabama P, 2001. Bombaci, Nancy. "'Well of Course, I Used to be Absolutely Gorgeous, Dear': The Female Interviewer as Subject/Object in Djuna Barnes's Journalism.” Criticism 44.2 (2002): 161-185.

Brecht, Bertolt. "Theatre for Pleasure or Theatre for Instruction.” 1935-1936. Trans. John Willet. Modern Drama. Vol. 1. Ed. William Worthen. Fort Worth, TX: Harcourt College, 1994. Print.

Broe, Mary Lynn. Silence and Power: A Re-Evaluation of Djuna Barnes. Carbondale: Southern Illinois University Press, 1991.

Burke, Carolyn. Becoming Modern: The Life of Mina Loy. New York: Farrar, Straus, and Giroux, 1996.

Butler, Judith. Bodies that Matter: On the Discursive Limits of Sex. New York: Routledge, 1993. -. Gender Trouble: Feminism and the Subversion of Identity. New York: Routledge, 2006.

Caselli, Daniela. Improper Modernism: Djuna Barnes's Bewildering Corpus. Farnham: Ashgate, 2009.

Chaney, Michael. "Traveling Harlem's Europe: Vagabondage from Slave Narratives to Gwendolyn Bennett's 'Wedding Day' and Claude McKay's Banjo"' Journal of Narrative Theory 32.1 (Winter 2002): 52-76. 
Chodorow, Nancy. The Reproduction of Mothering: Psychoanalysis and the Sociology of Gender. Berkeley: University of California Press, 1978.

Cixous, Helene. "Laugh of the Medusa." The Norton Anthology of Theory and Criticism. Ed. Vincent B. Leitch. New York: W.W. Norton and Company, 2001.

Clampitt, Amy. "Two Cheers for Prettiness.” A Review of Edna St. Vincent Millay, Selected Poems. Ed. Colin Falck. New Republic 6 and 12 (January 1992).

Claycomb, Ryan. Lives in Play: Autobiography and Biography on the Feminist Stage. Ann Arbor: University of Michigan Press, 2012.

Conover, Roger, ed. The Lost Lunar Baedeker: Poems of Mina Loy. New York: Farrar, Straus, and Giroux, 1996.

Conquergood, Dwight. "Performance Studies: Interventions and Radical Research.” The Performance Studies Reader. Ed. Henry Bial. London: Routledge, 2004.

Cotsell, Michael. The Theater of Trauma: American Modernist Drama and the Psychological Struggle for the American Mind, 1900-1930. New York: Peter Lang, 2005. Print.

D’Agata, John. The Next American Essay. St. Paul, MN: Graywolf, 2003.

-. University of Pittsburgh. Frick Fine Arts Building, Pittsburgh PA. 27 September 2011. Guest lecture.

De Certeau, Michel. "The Arts of Dying: Celibatory Machines." Heterologies: Discourse on the Other. Trans. Brian Massumi. Minneapolis: University of Minnesota Press, 1986.

Denning, Michael. The Cultural Front: The Laboring of American Culture in the Twentieth Century. New York, Verso, 1996.

Diamond, Elin. Unmaking Mimesis: Essays on Feminism and Theater. New York: Routledge, 1997. 
Dolan, Jill. "Performance, Utopia, and the 'Utopian Performative."” Theatre Journal 53.3 (2001): 455-479.

DuPlessis, Rachel Blau. "'Seismic Orgasm': Sexual Intercourse and Narrative Meaning in Mina Loy." Mina Loy: Woman and Poet. Eds. Maeera Shreiber and Keith Tuma. Orono, MI: The National Poetry Foundation, 1998.

-. "The Pink Guitar." Artifice and Indeterminacy: An Anthology of New Poetics. Ed. Christopher Beach. Tuscaloosa: University of Alabama Press, 1998. 297-318. Edwards, Brent Hayes. The Practice of Diaspora: Literature, Translation, and the Rise of Black Internationalism. Cambridge: Harvard University Press, 2003.

Elam, Harry J. and David Krasner. African American Performance and Theater History: A Critical Reader. New York, Oxford UP, 2001.

Ernest, John. "Representing Chaos: William Craft's 'Running a Thousand Miles for Freedom."” PMLA 121 (2006): 469-483.

Fahy, Thomas. "'I cannot live without a macaroon!': Food, Hunger, and the Dangers of Modern American Culture in Edna St. Vincent Millay's Aria da Capo.” Modern Drama 54.1 (2011): 1-21. Print.

Fernald, Anne E. "Women's Fiction, New Modernist Studies, and Feminism." Modern Fiction Studies 59.2 (2013): 229-240.

Fields, Kenneth. "The Poetry of Mina Loy." Southern Review 3 (July 1967): 597-607.

Foucault, Michel. The Archaeology of Knowledge. Trans. A. M. Sheridan Smith. New York: Pantheon, 1972. Print.

Frost, Elisabeth. “Mina Loy's 'Mongrel' Poetics.” Mina Loy: Woman and Poet. Eds. Maeera Shreiber and Keith Tuma. Orono, MI: The National Poetry Foundation, 1998. 
Garcia, Claire Oberon. "Black Women Writers, Modernism, and Paris.” International Journal of Francophone Studies 14.1 (2011): 27-42.

Gilmore, Leigh. Autobiographics: A Feminist Theory of Women's Self-Representation. Ithaca: Cornell UP, 1994.

Goeser, Caroline. Picturing the New Negro: Harlem Renaissance Print Culture and Modern Black Identity. Lawrence: University Press of Kansas, 2007.

Goody, Alex. “Auto/Biography / Auto-mythology: Mina Loy’s Anglo-Mongrels and the Rose. Representing Lives: Women and Auto/Biography. Eds. Alison Donnell and Pauline Polkey. New York: St. Martin's Press, 2000.

-. "Empire, Motherhood, and the Poetics of the Self in Mina Loy's Anglo-Mongrels." Life Writing 6.1 (April 2009): 61-77.

Govan, Sandra Y. “A Blend of Voices: Composite Narrative Strategies in Biographical Reconstruction." Recovered Writers/Recovered Texts: Race, Class and Gender in Black Women's Literature. Ed. Dolan Hubbard. Knoxville: U of Tennessee P, 1997.

—. "After the Renaissance: Gwendolyn Bennett and the WPA Years." MAWA Review 3.2 (1988): 27-31.

—. "Kindred Spirits and Sympathetic Souls: Langston Hughes and Gwendolyn Bennett in the Harlem Renaissance.” Langston Hughes: The Man, His Art, and His Continuing Influence. New York: Garland Publishing, 1995.

Green, Barbara. "Spectacular Confessions: 'How It Feels to Be Forcibly Fed."” Review of Contemporary Fiction 13.3 (1993): 70-88.

Green, Martin and John Swan. The Triumph of Pierrot. New York: Macmillan, 1986. Print. 
Grobbel, Michaela M. Enacting Past and Present: The Memory Theaters of Djuna Barnes, Ingeborg Bachmann, and Marguerite Duras. New York: Lexington Books, 2004. Hatt, Michael. "Race, Ritual, and Responsibility: Performativity and the Southern Lynching." Performing the Body, Performing the Text. Eds. Amelia Jones and Andrew Stephenson. New York: Routledge, 1999.

Hendrix, Jenny. "Odd Corners around Brooklyn” The Paris Review online. 2 April 2012.

Herring, Philip. Djuna: The Life and Work of Djuna Barnes. New York: Viking, 1995.

Hurston, Zora Neale. “Characteristics of Negro Expression.” Signifyin(g), Sanctifyin', and Slam Dunking: A Reader in African American Expressive Culture. Ed. Gena Dagel Caponi. Amherst: University of Massachusetts Press, 1999.

Irigaray, Luce. This Sex which is not One. Trans. Catherine Porter and Carolyn Burke. New York: Cornell UP, 1985.

Jameson, Fredric. The Political Unconscious: Narrative as a Socially Symbolic Act. Ithaca: Cornell UP, 1981.

Johnson, Charles S. Opportunity: A Journal of Negro Life (January 1923).

Johnson, Abby A. and Ronald M. Johnson. Propaganda and Aesthetics: The Literary Politics of Afro-American Magazines in the Twentieth Century. Amherst: U of Massachusetts P, 1979.

Kaiser, Jo Ellen Green. "Displaced Modernism: Millay and the Triumph of Sentimentality." Millay at 100: A Critical Reappraisal. Ed. Diane P. Freedman. Carbondale: Southern Illinois UP, 1995.

Kannenstein, Louis. The Art of Djuna Barnes: Duality and Damnation. New York: New York UP, 1977. 
King, Andrew David. “The Lessons of Objects: An Interview with Mark Doty.” 12 Dec. 2012. The Kenyon Review blog. Kenyon College. 8 Oct. 2014. Online.

Kouidis, Virginia M. Mina Loy: Modernist Poet. Baton Rouge: Louisiana State UP, 1980.

Krasner, David. A Beautiful Pageant: African American Theatre, Drama, and Performance in the Harlem Renaissance, 1910-1927. New York: Palgrave MacMillan, 2002.

Kristeva, Julia. Desire in Language: A Semiotic Approach to Literature and Art. Eds. Leon S. Roudiez and Alice Jardine. New York: Columbia UP, 1980.

Langley, Jerry and Sandra Govan. "Gwendolyn Bennett: The Richest Colors on her Palette, Beauty and Truth.” International Review of African-American Art 23 (2010): 6-15.

Levine, Nancy J. “'Bringing Milkshakes to Bulldogs': The Early Journalism of Djuna Barnes." Silence and Power: A Reevaluation of Djuna Barnes. Ed. Mary Lynn Broe. Carbondale: Southern Illinois University Press, 1991.

Loncraine, Rebecca. “Voix-de-Ville: Djuna Barnes' Stunt Journalism. Harry Houdini, and the Birth of Cinema.” Women: A Cultural Review 19.2 (2008): 156-171.

Loy, Mina. “Anglo-Mongrels and the Rose.” The Last Lunar Baedeker. Ed. Roger Conover. Highlands: The Jargon Society, 1982.

—. "Feminist Manifesto." The Lost Lunar Baedeker. Ed. Roger Conover. New York: Farrar, Strauss, and Giroux, 1996. 153-156.

—. "Modern Poetry." The Lost Lunar Baedeker. Ed. Roger Conover. New York: Farrar, Strauss, and Giroux, 1996. 157-161.

—. "Parturition." The Lost Lunar Baedeker. Ed. Roger Conover. New York: Farrar, Strauss, and Giroux, 1996. 4-8 
-. "Songs to Joannes." The Lost Lunar Baedeker. Ed. Roger Conover. New York: Farrar, Strauss, and Giroux, 1996. 53-70.

Lewis, Earl. "To Turn as on a Pivot: Writing Americans into a History of Overlapping Diasporas.” American Historical Review 100 (June 1995): 765-787.

Lott, Tommy. "Black Cultural Politics: An Interview with Paul Gilroy.” Found Object 4 (Fall 1994): 56-57.

Lust, Annette. From the Greek Mimes to Marcel Marceau and Beyond, Mimes, Actors, Pierrots, and Clowns: A Chronicle of the Many Visages of Mime in the Theater. Lanham, MD: Scarecrow, 2000. Print.

Lyon, Janet. "Mina Loy's Pregnant Pauses: The Space of Possibility in the Florence Writings." Mina Loy: Woman and Poet. Eds. Maeera Shreiber and Keith Tuma. Orono, MI: The National Poetry Foundation, 1998.

Mao, Douglas and Rebecca L. Walkowitz. "The New Modernist Studies.” PMLA 123.3 (2008): 737-748.

McHenry, Elizabeth. Forgotten Readers: Recovering the Lost History of African American Literary Societies. Durham: Duke UP, 2002.

McKee, Mary J. “Millay’s Aria da Capo: Form and Meaning." Modern Drama 9.2 (1966): 165169. Print.

Messerli, Douglas. Djuna Barnes's New York. Los Angeles: Sun and Moon Press, 1989. Michailidou, Artemis. “Gender, Body, and Feminine Performance: Edna St. Vincent Millay’s Impact on Anne Sexton," Feminist Review 78 (2004): 117-140. Print.

-. "Edna Millay, Muriel Rukeyser, and Adrienne Rich: Political Poetry, Social Protest, and the Place of the Woman Writer." EJAC 22 (2003): 7-22. Print. 
Milford, Nancy. Savage Beauty: The Life of Edna St. Vincent Millay. New York: Random House, 2001. Print.

Millay, Edna St. Vincent. Aria da Capo. Women Writers of the Provincetown Players: A Collection of Short Works. Ed. Judith E. Barlow. Albany: State University of New York Press, 2009. 261-282. Print.

-. "Author's Note.” Aria da Capo. Project Gutenberg Ebook. http://www.gutenberg.org/files/5790/5790-h/5790-h.htm. 8 Jan. 2014. Online.

Miller, Carolyn R. “Genre as Social Action.” Quarterly Journal of Speech 70 (1984): 151-167.

Miller, Cristanne. Cultures of Modernism: Marianne Moore, Mina Loy, and Else LaskerSchuler. Ann Arbor: University of Michigan Press, 2005.

Miller, J. Hillis. "Narrative.” Critical Terms for Literary Study. Eds. Frank Lentricchia and Thomas McLaughlin. Chicago: U of Chicago P, 1990.

Miller, John Hawkins. “'Temple and Sewer': Childbirth, Prudery, and Victoria Regina." The Victorian Family: Structure and Stresses. Wohl, Anthony S., ed. New York: St. Martin's, 1978.

Miller, Nina. Making Love Modern: The Intimate Public Worlds of New York's Literary Women. New York: Oxford UP, 1999.

Miller, Tyrus. "Beyond Rescue: Djuna Barnes." Late Modernism: Politics, Fiction, and the Arts Between the World Wars. Berkeley: University of California Press, 1999.

-. Late Modernism: Politics, Fiction, and the Arts Between the World Wars. Berkeley: U of California P, 1999.

Mitchell, Koritha. Living With Lynching: African American Lynching Plays, Performance, and Citizenship, 1890-1930. Urbana: University of Chicago Press, 2011. 
Murphy, Brenda. The Provincetown Players and the Culture of Modernity. New York: Cambridge UP, 2005. Print.

Nicholls, Peter. "Modernism and the Limits of Lyric." The Lyric Poem: Formations and Transformations. Ed. Marion Thain. New York: Cambridge UP, 2013. 177-194.

Nunning, Ansgar and Roy Sommer. "Diegetic and Mimetic Narrativity: Some Further Steps toward a Narrativity of Drama." Narratologia: Theorizing Narrativity. Eds. John Pier and Jose Angel Garcia Landa. Berlin: Walter de Gruyter GmbH \& Co., 2008. 331-354. Print.

Pankhurst, E. Sylvia. The Suffrage Movement: An Intimate Account of Persons and Ideals. New York: Longman's, Green, and Co., 1931.

Parker, Andrew and Eve Kosofsky Sedgwick, eds. Performativity and Performance. New York: Routledge, 1995.

Parmar, Sandeep. Reading Mina Loy's Autobiographies: The Myth of the Modern Woman. New York: Bloomsbury Academic, 2013.

Pelias, Ronald J. "Performative Writing as Scholarship: An Apology, an Argument, an Anecdote.” EDRS Opinion Papers (1998): 1-20.

Peppis, Paul. "Rewriting Sex: Mina Loy, Marie Stopes, and Sexology.” Modernism/Modernity 9.4 (2002): 561-579.

Perloff, Marjorie. "English as a 'Second' Language: Mina Loy's Anglo-Mongrels and the Rose." Mina Loy: Woman and Poet. Eds. Maeera Shreiber and Keith Tuma. Orono, MI: The National Poetry Foundation, 1998.

Phelan, Peggy. Mourning Sex: Performing Public Memories. New York: Routledge, 1997. -. Unmarked: The Politics of Performance. New York: Routledge, 1993. 
Pollock, Della. "Performing Writing." The Ends of Performance. Eds. Peggy Phelan and Jill Lane. New York: New York UP, 1998. 73-103.

Pound, Ezra. Literary Essays of Ezra Pound. New York: New Directions, 1968.

Puchner, Martin. Stage Fright: Modernism, Anti-Theatricality, and Drama. Baltimore: Johns Hopkins UP, 2002. Print.

Rexroth, Kenneth. "Les Lauriers Sont Coupés: Mina Loy." Circle 1.4 (1944): 69-72.

Rhodes, James. "Fighting for 'Respectability': Media Representations of the White, 'Working-Class,' Male Boxing 'Hero.'” Journal of Sport and Social Issues 35.4 (2011): 350-376.

Rich, Adrienne. Of Woman Born: Motherhood as Experience and Institution. New York: Norton, 1986.

Salih, Sara. "On Judith Butler and Performativity.” Sexualities and Communication in Everyday Life: A Reader. New York: Sage Publications, 2006. 55-67.

Schaum, Melita. "'Moon-flowers Out of Muck': Mina Loy and the Female Autobiographical Epic.” Massachusetts Studies in English 10.4 (Fall 1986): 254-76.

"Scholar Discovers the Only Known Painting of the Harlem Renaissance's Gwendolyn Bennett" Journal of Blacks in Higher Education (9 November 2012) www.jhbe.com.

Scuriatti, Laura. "Bodies of Discomfort: Mina Loy, the Futurists, and Feminism in Italy between the Wars." Women in Europe between the Wars. Eds. Angela Kershaw and Angela Kimyongur. Burlington: Ashgate, 2007. 131-141.

Sheffield, Rob. "Mina Loy in Too Much Too Soon: Poetry/Celebrity/Sexuality/Modernity." Literary Review: An International Journal of Contemporary Writing 46.4 (Summer 2003): 625-635. 
Sheldon, Sayre P. Her War Story: Twentieth Century Women Write about War. Carbondale: Southern Illinois UP, 1999.

Smith, Sidonie and Julia Watson, eds. Interfaces: Women/Autobiography/Image/Performance. Ann Arbor: University of Michigan Press, 2002.

Smith, William Gardner. "Ethel Waters.” Speech and Power. Ed. Gerald Early. New York: Ecco, 1992. 291-297.

Spahr, Juliana. Spiderwasp or Literary Criticism. Berkeley, CA: Explosive Books, 1998. Stavney, Anne. “'Mothers of Tomorrow': The New Negro Renaissance and the Politics of Maternal Representation.” African American Review 32 (1998): 533-561.

Tickner, Lisa. The Spectacle of Women: Imagery of the Suffrage Campaign, 1907-1914. Chicago: University of Chicago Press, 1988.

Tillis, Steve. Toward an Aesthetics of the Puppet: Puppetry as a Theatrical Art. New York, Greenwood Press, 1992.

Tuma, Keith. "Mina Loy's Anglo-Mongrels and the Rose." Mina Loy: Woman and Poet. Eds. Maeera Shreiber and Keith Tuma. Orono, MI: The National Poetry Foundation, 1998. Van Durme, Debora. “Conjuring Melodies from Arid Air: Mina Loy and Pound's Melopoeia.” The Cambridge Quarterly 37.3 (2008): 324-348.

Walker, Cheryl. Masks Sentimental and Austere: Culture, Psyche and Persona in Modern Women Poets. Bloomington: Indiana UP, 1991.

Watson, Steven. The Harlem Renaissance: Hub of African-American Culture, 1920-1930. New York: Pantheon, 1995.

Wetzsteon, Ross. Republic of Dreams, Greenwich Village: The American Bohemia, 1910-1960. New York: Simon \& Schuster, 2002. Print. 
Wheeler, Belinda. “Gwendolyn Bennett's 'The Ebony Flute.”’ PMLA 128.3 (May 2013): 744755.

Williams, Jeffrey. “The New Belletrism.” Style 33.3 (1999): 414-442.

Williams, Raymond. Modern Tragedy. Stanford: Stanford UP, 1966. Print.

Wilson, James F. Bulldaggers, Pansies, and Chocolate Babies: Performance, Race, and Sexuality in the Harlem Renaissance. Ann Arbor: University of Michigan Press, 2010.

Wilson, Sondra Kathryn, ed. The Opportunity Reader. New York: The Modern Library, 1999.

Wittig, Monique. "One is not Born a Woman." The Norton Anthology of Theory and Criticism.

Ed. Vincent B. Leitch. New York: W.W. Norton \& Company: 2001. 2014-2021.

Wolfe, Tom. The New Journalism. New York: Harper and Row, 1973.

Woollcott, Alexander. "Second Thoughts on First Nights: There are War Plays and War Plays." New York Times 14 Dec. 1919, sec. 8:2. Rpt. in Critical Essays on Edna St. Vincent Millay. Ed. William B. Thesing. New York: G. K. Hall, 1993. 39-43. Print. Zajko, Vanda and Miriam Leonard. Laughing with Medusa: Classical Myth and Feminist Thought. New York: Oxford UP, 2008. 